Portland State University

PDXScholar

\title{
Root-enhanced Infiltration in Stormwater Bioretention Facilities in Portland, Oregon
}

Ted David Hart

Portland State University

Follow this and additional works at: https://pdxscholar.library.pdx.edu/open_access_etds

Part of the Water Resource Management Commons Let us know how access to this document benefits you.

\section{Recommended Citation}

Hart, Ted David, "Root-enhanced Infiltration in Stormwater Bioretention Facilities in Portland, Oregon" (2017). Dissertations and Theses. Paper 3468.

https://doi.org/10.15760/etd.5352

This Dissertation is brought to you for free and open access. It has been accepted for inclusion in Dissertations and Theses by an authorized administrator of PDXScholar. Please contact us if we can make this document more accessible: pdxscholar@pdx.edu. 
Root-enhanced Infiltration in Stormwater Bioretention Facilities

in Portland, Oregon

by

Ted David Hart

A dissertation submitted in partial fulfillment of the requirements for the degree of

Doctor of Philosophy

in

Environmental Sciences and Resources

Dissertation Committee:

John A. Yeakley, Chair

Joseph Maser

Shane Latimer

Todd Rosenstiel

Portland State University

2017 
(C) 2017 Ted David Hart 


\begin{abstract}
I evaluated the effectiveness of plant roots to increase infiltration rates within stormwater bioretention facilities (SBFs), roadside planter compartments that filter stormwater. SBFs attenuate harmful effects of stormwater by reducing peak flow and retaining pollutants, with increased infiltration that improves both these functions. Researchers have shown that roots can increase infiltration within greenhouse, lab, field, and test SBF settings. However, no researchers have yet measured either the extent to which different root characteristics can increase infiltration or the variation in root characteristics and their effect on infiltration rates among plant assemblages within currently functioning SBFs.

To determine if root-enhanced infiltration was occurring within SBFs, I hypothesized

1) there is a relationship between root characteristics and infiltration during late spring, and 2) seasonal root growth increases infiltration rates. Within Portland, OR, I measured infiltration rate from January 2014 to February 2015 and root characteristics from JanuaryFebruary (J-F) and May-June (M-J) 2014 in ten SBFs with "Elk Blue" rush (Juncus patens) and 1 or 2 trees of less than $8.4 \mathrm{~cm}$ stem diameter. During M-J, four root characteristics showed a positive relationship with infiltration rate, and two root characteristics showed a strong positive relationship with infiltration rate within the topsoil. Also, a relationship was shown between the increase (J-F to M-J 2014) in three root characteristics and the increase in infiltration rate.
\end{abstract}


To determine if root morphology and infiltration rates differed among SBFs with two different dominant vegetation taxa (small and large root biomass), I hypothesized 3) Juncus patens and tree dominant assemblage (greater root biomass) exhibits greater infiltration compared to the Carex dominant assemblage, 4) the increase in infiltration rate and root characteristics from J-F to M-J is greater in the Juncus compared to the Carex assemblage, and 5) root surface area density (RSAD) within Juncus SBFs shows a positive relationship with infiltration rate in late spring. I measured infiltration rate from January 2014 to February 2015 and root characteristics from January-February (J-F) and May-June (M-J) 2014 among five large-root (Juncus and tree) and five small-root biomass (Carex sp) SBFs. Juncus SBFs showed greater values for three root characteristics during J-F and five root characteristics during M-J 2014 compared to Carex SBFs. Also, Juncus SBFs showed an increase from J-F to M-J 2014 for five root characteristics while Carex SBFs showed no root increase. Juncus SBFs showed a relationship with four root characteristics and Carex SBFs a showed relationship with one root characteristic and infiltration rate.

This work strongly suggests plant roots increase infiltration, and thus the primary functions of SBFs. Different root characteristics appear to increase infiltration rate at different depths. Data also show larger-root biomass plants increase infiltration rate to a greater degree than smaller-root biomass plants.

I recommend considering several site and facility characteristics when determining the potential for root-enhanced infiltration. When selecting plant species to enhance infiltration, I recommend using several criteria, determining root characteristic 
values at certain depths, considering installation approaches, and accounting for regional climate changes. 


\section{Acknowledgements}

I would like to thank my advisor, Dr. Alan Yeakley, for the all the support including the numerous words of wisdom, use of his lab space for my office and root processing and analysis, use of his computers for hydrological analysis, help modeling, and numerous other contributions over the past several years. I would like to also thank Dr. Joseph Maser for his guidance and help in developing my research during the first years of my degree. He was always a steadfast and understanding supporter. I would like to thank Dr. Todd Rosenstiel for steering me in the direction of in situ root and infiltration measurements as this has greatly increased my knowledge of bioretention facilities and my connections in this field. I would like to thank Dr. Shane Latimer who has always generously offered sage advice. He has provided a necessary real-word perspective to my research greatly enhancing its value. I would like to thank Dr. Martin LaFrenz who helped me during the initial phase of my dissertation project.

I would like to thank Josh Caplan who provided valuable assistance and advice analyzing roots. Josh also provided numerous phone calls to determine the most scientifically rigorous and valuable methods for representing root characteristics.

I would like to thank all the City of Portland Bureau of Environmental Service (BES) personnel who supported this project: Henry Stevens, Tim Kurtz, Denis O’Brien, Jeff Tilton, and Jordan McCann.

I would like to thank all the technicians with whom I have worked and who helped me along the way. I am thankful that Liz Olney led the first investigation of root characteristics in Portland bioretention facilities. Alex Desroches was a supportive and 
enthusiastic friend and collected much data and I'm grateful for his help. Steven Murschel has been a stalwart coworker during times when I needed him most and I most grateful to him for that. Jonathan Hawkes provided much enthusiastic work. Mathew Przyborski was always a pleasant and eager person to work with. Chris Parker provided much good advice. I would like to thank the funding sources for this work: Urban Long-Term Research Area (ULTRA, NSF grant number \#0948983), Portland State University (PSU) Cascades to Coast GK12 Project (NSF grant number \#0948041), the City of Portland Bureau of Environmental Service (BES), and Portland State University. 


\section{Table of Contents}

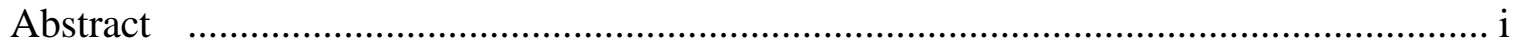

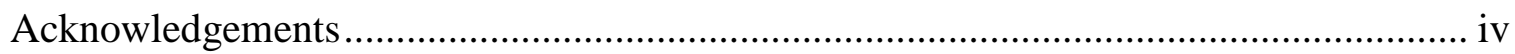

List of Tables ............................................................................................... viii

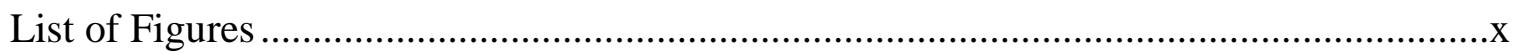

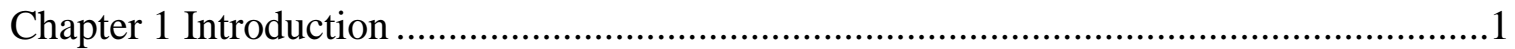

Chapter 2 Evidence for Root-enhanced Infiltration within in situ Stormwater Bioretention Facilities in Portland, OR ................................................... 17

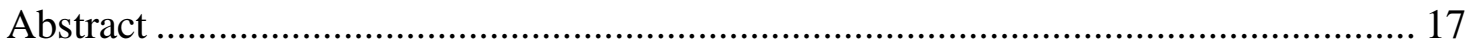

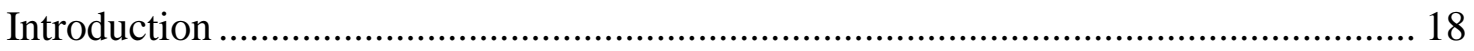

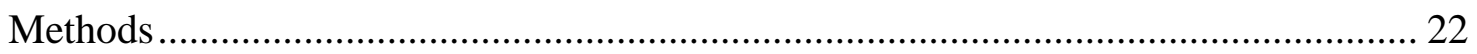

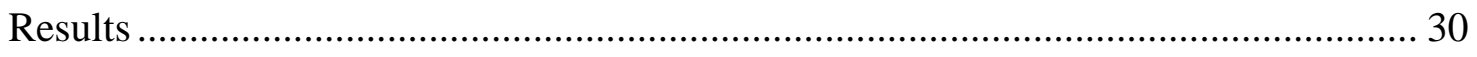

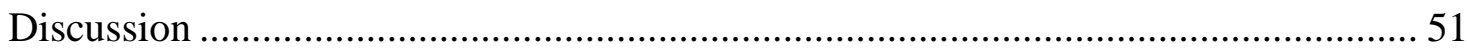

Chapter 3 Root Characteristics and Infiltration among Stormwater Bioretention Facilities with Different Vegetation Assemblages ....................................................60

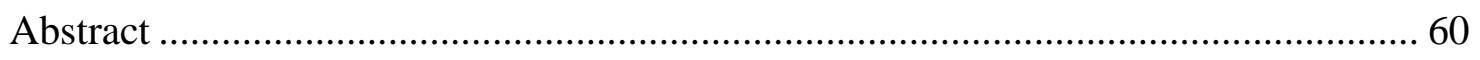

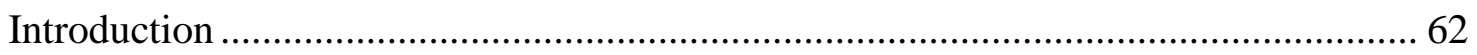

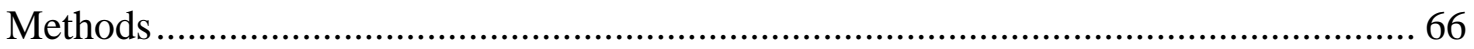

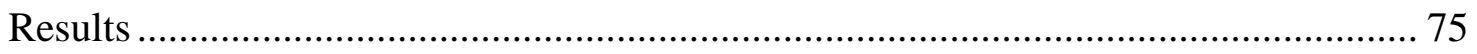

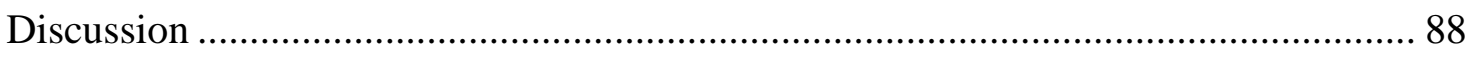

Chapter 4 Management Implications and Summary..............................................94

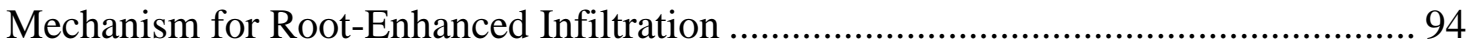

Potential for Root-enhanced Infiltration within SBFs............................................. 95

Selection and Installation of Vegetation for Root-enhanced Infiltration within SBFs . 99

Effect of Larger-root Versus Smaller-root Vegetation on Time to Infiltrate a Large

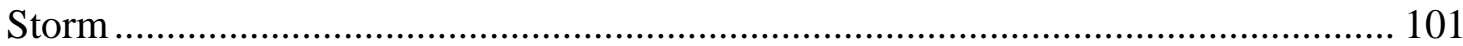

SBFs With and Without Vegetation .................................................................. 102

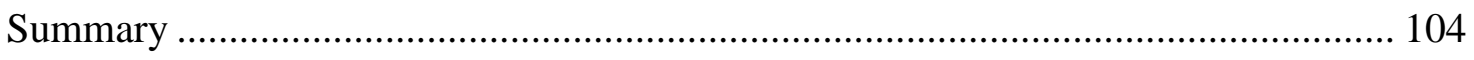


Appendices.

Appendix A: Criteria for selection of 10 Juncus stormwater bioretention facilities. These include installation, vegetation, root, soil, and other environmental characteristic categories. For each category averages, ranges, and associated citations are included.

Appendix B: Criteria for selection of five Juncus and five Carex stormwater bioretention facilities. These include installation, vegetation, root, soil, and other environmental characteristic categories. For each category averages, ranges, and associated citations are included.

Appendix C: Root mass density (RMD) depth distribution. *Significant difference in RMD between Juncus (top) and Carex (bottom) SBFs for J-F(left) and M-J (right). ${ }^{\mathrm{J}}$ Significant difference in RMD between J-F and M-J within Juncus SBFs.

Appendix D: Stormwater bioretention facility characteristics. "na" indicates not applicable.

Appendix E: Stormwater bioretention facility plant characteristics. "na" indicates not applicable.

Appendix F: Stormwater bioretention facility soil characteristics. 126

Appendix G: Infiltration rates (cm/hr) within stormwater bioretention facilities. "na" indicates when stormwater did not rise above surface of topsoil and thus no infiltration rates were measured. 


\section{List of Tables}

Table 1: Installation, vegetation, root, soil, and other environmental characteristics of selected stormwater bioretention facilities. Shown are characteristic averages, ranges, and associated citations.

Table 2: Root characteristics measured including abbreviation, term, and description. .. 29

Table 3: Root characteristic values and percent increase (gray boxes) from JanuaryFebruary to May-June 2014 at different depths. These include root mass density (RMD), root length density (RLD), root surface area density (RSAD), root diameter (RD), and root volume density (RVD). Dashed line indicates average division between topsoil and subsoil. Significant increase in root characteristics determined by using Wilcoxon rank sum test ( $\mathrm{p}$-value $<0.05)$...

Table 4: Stepwise regression of six root characteristics and infiltration rate during M-J. Root characteristics include root mass density (RMD) and root diameter (RD), and root volume density (RVD).

Table 5: Installation, vegetation, root, soil, and other environmental characteristics, ranges, and associated citations of selected stormwater bioretention facilities. 69

Table 6: Root characteristic values of Juncus and Carex SBFs during J-F and M-J 2014. Root characteristics include root mass density (RMD), length density (RLD), specific root length (SRL), root surface area density (RSAD), root diameter (RD), and root volume density (RVD). Dashed line indicates average depth of topsoil.

Table 7: Percent difference between Juncus and Carex SBFs among different root characteristics during J-F and M-J 2014. Positive values indicate greater Juncus root characteristics. Root characteristics include root mass density (RMD), length density (RLD), specific root length (SRL), root surface area density (RSAD), root diameter (RD), and root volume density (RVD). Significant difference in root characteristics determined using Wilcoxon rank sum test (pvalue $<0.05)$. NS indicates no significant difference. Dashed line indicates average depth of topsoil.

Table 8: Difference between the increase in Juncus and increase in Carex SBFs root characteristics from J-F to M-J 2014. Root characteristics include root mass density (RMD), length density (RLD), specific root length (SRL), root surface area density (RSAD), and root volume density (RVD). Shaded values indicate significant difference (Wilcoxon rank sum test, $\mathrm{p}$-value $<0.05$ ). NS indicates no significant difference. Dashed line indicates average depth of topsoil. 
Table 9: Root characteristic ranges for significant relationships (linear regression) found between Juncus or Carex (shaded) SBFs and infiltration rate during M-J 2014. Root characteristics include root mass density (RMD), length density (RLD), specific root length (SRL), root surface area density (RSAD), root diameter (RD), and root volume density (RVD). 


\section{List of Figures}

Figure 1: Curb extension bioswale in Portland, OR. ..................................................... 2

Figure 2: Stormwater flow through bioswale. ..................................................... 5

Figure 3: Location of 10 stormwater bioretention facilities in Portland, OR (Snyder 2008, Estimated depth to ground water and configuration of the water table in the Portland, OR).

Figure 4: Precipitation, ponding depth (circles and boxes) and infiltration rate (black lines) in two bioswales, time (hr:min, $\mathrm{x}$ axis), and area of infiltration measurement (dashed box) in SE Portland, OR.

Figure 5: Top graph: Monthly precipitation (bars), average monthly infiltration rate (line, $\mathrm{n}=10$ bioswales), and standard error of monthly infiltration rate (error bars) during 2014 (top). *Indicates significant increase or decrease in infiltration from one month to the next (Wilcoxon rank sum tests, p-value <0.05) during 2014 and 2015. Bottom graph: Average monthly precipitation (bars, $n=10$ years) and standard deviation (error bars) during 2004 to 2013. Precipitation data used were from HYDRA City of Portland Water gage network (USGS 2015).

Figure 6: J-F (top) and M-J (bottom) 2014 precipitation every 5 minutes (bars) and average weekly infiltration rates (circles) and standard error of weekly infiltration rates (error bars).

Figure 7: March to April 2014 precipitation every 5 minutes (bars) and average weekly infiltration rates (circles) and standard error of weekly infiltration rates (error bars)

Figure 8: Precipitation/event during J-F $(n=33)$ and M-J $(n=25)$ in 10 Juncus bioswales. P-value determined using Wilcoxon rank sum test.

Figure 9: Time per precipitation event during J-F ( $n=33)$ and M-J $(n=25)$ in 10 Juncus bioswales. P-value determined using Wilcoxon rank sum test.

Figure 10: Infiltration rate during J-F (A), Mar-Apr (B), M-J (C), July-Aug (D), Sept (E), Oct-Dec $2014(\mathrm{~F})$, and J-F $2015(\mathrm{G})$ in 10 Juncus bioswales. Text above bars (e.g. A, G) indicate significant difference with other months (Wilcoxon rank sum test). 
Figure 11: Root mass density (RMD) J-F (top) and M-J (bottom) by $8.5 \mathrm{~cm}$ depth increments. *Significant increase in RMD from J-F (top) to M-J (bottom) using a t-test (unequal variance, normal distribution). Each depth increments

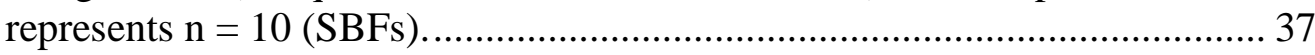

Figure 12: Root mass density within $1 \mathrm{~m}$ soil profile and infiltration rate during M-J 2014 within 10 bioswales in Portland, OR.

Figure 13: Root mass density within subsoil and topsoil and infiltration rate M-J 2014 within 10 bioswales in Portland, OR. 39

Figure 14: Root mass density (RMD) increase from J-F to M-J 2014 and infiltration rate increase from J-F to M-J 2014 in 10 Juncus SBFs.

Figure 15: Root diameter J-F (top) and M-J (bottom) by $8.5 \mathrm{~cm}$ depth increments. *Significant increase in root diameter from J-F (top) to M-J (bottom) using a t-test (unequal variance, normal distribution). Each depth increments represents $n=10(\mathrm{SBFs})$.

Figure 16: Ratio of topsoil to subsoil root diameter and infiltration rate during M-J 2014 within 10 bioswales in Portland, OR. 42

Figure 17: Root diameter within topsoil and infiltration rate during M-J 2014 within 10 bioswales in Portland, OR

Figure 18: Root diameter increase within the topsoil and infiltration rate increase (from JF to M-J 2014) within 10 bioswales in Portland, OR.

Figure 19: Root surface area density (RSAD) J-F (top) and M-J (bottom) by $8.5 \mathrm{~cm}$ depth increments. *Significant increase in RSAD from J-F (top) to M-J (bottom) using a t-test (unequal variance, normal distribution) and Wilcoxon rank sum test.

Figure 20: Root surface area density (RSAD) increase and infiltration rate increase (from J-F to M-J 2014) within 10 bioswales in Portland, OR. 45

Figure 21: Root volume density J-F (top) and M-J (bottom) by $8.5 \mathrm{~cm}$ depth increments. *Significant increase in root volume density from J-F (top) to M-J (bottom) using a t-test (unequal variance, normal distribution).

Figure 22: Root volume density $\left(\mathrm{cm}^{3} / \mathrm{cm}^{3}\right)$ within topsoil (0-50 $\mathrm{cm}$ depth) and infiltration rate during M-J 2014 within 10 bioswales in Portland, OR. 
Figure 23: Root length density (RLD) J-F (top) and M-J (bottom) by $8.5 \mathrm{~cm}$ depth increments. *Significant increase in RLD from J-F (top) to M-J (bottom) using a t-test (unequal variance, normal distribution) and Wilcoxon rank sum test.

Figure 24: Location of five larger-root biomass stormwater bioretention facilities (Juncus patens + Tree, dark green circles) and five smaller-root biomass stormwater bioretention facilities (Carex species, light yellow circles) in Portland, OR (Snyder 2008, estimated depth to ground water and configuration of the water table in the Portland, OR). 68

Figure 25: Precipitation, ponding depth (circles and boxes), and infiltration rate (black lines) in one Carex (triangles) and one Juncus (squares) bioswale in SE Portland, OR.

Figure 26: Monthly precipitation (bars), average monthly infiltration rate of Juncus (dark line) and Carex (light line) SBFs, and standard error (error bars). *Significant difference between Juncus and Carex infiltration rate for a given month ( $\mathrm{p}$ value $<0.05$, Wilcoxon rank sum test). $U$ indicates unequal variance between Juncus and Carex SBFs for a given month ( $\mathrm{F}$ test for unequal variance, $\mathrm{p}$ value $<0.05)$. $\mathrm{J}$ and $\mathrm{C}$ indicate significant infiltration difference between one month to the next for Juncus and Carex SBFs, respectively (Wilcoxon rank sum tests, $\mathrm{p}$-value $<0.05$ ).

Figure 27: Infiltration rate of five Juncus with Tree(s) and five Carex SBFs during J-F and M-J 2014, and the increase in infiltration rate from J-F to M-J 2014. The minimum (lowest infiltration rate measured), average, and maximum (highest infiltration rate measured) for the five Juncus and five Carex SBFs from Jan 2014 to Feb 2015. *Significant difference between Juncus and Carex infiltration rates (Wilcoxon rank sum test).

Figure 28: Root mass density (RMD; $1 \mathrm{~m}$ profile) and infiltration rate during M-J 2014 within five Juncus bioswales in Portland, OR.

Figure 29: Ratio of subsoil to topsoil root mass density (RMD) and infiltration rate during M-J 2014 within five Juncus bioswales in Portland, OR.

Figure 30: Root mass density (RMD) increase and infiltration rate increase from J-F to M-J 2014 within 5 Juncus bioswales in Portland, OR.

Figure 31: Root diameter (RD) within the topsoil and infiltration rate during M-J 2014 within five Juncus bioswales in Portland, OR. 
Figure 32: Root surface area density (RSAD) within five Juncus (subsoil: topsoil) and five Carex (1 $\mathrm{m}$ profile) SBFs and infiltration rate during M-J 2014 in Portland, OR.

Figure 33: Root volume density (RVD) within the topsoil and infiltration rate during M-J 2014 within five Juncus bioswales in Portland, OR.

Figure 34: M-J 2014 precipitation every 5 minutes (bars) and average weekly infiltration rates for five Juncus (circles) and five Carex (triangles) bioswales with standard error of weekly infiltration rates (error bars). *Significantly greater infiltration rate within Juncus compared to Carex bioswales. 


\section{Chapter 1}

\section{Introduction}

The Urban Setting: Urban growth continues to increase impervious surface area (ISA, Homer et al. 2015). Most of the world's population now live in cities (de Sherbiniin et al. 2009) and, by $2050,90 \%$ of the U.S. population is expected to live in urban areas. Within 20 U.S. cities, the average ISA growth rate is 0.31 percent/year (Nowak and Greenfield 2012) with most of this increase in transportation land use (Schueler 1994). ISA growth results in greater urban stormwater runoff (Scheyer and Hipple 2005), which is one of the largest sources of pollution and flooding in most cities (Burton and Pitt 2002). Stormwater runoff adversely impacts surface water quality in two general ways: introduction of nonpoint source pollutants and altering of the hydrological cycle (Yeakley et al. 2014). These include flood damage, reduced water quality, and degraded and destroyed aquatic and terrestrial habitats (Barnes et al. 2002).

Bioretention Facilities: In response primarily to flooding and water quality threats, stormwater bioretention facilities (SBFs) have become one of the most frequently used storm-water management tools (Davis et al. 2009) as they successfully attenuate flooding and water quality threats (Moore 2011) and help meet state and federal stormwater regulatory requirements (Kloss et al. 2006). Their use is encouraged by U.S. federal and state agencies (EPA 1999, 2007, 2009, ORDEQ 2016). SBFs are a type of green stormwater infrastructure (GSI), best management practice (BMP), and low impact 
development (LID) (Fig. 1). In 1972, the United States

Environmental Protection Agency (USEPA) introduced the National Pollutant Discharge Elimination System (NPDES) permits and Total Maximum Daily Load (TMDL)

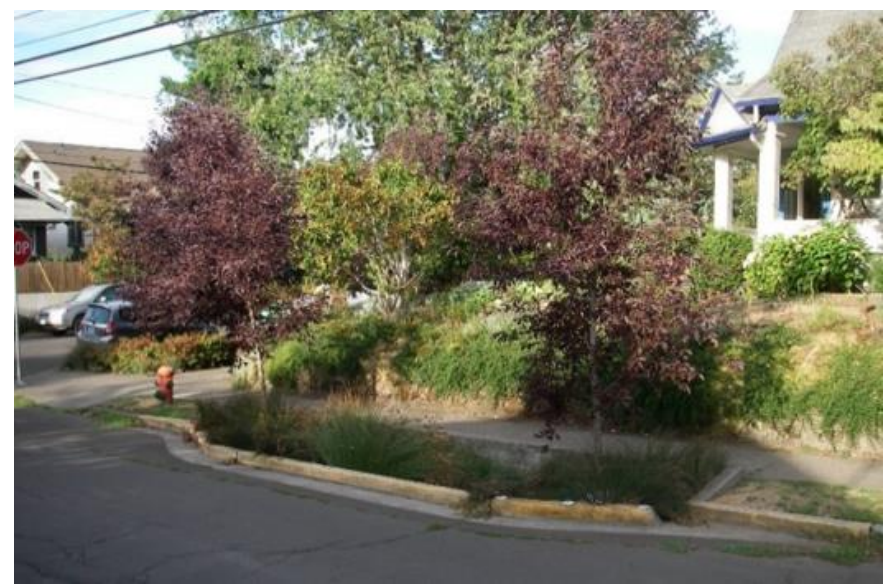

Figure 1: Curb extension bioswale in Portland, OR. regulations in an effort to limit stormwater pollutant and flow discharge to receiving water bodies (EPA 1999). SBFs were first developed in the early 1990s by Prince George's County, Maryland, primarily to attenuate stormwater quality and flooding threats (Coffman et al. 1994). Since then, SBFs have become one of the most frequently used storm-water management tools in urbanized watersheds (Davis et al. 2009). This is mainly because traditional mitigation efforts largely fail to adequately improve water quantity and quality threats as they have focused on end-of-pipe solutions (Kloss et al. 2006). The U.S. EPA has continued to encourage their use as they help meet NPDES regulatory requirements, are applicable almost everywhere in the U.S., have few limitations (EPA 2012), can be added incrementally (Kloss et al. 2006), recharge groundwater (EPA 2016a), and are relatively inexpensive (EPA 2007, Garmestani et al. 2012, Houle et al. 2013).

Bioretention within the Pacific Northwest: Oregon and Washington State have both increased their use of SBFs. In Oregon, many municipalities have a Phase I or Phase II (population less than 100,000) MS4 (municipal separate stormwater sewer system, 
EPA 2016b) permit as part of the NPDES program. Some of these municipalities have developed stormwater management plans requiring new developments and redevelopments to implement LID where feasible (ORDEQ 2016). As part of Portland's MS4 permit, new development and redevelopment projects that create or replace greater than $500 \mathrm{ft}^{2}\left(46.5 \mathrm{~m}^{2}\right)$ of impervious surface must prioritize and include implementation of LID/green stormwater infrastructure (GSI) or equivalent design and construction approaches for managing stormwater pollutant and runoff control. Portland now has over 2,000 public SBFs. Washington State is currently developing requirements for installing LID, or green stormwater infrastructure, for new construction and redevelopment in many cities and counties (WADOE 2016). An August 2008 ruling from the State of Washington's Pollution Control Hearing represented the first decision in the USA to require LID implementation in new developments to meet NPDES Phase I stormwater permit requirements (Yeakley and Dunham 2014). In Seattle, WA, untreated highway run-off has been shown to be lethal to adult Coho salmon (Oncorhynchus kisutch) relative to unexposed controls (Spromberg et al. 2016). However, when the same runoff was flowed through SBF media and then into tanks with adult Coho no mortality occurred, highlighting the water quality benefit SBFs provide to receiving water bodies.

Bioretention Function: SBFs are built to maximize two primary functions: to lower peak flow and/or volume reduction (attenuate flooding) and to capture pollutants (lower pollutants flowing to receiving water bodies). They consist of small excavated areas which are backfilled with a topsoil mixture designed to optimize infiltration/groundwater recharge, pollutant retention, and vegetative growth. SBFs are 
typically covered with native wetland vegetation. The topsoil mixture is typically a highpermeable sandy loam with organic matter. Flood and drought tolerant vegetation are used ranging from small plants to medium-sized trees. An inlet structure routes polluted urban runoff from the surrounding ISA to the unit. Sometimes an overflow structure is installed to lower extended periods of flooding ( $>2$ days, Roy-Poirier et al. 2010). This study investigates bioswales within inner Southeast Portland, which are a common type of Portland bioretention facility. Such bioswales infiltrate water into the subsoil (no bottom liner), contain wetland vegetation, and are moderately sized (approximately 16 $\left.\mathrm{m}^{2}\right)$

Bioretention Infiltration: Primary functions of infiltrating SBFs with no bottom liner are most strongly controlled by infiltration rate of the subsoil (Pitt et al. 2002). In general, subsoil characteristics that affect infiltration include: texture (Saxton and Rawls 2006), bulk density

(Massman and Butchart 2001), soil organic matter (Olson et al. 2013), temperature (Dingman 2014), and soil moisture content (Nassif and Wilson 1975). Texture is typically the most useful (Saxton and Rawls 2006) and often an accurate indicator of infiltration (Clapp and Hornberger 1978) in test SBFs (Selbig and Balster 2009). Bulk density has been shown to affect infiltration in an inconsistent manner among urban lawns (Hamilton and Waddington 1999) and riparian buffer types (i.e. Acer saccharinum, Bharati et al. 2002). Within urban soils, infiltration reduction from soil compaction is most significant in soils with higher clay fractions (Pitt et al. 2008). Brown and Hunt (2010) showed how the rake method of excavation, previous to bioretention installation, 
tended to yield more permeable, less compacted soils than the scoop method in three soil types: sand, loamy sand, and clay. Organic matter generally increases infiltration through development of stable soil aggregates and provides food and habitat for soil biota, such as earthworms, with both organic matter and earthworms increasing pore space (Greene 2008). Emerson and Traver (2008) found that a temperature increase of 0 to $38^{\circ} \mathrm{C}$ corresponded to a decrease in dynamic viscosity $(\mu)$ of approximately $163 \%$ and resulted in a hydraulic conductivity increase from 0.5 to 1.0 $\mathrm{cm} / \mathrm{hr}$. Nassif and Wilson (1975) demonstrated in lab experiments how an increase in soil moisture generally decreases infiltration rate with various ground cover and slopes. Triplett et al. (1968) showed the formation of macropores in shrinking silty clay loam soil after a dry period (low soil moisture), and a subsequent increase in infiltration rate.

The infiltration process is typically broken into two separate, though not necessarily distinct, parts. The initial infiltration rate into a dry soil, which

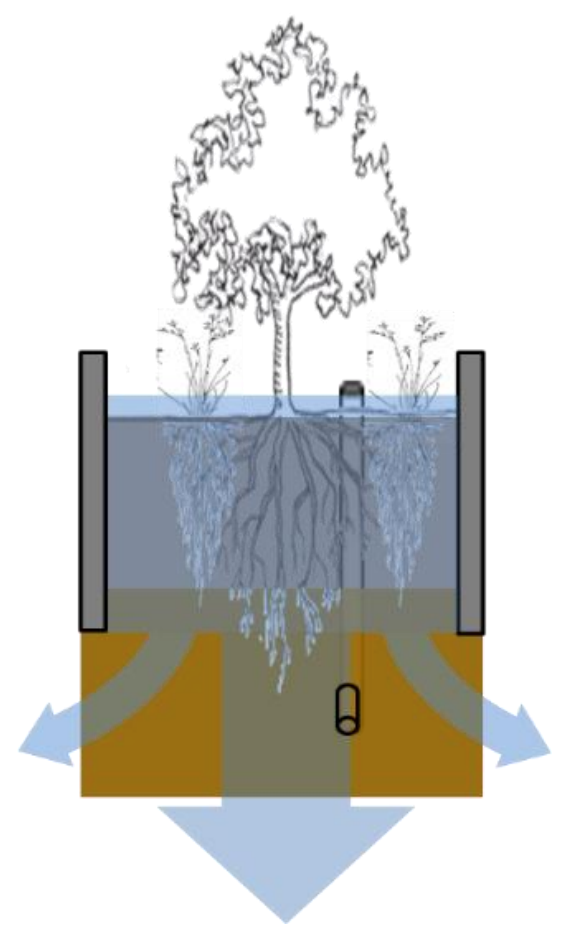

Figure 2: Stormwater flow through bioswale. commonly has macropores (NRCS 2012), tends to be higher than wet soils and is dominated by high matric suction or tension head (Dingman 2014). As the infiltration process proceeds and the soil becomes increasingly wet, matric suction become increasingly smaller and the infiltration rate slows to a steady rate (Emerson and Traver 2008). Once the soil is near saturation, infiltration rate is driven primarily by gravimetric 
forces and is "practically equal to the saturated hydraulic conductivity" (Hillel 1998). The infiltration rate at this point is based on how fast water can move through the most restrictive layer, such as a subsoil layer of higher bulk density and percent fines (NRCS 2012).

Infiltration within SBFs with no bottom liner (Fig. 2), is analogous to the function of a single-ring infiltrometer with the following assumptions: subsoil is homogeneous and isotropic (hydraulic conductivity same in all directions), soils behind the wetting front are saturated, and Darcy's law (flux) is appropriate,

$$
q=-\mathrm{K} \frac{d \mathrm{~h}}{d \mathrm{l}}
$$

where $\mathrm{q}=$ flow per unit area (infiltration rate, length/time), $\mathrm{K}$ = hydraulic conductivity, 1 $=$ flow path length, and $\mathrm{h}=$ hydraulic head. Single ring infiltrometers are circular while most SBFs are rectangular; also, single ring infiltrometers are much smaller than a typical bioswale. Nevertheless, infiltration rates for square and circular ring devices have been shown to be similar (Bagarello et al. 2016). As SBFs are typically $>0.8 \mathrm{~m}$ in diameter (wide), edge effects along the concrete sides and variability of infiltration measurements are likely low to negligible (Lai and Ren 2007).

Bulk Density and Texture Effects on Root Growth: Coarse-textured soils commonly impede roots at higher bulk densities than fine-textured soils (Daddow and Warrington 1983). Also, there is a strong positive relationship between bulk densities at which roots are impeded and average pore radius, ranging from 0.02 (clay) to 0.2 (Loamy sand) $\mathrm{mm}$ in diameter (Daddow and Warrington 1983). Roots of most plant species are severely impeded at field capacity when bulk density exceeds 1.4 (clay), 1.55 (clay loam 
and loam), 1.65 (silt loams), 1.80 (fine sandy loams), and 1.85 (loamy fine sands) $\mathrm{g} / \mathrm{cm}^{3}$ (Bowen 1981).

However, some plant species show healthy root growth in soils above the bulk density and texture values mentioned above. Bartens et al. (2008) showed healthy tree root growth (Quercus velutina and Acer rubrum) within clay subsoil of $1.63 \mathrm{~g} / \mathrm{cm}^{3}$. Place (2006) found 55\% of Palmer amaranth (Amarnanthus palmeri) roots penetrated into loamy sand subsoil at $1.9 \mathrm{~g} / \mathrm{cm}^{3}$. These species likely optimize three common plant responses to root impedance: 1) a decrease in turgor pressure in the region of elongation slowing the extension of the root cap (Atwell 1990), 2) an increase in radial turgor pressure immediately behind the root tip increasing root diameter (Materechera et al. 1991, Clark et al. 2003), and 3) lateral root proliferation (Gregory 2006). Among hormones, auxin and gibberellins have been shown to directly increase root growth (Gregory 2006), and ethylene has been suggested as playing a key role in mediating an increase in root diameter and a decrease in elongation rate (Clark et al. 2003), while brassinolides have been shown to inhibit root growth (Chaiwanon and Wang 2015).

Soil Moisture Effects on Root Growth: Within initially dry soil, an increase in soil moisture reduces the structural rigidity soil allowing for greater root growth, particularly in flood tolerant plants. Day et al. (2000) showed that silver maple (Acer saccharinum) roots can grow in moderately compacted soil with high soil water content, whereas flowering dogwood (Cornus florida L.) is unable to take advantage of this opportunity. Bartens et al. (2009) showed shorter inundation periods for green ash (Fraxinus pennsylvanica) and swamp white oak (Quercus bicolor) always resulted in greater root 
depth. In contrast, no difference in root depth was found in one species of Atlantic whitecedar (Chamaecyparis thyoides) between two contrasting hydroperiods, intermittent and persistent flooding (Rodgers et al. 2003).

As soil becomes saturated with water, lower oxygen may start to limit root growth (Kirkegaard et al. 1992). Most plants likely experience harmful effects to their fine roots after two days of inundation (Bartens et al. 2009). However, several mostly wetland species have been observed to experience no to little effect ranging from 2-14 days of waterlogging (Gregory 2006). Bartens et al. (2009) observed that allowing for an inundation time of less than 48 hours with flood tolerant species was sufficient for normal root distribution, with greater flood periods severely restricted root depth. Two similar Polygonum species (persicaria and cespitosum) showed different responses to flooding with persicaria maintaining high growth rates, particularly near the surface, while cespitosum showed similar distribution but significantly lower growth (Bell and Sultan 1999). Different plant species' ability to acclimate to waterlogging appears to strongly relate to their ability to form aerenchyma tissue. This tissue is commonly observed in wetland vegetation and can form within less than 24 hours (Gregory 2006). Of the plant species studied here, aerenchyma tissue formation has been observed in black tupelo (Nyssa sylvatica, Keeley 1979), leprechaun ash (Fraxinus pennsylvanica, Gomes and Kozlowski 1980), and tufted hair grass (Deschampsia cespitosa, Packham et al. 1992). Thus far studies have not investigated the presence of aerenchyma formation within the two dominant ground cover plant assemblages within this study (Juncus patens, Carex testacea and dolichostachya). Although similar species such as Juncus effusus (Visser 
and Bögemann 2006) and other Carex sp. (Visser et al. 2000) have shown aerenchyma tissue formation.

Root Infiltration Mechanisms: Several root-associated mechanisms (Ghestem et al. 2011) can greatly increase macropore/preferential flow (pore diameter $>0.3 \mathrm{~mm}$, Jarvis 2007). Roots provide preferential water flow along live or dead root pathways (Reubens et al. 2007, Bartens et al. 2008) creating a hydraulic (i.e. wet) linkage between root and soil. During growth, roots release various organic and inorganic substances into the soil (Hawes et al. 2000) which can increase aggregate stability (Martens 2002) creating larger pore size/macropores and thus greater infiltration (Lado et al. 2004). These exudates also create acidic conditions within the rhizosphere, mobilizing soil nutrients, which in turn increases microbial action, effectively breaking down the soil and further creating macropores (Gregory 2006). As the diameter of roots often exceeds the lower limit of macropore diameter (diameter $\sim 0.3 \mathrm{~mm}$, Jarvis 2007), relatively large tunnels are created when roots die (Hodge et al., 2009). Diurnal swelling and shrinkage of root diameter (Huck et al. 1970, Ghestem et al. 2011), enlarging of soil cracks (Gregory 2006), and seasonal root loss (Black et al. 1998) further create macropores (Archer et al. 2002).

Root-Enhanced Infiltration Literature: Roots have been shown to increase infiltration within laboratories (Nassif and Wilson 1975, Bratieres et al. 2008), greenhouses (Bartens et al. 2008), crops (Bharati et al. 2002), and natural areas (Thompson et al. 2010) during different seasons (Meek et a. 1992). In greenhouses, Bartens et al. (2008) and Day et al. (2000) showed that different tree species had similar 
tap root distribution that dramatically increased infiltration compared to bare ground controls, penetrating compact subsoils (bulk density $1.6 \mathrm{~g} / \mathrm{cm}^{3}$ ). Bartens et al. (2008) showed a relationship with root mass density (root mass per soil volume, RMD) and hydraulic conductivity. They also showed trees (Quercus velutina and Acer rubrum) increased infiltration by an average of $63 \%$ versus no vegetation, primarily during May and July. Devitt and Smith (2002) showed that water penetrated more deeply in vegetated field plots versus non-vegetated controls in the fall. Among studies, the root characteristic shown to have the strongest relationship is root surface area density (RSAD, root surface area per unit soil volume, Gregory 2006) being linearly correlated with average infiltration rate (Zhou and Shangguan 2007) and runoff (Zhou and Shangguan 2008). Within silty clay fields of alfalfa (Medicago saliva) in California, Mitchel et al. (1995) attributed an infiltration increase from $0.13 \mathrm{~cm} / \mathrm{hr}$ in May to $0.32 \mathrm{~cm} / \mathrm{hr}$ in October to macropores created from decaying tap roots. Rasse et al. (2000) showed alfalfa root systems increased soil porosity and infiltration rates in alfalfa treatments compared to bare soil treatments in July using a mini-rhizotron in western Michigan. Meek et al. (1992) found roots contributed to infiltration during May $(7.9 \mathrm{~cm} / \mathrm{hr})$ and Oct $(9.5 \mathrm{~cm} / \mathrm{hr})$ within Alfalfa (Medicago sativa) sandy loam fields. Bharati (2002) found that the average 60 min cumulative infiltration was five times greater under vegetation buffers than under cultivated fields and pastures. Thompson et al. (2010) found the enhancement of infiltration capacity in the presence of vegetation is documented to a greater extent within in arid ecosystems compared to areas that receive more rainfall. However, 
researchers have yet to characterize root characteristics, seasonal variability, and the extent root characteristics can increase infiltration within currently functioning SBFs. Theoretical Root-enhanced Infiltration: Theoretically, roots may increase the infiltration rate within SBFs. Within saturated media, Darcy's Law (Eq. 1) shows that hydraulic conductivity ( $\mathrm{K}$, soil's ability to transmit water, length/time) has a large effect on infiltration rate. Change in hydraulic head is indicated by $d$ h and $d$ l represents the flow path length. K can be determined by particle size analysis (Odong 2013) with the most generalized formula developed by Vukovic and Soro (1992)

$$
K=\frac{g}{v} \times \mathrm{C} \times \mathrm{f}(\mathrm{n}) \times d_{e}^{2}
$$

where $\mathrm{K}$ = hydraulic conductivity; $\mathrm{g}=$ acceleration due to gravity; $\mathrm{v}=$ kinematic viscosity; $C=$ sorting coefficient $f(n)=$ porosity function, and $d_{e}=$ effective grain diameter $\left(D_{10}\right) . D_{10}$ is the soil particle diameter at $10 \%$ of the cumulative particle size distribution. Particle size distribution of soil and root diameter distribution can be similarly measured. The best match for Portland SBF root distribution found in this work (root diameter range of 0.2-9.8 mm, uniformity range of 1.2-4.4, and effective grain size ( $\left.\mathrm{D}_{10}\right)$ range of $0.2-0.9 \mathrm{~mm}$ ) is with the Hazen formula (Carrier 2003). This formula is appropriate for fine sand $(0.0025 \mathrm{~mm})$ to gravel (64 mm diameter), uniformity coefficient $(U)<5$, and an effective grain size of 0.1 to $3 \mathrm{~mm}$ :

$$
K=\frac{g}{v} \times 6 \times 10^{-4}[1+10(\mathrm{n}-0.26)] d_{10}^{2}
$$


where $\mathrm{g}=$ acceleration due to gravity; $v=$ kinematic viscosity; and $\mathrm{d}_{10}=$ effective grain diameter $\left(\mathrm{D}_{10}\right)$. Porosity $(\mathrm{n})$ may be derived from the empirical relationship with the uniformity coefficient $(U)$ :

$$
n=0.2551\left(1+0.83^{U}\right)
$$

where $\mathrm{U}$ is given by:

$$
U=\left(\frac{d_{60}}{d_{10}}\right)
$$

Typically, the soil particle diameter at $10 \%$ and $60 \%$ of the cumulative particle size distribution ( $d_{10}$ and $d_{60}$, respectively) are used to determine $U$. Instead, the root diameter at $10 \%$ and $60 \%$ of the cumulative distribution could be measured and used to determine the uniformity coefficient $(U)$ to calculate $\mathrm{K}$.

Applying Preliminary Data to Theoretical Root-enhanced Infiltration: I used Portland SBF root data from preliminary investigations (below) to determine infiltration rate along roots. Using equation 5, I calculated a $d_{10}$ of $0.64 \mathrm{~mm}, d_{60}$ of 1.1 , and $U$ of 1.8 . Using equation 4 and $U$ of 1.8 , I calculated porosity $(n)$ as $0.44(44 \%)$. Using equation 3 , I then calculated hydraulic conductivity $(\mathrm{K})$ as $40 \mathrm{~cm} / \mathrm{min}$. Using equation 1 , a $\mathrm{K}$ of 40 $\mathrm{cm} / \mathrm{min}$, a $d \mathrm{~h}$ of $10 \mathrm{~cm}$ (typical ponding depth in Portland SBF), and a $d 1100 \mathrm{~cm}(45 \mathrm{~cm}$ of topsoil and $55 \mathrm{~cm}$ subsoil), I calculated a $q$ (infiltration rate) of $4.0 \mathrm{~cm} / \mathrm{min}$ or 240 $\mathrm{cm} / \mathrm{hr}$.

The $\mathrm{K}$ value of $40 \mathrm{~cm} / \mathrm{min}$ determined above is much greater than the $\mathrm{K}$ reported (Dingman 2014) for average topsoil (sandy loam) of $0.2 \mathrm{~cm} / \mathrm{min}$ and average subsoil (loam) of $0.04 \mathrm{~cm} / \mathrm{min}$ for the soils typical of Portland SBFs. Also, the infiltration rate of 
$240 \mathrm{~cm} / \mathrm{hr}$ determined above is much greater than the range measured in Portland SBFs $(0.3-20.3 \mathrm{~cm} / \mathrm{hr})$. However, this greater infiltration rate would only exist around the roots, and wetland plant roots typically only occupy $1-5 \%$ of the volume of the soil within the extent of the root distribution (Hillel 2007). It is possible that this infiltration rate could be applied to as much as 58\% of the root volume, however, as Gill and Jackson (2000) have shown this value to be an average root turnover rate for temperate wetland plants.

Preliminary Investigations: To determine if Portland SBFs and environmental characteristics were suitable for root-enhanced infiltration, several short investigations were conducted over several years. Olney et al. (2010) found differences in root depth and density among four commonly used Portland SBFs species (Juncus patens, J. patens "Elks Blue", Carex dolichostachya, and Liriope muscari). She found greatest root mass density between 5 and $10 \mathrm{~cm}$ deep for all species, and concluded that the native subsoil did not appear to be a significant barrier to root growth, with some individual plants penetrated $66 \mathrm{~cm}$ of subsoil (112 cm total depth). Bohren et al. (2012) found an average and a maximum bulk density of 1.4 and $1.6 \mathrm{~g} / \mathrm{cm}^{3}$, respectively, and an average loam texture (37\% sand, $42 \%$ silt, $22 \%$ clay) within the subsoil (3ft depth) under Portland SBFs $(n=40)$. These bulk density values are below levels considered to impede roots for silt loam soils $\left(1.65 \mathrm{~g} / \mathrm{cm}^{3}\right)$ and clay loam $\left(1.55 \mathrm{~g} / \mathrm{cm}^{3}\right.$, Bowen 1981). From February 2011 to June 2013, I found greater infiltration rates during spring and summer compared to winter using a water depth gage in one Portland SBF. Additionally, the large range in infiltration $(0.3-20.3 \mathrm{~cm} / \mathrm{hr})$ and root mass density $\left(0.03-2.0 \mathrm{~kg} / \mathrm{m}^{3}\right)$ values measured in SE Portland suggested the range of predictor values (roots) was large enough to capture a 
full range of response variable (infiltration) values (Gotelli and Ellison 2004). In addition, vegetation percent cover within Portland SBFs has been observed to peak in May and June (personal communication with Denis O’Brien) which likely corresponds with higher root growth (Gregory 2006). Lastly, dominant vegetation within Portland SBFs (e.g. Juncus patens) appears to be well adapted to the urban SBF environment withstanding up to 2-3 days of saturation during winter, growing vigorous in the spring, and tolerating low soil moisture conditions during long and dry summers (Bohren et al. 2012). This preliminary work suggested that Portland SBFs and environmental characteristics were suitable for root-enhanced infiltration and provided the necessary base line data to set up the following two experiments of this dissertation.

Even though hydraulic conductivity has a more direct physical relationship with root characteristics, I chose to use infiltration rate $(\mathrm{cm} / \mathrm{hr})$ in this work for the following reasons: 1) infiltration rate is more recognizable and understood by the general scientific community, 2) infiltration rate and hydraulic conductivity are both common within the literature, and 3) preliminary work showed infiltration rate had a stronger relationship to root characteristics compared to hydraulic conductivity.

Chapter 2: To determine if root-enhanced infiltration was occurring in SBFs, I selected 10 facilities within inner Southeast Portland where approximately 130 similar SBFs existed. These facilities were selected using several criteria, controlling for as many factors known to affect infiltration and root growth as possible. Roots were sampled and quantified during January to February (J-F) and May to June (M-J) 2014. Infiltration was 
measured using water depth gages during drawdown events after precipitation periods from Jan 2014 to Feb 2015. My hypotheses were:

1. Invariant to season, there is a relationship between root characteristics and infiltration rate during $\mathrm{J}-\mathrm{F}$ and $\mathrm{M}-\mathrm{J}$ periods.

2. Seasonal dynamics increase root characteristics and therefore infiltration rate.

Chapter 3: To determine if SBFs with a vegetation assemblage with larger root characteristics (e.g. root biomass) would exhibit greater infiltration than a vegetation assemblage with smaller root characteristics, I compared five larger-root facilities (Juncus patens dominant + tree) with five smaller-root facilities (Carex species dominant). I controlled for as many factors known to affect infiltration and root growth as possible. Roots were sampled and quantified during J-F and M-J 2014. Infiltration was measured using water depth gages during drawdown events after precipitation events from Jan 2014 to Feb 2015. My hypotheses were:

3. The Juncus + tree assemblage (greater root biomass) exhibits greater infiltration during J-F and M-J periods compared to the Carex assemblage.

4. The increase in root characteristics and infiltration rate from J-F to M-J is greater in the Juncus + tree assemblage compared to the Carex assemblage.

5. Root surface area density within Juncus + tree SBFs shows a positive relationship with infiltration rate in late spring. 
Chapter 4: The management implications of this work were highlighted as the use of SBFs continue to increase. These include environmental conditions well suited for rootenhanced infiltration, vegetation selection to increase root-enhanced infiltration, effect of larger versus smaller-size roots on time of ponding, SBF cost versus benefits, and mechanisms of root-enhanced infiltration.

The overarching aim of this research was to determine if root-enhanced infiltration was occurring in fully functioning SBFs, where environmental conditions were suitable for both healthy root growth and infiltration. This work also determined if dominant vegetation with greater root biomass would show a greater root-enhanced relationship compared to dominant vegetation with lower root biomass. This was intended to inform SBF managers about the role plant roots play in SBF infiltration, in the context of continued installation and increasing number of SBFs. This research was performed to improve our understanding of how environmental conditions, seasonal winter and spring root characteristics, and vegetation assemblage can influence infiltration processes. 


\title{
Chapter 2
}

\section{Evidence for Root-enhanced Infiltration}

\section{within in situ Stormwater Bioretention Facilities in Portland, OR}

\begin{abstract}
Stormwater bioretention facilities (SBFs) are used in urban areas to retain pollutants and minimize flooding. Both these functions depend on stormwater infiltrating into SBF substrates rapidly. While plant roots are known to increase stormwater infiltration within experimental SBFs, prior studies have not measured the extent to which roots increase infiltration within fully functional SBFs. In addition, greater infiltration in summer compared to winter has been observed in SBFs, but it is not clear how strongly different root characteristics and depth distributions influence this phenomenon. I hypothesized that: 1) Invariant to season, there is a relationship between root morphological characteristics and infiltration rate during J-F and M-J periods, and 2) Seasonal growth dynamics increase root characteristics and therefore infiltration rate. I selected ten SBFs that were as similar as possible but spanned a large range of root biomass. Infiltration rates were recorded using water depth data loggers from January 2014 to February 2015. Root characteristics were measured to a depth of $1 \mathrm{~m}$ during January-February (J-F) and May-June (M-J) 2014. Generally, results suggest plant investment in root mass density (RMD), root surface area density (RSAD), root diameter (RD), and root volume density (RVD) increase infiltration rate in SBFs. Six root characteristics increased from J-F to M-J 2014: RMD, root length density (RLD), RSAD,
\end{abstract}


$\mathrm{RD}$, and RVD. Three root characteristics showed a positive relationship with infiltration rate during M-J 2014: RMD, RD, and RVD. Most of this root increase occurred at the 60$85 \mathrm{~cm}$ depths. Also, two root characteristics (RMD and RD) together showed a strong positive relationship with infiltration rate during M-J 2014. In addition, a seasonal infiltration rate was shown. A relationship between the increase (J-F to M-J 2014) in three root characteristics (RMD, RSAD, and RD) and the increase (J-F to M-J 2014) in infiltration was also shown. This work provides evidence of root-enhanced infiltration within fully functional SBFs. Thus, environmental characteristics such as soil root impedance, root characteristics and distribution, and projected root system size should be considered when selecting plants for SBFs.

\section{Introduction}

The widespread use and increasing number of stormwater bioretention facilities (SBFs) provide the opportunity to study in situ how plant roots may influence SBF performance. SBFs have become one of the most frequently used storm-water management tools (Davis et al. 2009), as they successfully attenuate flooding and water quality threats (Moore 2011). Also, traditional mitigation efforts (i.e., end-of-pipe solutions) sometimes fail to adequately improve water quantity and quality threats (Kloss et al. 2006, Yeakley et al. 2014) and are often more expensive (EPA 2007). The rapidly increasing number of SBFs highlights the importance of measuring and optimizing their performance. Infiltration rate determines both reduction in flooding and pollutant capture, 
and is thus an ideal measure of performance (Hunt et al. 2012). Currently in the Pacific Northwest, numbers of SBF are increasing and helping to lower peak flow within Portland, OR (BES 2014). In Seattle, research has also shown SBFs improve water quality benefits for organisms in receiving water bodies, such as Coho salmon (Oncorhynchus kisutch, Spromberg et al. 2016).

Root-enhanced infiltration has been demonstrated in test SBFs in a limited number of studies. Selbig and Balster (2009) showed that within rain gardens with similar soil conditions, turf grass (shallow roots) had a lower median infiltration $(0.7 \mathrm{~cm} / \mathrm{hr})$ than those planted with prairie species $(2.2 \mathrm{~cm} / \mathrm{hr}$, uniform root depth distribution). They also showed that infiltration rates were greater in spring (April and May) when root growth is typically greatest, and summer (June through August), for both precipitation gardens. Greene (2008) showed that plants and macrofuana greatly increased hydraulic conductivity and stormwater storage compared to controls in 10 small-sized test SBFs using lysimeters. Hatt et al. (2009) found significant increases in infiltration capacity coincided with vigorous vegetation growth during spring within field-scale biofiltration systems. However, the relationship between root characteristics and infiltration has yet to be evaluated in currently functioning SBFs (i.e. not test facilities).

Several root characteristics have been shown to increase infiltration at during different periods of the year. The distribution of roots with depth in the soil and root diameter (RD) are relatively easy to measure (Gregory 2006), correlate with many soil processes such as changes to porosity, and are commonly used (Lynch 1995). Zedler (2007) suggested a higher ratio of lower to upper root mass was a good predictor of 
infiltration. Specific root length (SRL, root length per root dry mass) is one of the most frequently measured morphological parameter of fine roots $(<2.0 \mathrm{~mm}$ diameter). SRL is believed to characterize economic aspects of the root system (e.g. carbon cost to produce length of root) and to indicate environmental changes (Ostonen et al. 2007). Root length density (RLD, root length per volume of soil) is a useful and widely accepted measure of all root sizes (Gregory 2006). Lange et al. (2009) found greater drainage with RLD from 1.1 to $1.5 \mathrm{~cm} / \mathrm{cm}^{3}$ among three tree species year-round. Infiltration rates have been observed to increase with greater legume (Trifolium sp.) root mass density (RMD, root mass per volume of soil) within fine sandy loam when rates were measured after root decomposition in fall (Disparte 1987). Bartens et al. (2009) showed that infiltration increased with root depth for green ash (Fraxinus pennsylvanica) and swamp white oak (Quercus bicolor) in spring and summer. Root surface area density (RSAD, root surface area per unit soil volume) has been shown to be linearly correlated with average infiltration rate in the summer (Zhou and Shangguan 2007) and runoff in the summer and fall (Zhou and Shangguan 2008) in ryegrass (Lolium perenne) within silty clay loam pots in a greenhouse.

Wetland field studies of temperate tree and Juncus species generally show a burst of root production in spring (De la Cruz and Hackney 1977) and/or summer (Fitter et al. 1998) and mortality in fall (Gregory 2006). Generally, root turnover, or percent of roots replaced annually, for temperate wetland species average 58\% globally for fine roots (0-5 mm diameter, gill and Jackson 2000). Within trees, typically strong root growth occurs in the spring, but these roots may live less than a month (Eissenstat and Yanai 1997). Root 
longevity within seasonal wet areas can be strongly linked to soil inundation time, where roots are depleted of oxygen (Eissenstat and Yanai 1997). Generally, perennial plants, such as Juncus species, show a flush of root growth in spring and significant mortality in the fall (Pregitzer et al. 2000). Fitter et al. (1998) showed root accumulation of Juncus squarrosus within an England, U.K., grassland was greater in the summer and largely a function of long growing seasons. De la Cruz and Hackney (1977) showed Juncus roemerianus root biomass within a Mississippi marsh peaked in April. They observed the belowground productivity was comparable with aboveground biomass growth reported in the literature. However, Wetzel and Howe (1999) showed very little seasonal root biomass change in Juncus effusus in an Alabama freshwater wetland.

Infiltration has similarly been shown to vary seasonally within SBFs in a limited number of studies. Over a two-year period, Emerson and Traver (2008) and Lewellyn et al. (2016) found greater infiltration in the summer than in the winter in a Pennsylvania grassy swale. Similarly, greater summer and lower winter infiltration rates have been observed in Portland, Oregon (Tim Kurtz, personal communication). Within one turf grass and one native prairie rain garden, infiltration rates were higher during spring and summer than fall and winter in Wisconsin (Selbig and Balster 2009).

I selected ten Portland SBFs using several criteria to control for as many variables as possible, measured the infiltration rate for 14 months, and measured root growth during J-F and M-J in 2014. I hypothesized that: 1) There is a relationship between root characteristics and infiltration rate during M-J, and 2) an increase in seasonal root growth increases infiltration rates. 


\section{Methods}

Inner southeast Portland, Oregon (Fig. 3), was selected for the study site as it contains approximately 130 SBFs with similar design, size, age, and environmental characteristics (e.g. subsoil bulk densities). Several criteria were used to select 10 SBFs with 1-2 trees and Juncus patens dominant vegetation (Table 1, Appendix A, Fig. 1). These ten SBFs were chosen with a large range in root mass density for Portland SBFs. This was done to increase the likelihood that a large range of infiltration values would also be measured and thus any root-infiltration relationship. No facilities were selected whose characteristics were found to limit root growth, such soil bulk density greater than $1.55 \mathrm{~g} / \mathrm{cm}^{3}$ for clay loam (Bowen 1981).

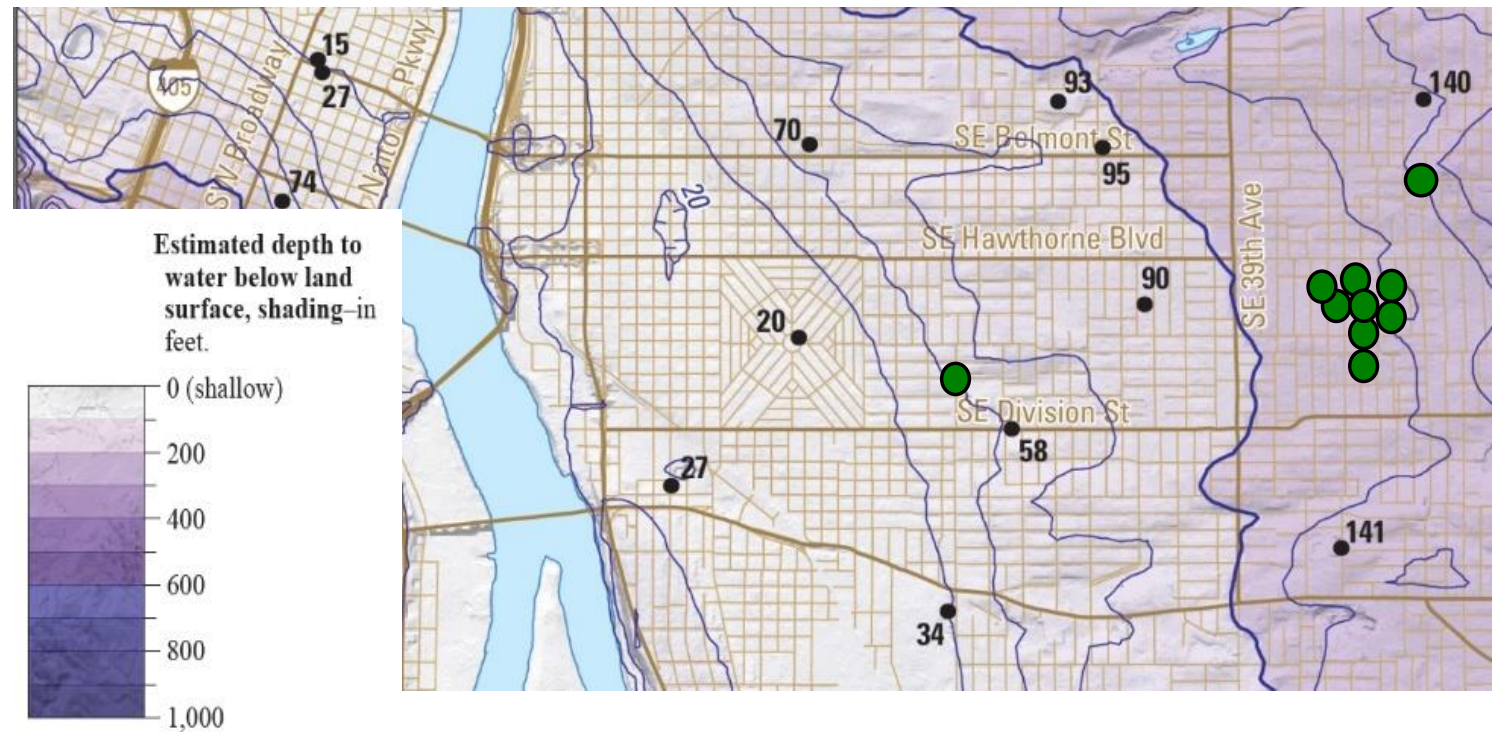

Figure 3: Location of 10 stormwater bioretention facilities in Portland, OR (Snyder 2008, Estimated depth to ground water and configuration of the water table in the Portland, OR). 
Infiltration Measurements: Water level was recorded in every facility from January $1^{\text {st }} 2014$ to February $28^{\text {th }} 2015$ using U20 water level HOBO data loggers (Onset Computer Corp., Bourne, MA). One data logger was installed in the approximate middle of each facility, approximately $10 \mathrm{~cm}$ below the subsoil within $3.2 \mathrm{~cm}$ diameter PVC tubes, and tubes were wrapped in cloth (grade 90 unbleached cheesecloth) to allow water through but not sand and silt. Tubes were secured to ground with stakes and hose clamps so data loggers would not move. Water depth was record at a five-minute interval for 75 days, at which time data were downloaded using a portable data shuttle and data loggers were reset.

Data logger depth measurements were validated by simulating a water quality design storm (0.83 in, NRCS Type 1A rainfall distribution) or larger design storm (1.89 in, 25-yr, 6-hr storm) depending on the infiltration capacity of the SBF. Nearby hydrants and a flow regulator were used to provide inflow to a depth greater than $7 \mathrm{~cm}$ and the actual infiltration rate (water depth using tape measure every 5 minutes) was compared with data logger values. 
Table 1: Installation, vegetation, root, soil, and other environmental characteristics of selected stormwater bioretention facilities. Shown are characteristic averages, ranges, and associated citations.

\begin{tabular}{|c|c|c|c|c|}
\hline Category & Criteria & Average & Range & Citation \\
\hline \multirow{5}{*}{$\begin{array}{l}\text { Facility } \\
\text { installation }\end{array}$} & $\begin{array}{l}\text { Facility size }<1 \text { standard deviation from mean of } \\
\text { inner SE Portland }\left(11-39 \mathrm{~m}^{2}, 31 \mathrm{~m}^{2}\right)\end{array}$ & $18.9 \mathrm{~m}^{2}$ & $12.4-26 \mathrm{~m}^{2}$ & Hart 2012 Unpublished data \\
\hline & Sizing: $6.5 \%$ Target, $2-15 \%$ Range & $6.6 \%$ & $4.4-10.3 \%$ & SWMM 2014, Stevens 2013 \\
\hline & (Sizing = Facility area $\%$ of catchment area) & & & \\
\hline & Facility age $>3$ years & $3.5 \mathrm{yrs}$ & 3.1-3.5 yrs & Selbig and Balster 2009 \\
\hline & 0-6\% Slope (\% rise/run) & $0.9 \%$ & $0.1-2.2 \%$ & SWMM 2014 \\
\hline \multirow[t]{4}{*}{ Vegetation } & Similar number plant species & 4.1 & 3-5 plant species & \\
\hline & $\begin{array}{l}\% \text { cover J. patens }<3 \text { standard deviations of mean } \\
\text { in inner SE Portland facilities }(0-62 \%, 16 \% \text { avg) }\end{array}$ & $50 \%$ & $37-60 \%$ & Hart 2012 Unpublished data \\
\hline & Large range in plant density (\# plants/facility area) & 2.8 & 1.9-3.6 plants $/ \mathrm{m}^{2}$ & \\
\hline & Large range in tree $\mathrm{DBH}$ & $6.3 \mathrm{~cm}$ & $3.6-8.4 \mathrm{~cm}$ & Leverett and Bertolette 2015 \\
\hline Roots & $\begin{array}{l}\text { Large range in root mass density and overlap with } \\
\text { similar studies }\end{array}$ & $0.7 \mathrm{~kg} / \mathrm{m}^{3}$ & $0.4-1.1 \mathrm{~kg} / \mathrm{m}^{3}$ & Bartens et al. 2009, Gregory 2006 \\
\hline \multirow[t]{2}{*}{ Topsoil } & $\begin{array}{l}\text { Bulk density }<3 \text { standard deviations of mean in } \\
\text { inner SE Portland range found in Portland } \\
\text { facilities }\left(0.7-1.5 \mathrm{~g} / \mathrm{cm}^{3}\right) \text { and below values } \\
\text { shown to inhibit root growth }\left(1.80 \mathrm{~g} / \mathrm{cm}^{3} \text { fine }\right. \\
\text { sandy loams) }\end{array}$ & 1.2 & $\begin{array}{l}1.1-1.5 \mathrm{~g} / \mathrm{cm}^{3} \\
\text { (Fine sandy loam) }\end{array}$ & $\begin{array}{l}\text { Bowen 1981, } \\
\text { Hart } 2012 \text { Unpublished data }\end{array}$ \\
\hline & $\begin{array}{l}\% \text { fines }<3 \text { standard deviations of mean } \% \text { fines } \\
\text { found in inner SE Portland }(0-85 \%, 34 \% \text { avg) }\end{array}$ & $38 \%$ & $35-49 \%$ & $\begin{array}{l}\text { Kalra and Maynard 2001, Hart } \\
2012 \text { Unpublished data }\end{array}$ \\
\hline Subsoil & $\begin{array}{l}\text { Bulk density }<3 \text { standard deviations of mean in } \\
\text { inner SE Portland facilities }\left(0.9-1.6 \mathrm{~g} / \mathrm{cm}^{3}\right) \text { and } \\
\text { below values shown to inhibit root growth (1.55 } \\
\mathrm{g} / \mathrm{cm}^{3} \text { clay loam) }\end{array}$ & 1.4 & $\begin{array}{l}1.1-1.55 \mathrm{~g} / \mathrm{cm}^{3} \\
\text { (Clay loam) }\end{array}$ & $\begin{array}{l}\text { Bowen 1981, } \\
\text { Hart } 2012 \text { Unpublished data }\end{array}$ \\
\hline & $\begin{array}{l}\% \text { fines }<3 \text { standard deviations found in inner SE } \\
\text { Portland facilities }(27-100 \%, 68 \% \text { avg) }\end{array}$ & $75 \%$ & $50-89 \%$ & $\begin{array}{l}\text { Kalra and Maynard 2001, Hart } \\
2012 \text { Unpublished data }\end{array}$ \\
\hline
\end{tabular}

Precipitation: To maximize the number of usable precipitation and infiltration events, a short minimum inter-event time (MIET, minimum number of dry minutes between separate precipitation events, Joo et al. 2014) was calculated. This was possible as the facility catchment sizes were small (Table 1, Appendix A), resulting in cessation of surface, or overland, flow typically 5-10 min after cessation of a precipitation event. Only the overland flow, as opposed to direct flow (direct flow $=$ overland flow + interflow, Eq. 6, Dingman 2014) was used to calculate MIET (Joo et al. 2014). It was assumed that 
interflow did not enter the facilities due to the concrete walls along the sides of the facilities and distance to groundwater (baseflow, Fig. 3, Table 1, Appendix A):

$$
\text { Runoff }=\text { Overland Flow }+ \text { Interflow }+ \text { Baseflow }
$$

MIET was calculated using day, time and precipitation amount from the Sunnyside rain gage located an average of approximately $600 \mathrm{~m}$ or 10 blocks to the 10 selected SBFs (HYDRA City of Portland Water gage network, USGS 2015). For each facility, time of precipitation cessation and time of last inflow (slow trickle) into the facility was recorded. The difference between these two times was calculated. This value was then rounded up to the next 5-minute interval (e.g. 18 rounded up to $20 \mathrm{~min}$ ). This was done to increase efficiency when determining precipitation event times and infiltration rates and to ensure very little/no inflow was occurring during infiltration measurements.

Infiltration Calculation: Infiltration rate was measured after each precipitation event that met the following criteria: 1) greater than $5 \mathrm{~cm}$ of ponding depth (stormwater surface in the SBF) at the start of the infiltration event, 2) >30 min from the end of the MIET to the start of next precipitation event, and 3) greater than $1 \mathrm{~cm}$ ponding depth at the end of the infiltration event (Fig. 4). For example, 30 min of infiltration data recorded at a 5-min interval allowed for 6 ponding depth data points. Infiltration rate was determined by calculating the slope of the best fit linear regression for the drawdown data (Emerson and Traver 2008, Selbig and Balster 2009). Only infiltration rate slopes with $\mathrm{R}^{2}>0.95$ were used to eliminate cases where extraneous inflow from other sources, such as a nearby car being washed, occurred. For all months measured, the average, minimum, and maximum infiltration rates were calculated. 


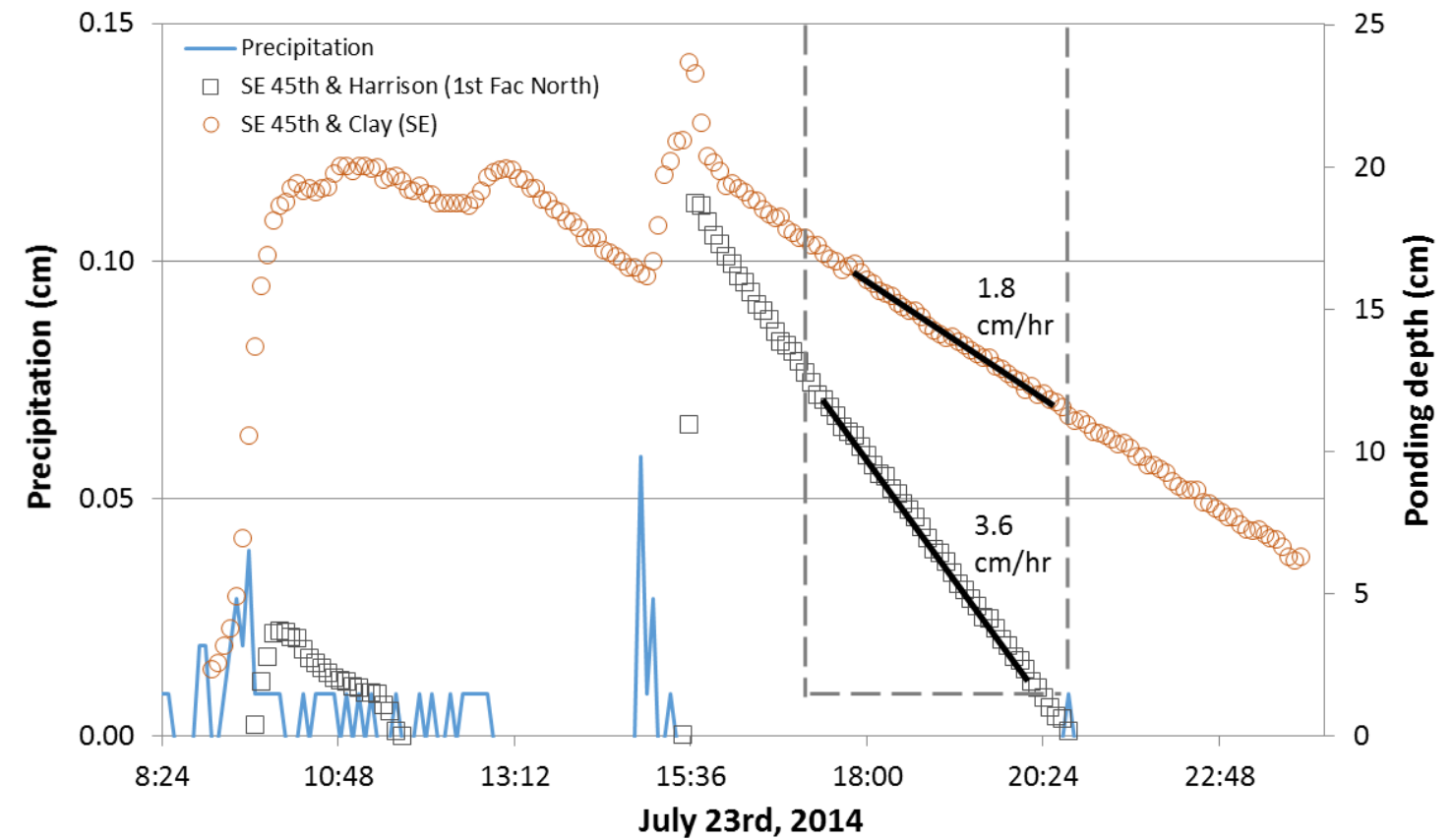

Figure 4: Precipitation, ponding depth (circles and boxes) and infiltration rate (black lines) in two bioswales, time (hr:min, $\mathrm{x}$ axis), and area of infiltration measurement (dashed box) in SE Portland, OR.

Root Sampling: Root samples were collected during two periods, January to February and May to June 2014. These two periods were selected as preliminary data (Chapter 1) within inner Southeast Portland suggested root mass density (RMD) was lowest during January to February (J-F) and highest during May to June (M-J). Soil cores were collected 1-3 days after a precipitation event so that all cores were collected at or near field capacity. This was done to increase the likelihood that the same volume of soil was being sampled for each soil core section as dry soil tends to shrink and wet soil expand. For each period, three $1 \mathrm{~m}$ deep cores per facility were collected (Selbig and Balster 2009) as negligible root densities had been recorded below this depth previously 
in Portland SBFs (Olney et al. 2010, unpublished data). Also, during winter it was difficult to get an accurate core sample below $1 \mathrm{~m}$ due to the saturation of the subsoil. For each facility, the coring location for each replicate was randomly selected within each of three equal sections (inlet, middle, and outlet) for a total of three replicates per facility. Auger locations were situated at least $0.3 \mathrm{~m}$ from bioswale walls to avoid facility edge effects. A soil recovery auger (AMS Inc., American Falls, ID) with a $25.4 \mathrm{~cm}$ x $8.4 \mathrm{~cm}$ core was used. This core kept the soil sample mostly intact while cutting some roots. This was appropriate as none of the root characteristics used in this study required completely intact roots, such as root length density (RLD, total length of roots per soil volume). After extraction, soil cores were left in the plastic liner and capped on both ends to avoid dehydration. Bentonite was poured into the empty auger holes and lightly compacted (Lesikar 2001). For each auger hole, depth of topsoil was measured and averaged for each facility.

Root Processing: Each core was weighed, wrapped in cellophane (Kokko et al. 1993), stored at $4^{\circ} \mathrm{C}$ temporarily in a dark fridge, and then processed within $24 \mathrm{hr}$ after extraction (Smit 2000, Lange et al. 2009). Root cores were cut into $8.4 \mathrm{~cm}$ increments with 720 total sections processed. Each increment was gently rinsed with DI water, poured through a $0.5 \mathrm{~mm}$ sieve to obtain $>90 \%$ of the roots (Livesley et al. 1999), and patted dry and separated into dark and light roots by eye for better image contrast (Smit 2000). Only roots $\geq 0.3 \mathrm{~mm}$ diameter were used for analysis as this was the minimum value for macropore flow (Jarvis 2007). Non-living roots from topsoil compost were quickly identified and discarded as they were brittle and much darker than live roots. 
Root Image Acquisition: A Canoscan 5600F scanner was used with grey scale at 600 dpi (dots per inch). No root staining was performed as background contrast with roots was adequate for analysis in WinRHIZO (Regent Instruments Inc., Quebec, Canada). Scanned area was confirmed by scanning rulers in the $\mathrm{x}$ and $\mathrm{y}$ directions on the scanner. Roots were then dried at $80^{\circ} \mathrm{C}$ for $48 \mathrm{hr}$ (Gregory 2006) using a drying oven (Model I-160B, ELE international, Bedfordshire, UK), each $8.4 \mathrm{~cm}$ depth section weighed (Livesley et al. 1999, Smit 2000), and root mass density (RMD, Table 2) was calculated. The soil volume sections were calculated using the height of each section (8.4 $\mathrm{cm})$, inner radius of the core $(3.6 \mathrm{~cm})$, and the equation for the volume of a cylinder $\left(\mathrm{V}=\pi \mathrm{r}^{2} \mathrm{~h}\right)$.

Root Image Analysis: Roots were analyzed using WinRHIZO for each $8.4 \mathrm{~cm}$ depth section to determine the following properties: root length density (RLD), specific root length (SRL), root surface area density (RSAD), root diameter (RD), and root volume density (RVD, Table 2). An 8-pixel search window was used (as opposed to a 128 pixel) when choosing a grey value threshold for assigning root vs. non-root to individual pixels in the images. This was done as the 8-pixel window tended not to clump root pieces with large numbers of branches and complexity as much as the 128-pixel window.

An alternative root image analysis software, RootSnap! (CID Bioscience, Camas, OR), was used to confirm any large or small root values. The same root images were used, each root manually measured by tracing from one end to the other end, and then the RootSnap! software computed total root length, area, and volume for that image. 
Table 2: Root characteristics measured including abbreviation, term, and description.

Abbreviation Term

\begin{tabular}{lll}
\hline RD & Root Diameter & Average root diameter \\
RMD & Root Mass Density & Total root mass per soil volume \\
RSAD & Root Surface Area Density & Total root surface area per unit soil volume \\
RVD & Root Volume Density & Total root volume per unit soil volume \\
RLD & Root Length Density & Total root length per unit soil volume \\
SRL & Specific Root Length & Total root length per total root dry mass
\end{tabular}

Statistical Analysis: To test precipitation data between time periods, root characteristics at different depths and between time periods (J-F and M-J), and infiltration rates between time periods the following tests were used. A Shapiro-Wilk normality test was used to determine if root and infiltration data were normally distributed. For normally distributed data, an unequal variance t-test was used (Bartens et al. 2008, Selbig and Balster 2009). For data not normally distributed, the nonparametric Wilcoxon rank sum test was used (Bartens et al. 2008, Selbig and Balster 2009).

Linear regression was used to determine the relationship between root characteristics (independent variable) and infiltration rate (dependent variable). Preliminary data (Chapter 1) suggested a large range for root characteristics and infiltration rate should be used to be able to capture a larger range of the root-infiltration relationship. Linear regression was also used to determine any relationship between variables controlled for (e.g. distance to groundwater) and infiltration rate metrics (e.g. average infiltration rate). Plots with residual versus fitted values were visually examined to determine if data followed a normal distribution (equal scatter around average residual 
value). Plots were omitted from analysis if this was not the case. R software (version 3.3.0) was used for all calculations.

Stepwise linear regression was used to compare the effect six root characteristics (RMD, RLD, SRL, RSAD, RD, and RVD within $1 \mathrm{~m}$, topsoil, and subsoil) had on infiltration rate during winter and late spring 2014. The Akaike information criterion (AIC) was used as the goodness of fit measure. To test model adequacy, the F test, Adjusted $\mathrm{R}^{2}$, confidence interval, and coefficient of variation were used. To test model assumptions (linear relationship, multivariate normality, no or little multicollinearity, no auto-correlation, homoscedasticity or equal variance) diagnostic plots were visually examined, variance inflation factor was used, and correlations were calculated. To validate a model, range in predicted values were compared to the range in response variable (infiltration rate). Transformations were considered to satisfy model assumptions.

\section{Results}

Precipitation Seasonal Change: During the two periods (J-F and M-J 2014) examined for root-enhanced infiltration, precipitation of $23.3 \mathrm{~cm}$ during $\mathrm{J}-\mathrm{F}$ and $11.6 \mathrm{~cm}$

during M-J was similar to the $21.8 \mathrm{~cm}$ average during $\mathrm{J}-\mathrm{F}$ and $11.8 \mathrm{~cm}$ average during MJ for the previous ten years (2004 to 2013, Fig. 5). All the monthly precipitation values measured during 2014-15 were well within two standard deviations of the monthly averages for the previous ten years (Fig. 5). More than twice the amount of precipitation fell during J-F 2014 (23.3 cm, Fig. 6) and March-April (32.1 cm, Fig. 7) compared to M-J 
$2014(11.6 \mathrm{~cm})$. Also, the average precipitation depth per rain event (Fig. 8) and average time of a precipitation event (Fig. 9) was greater during J-F compared to M-J 2014. Infiltration Seasonal Change: Infiltration rate showed a seasonal change from January 2014 to February 2015 (Fig. 5). The average infiltration rate for all 10 facilities was lowest during the winter months (Oct-Feb) averaged around $3.7 \mathrm{~cm} / \mathrm{hr}$, increased Feb to Mar, averaged around $5.7 \mathrm{~cm} / \mathrm{hr}$ from Mar-May, peaked at $8 \mathrm{~cm} / \mathrm{hr}$ in Aug, decreased Sept to Oct, and averaged around $3.7 \mathrm{~cm} / \mathrm{hr}$ in the winter (Dec 2014 - Feb 2015). Weekly infiltration variability (standard error) was lower during J-F (0.06 cm/hr, Fig. 6) compared to M-J $2014(0.22 \mathrm{~cm} / \mathrm{hr})$. The average infiltration rate increased 42\% from J-F 2014 to M-J 2014 and 109\% from J-F to July-August 2014 (Fig. 10). 

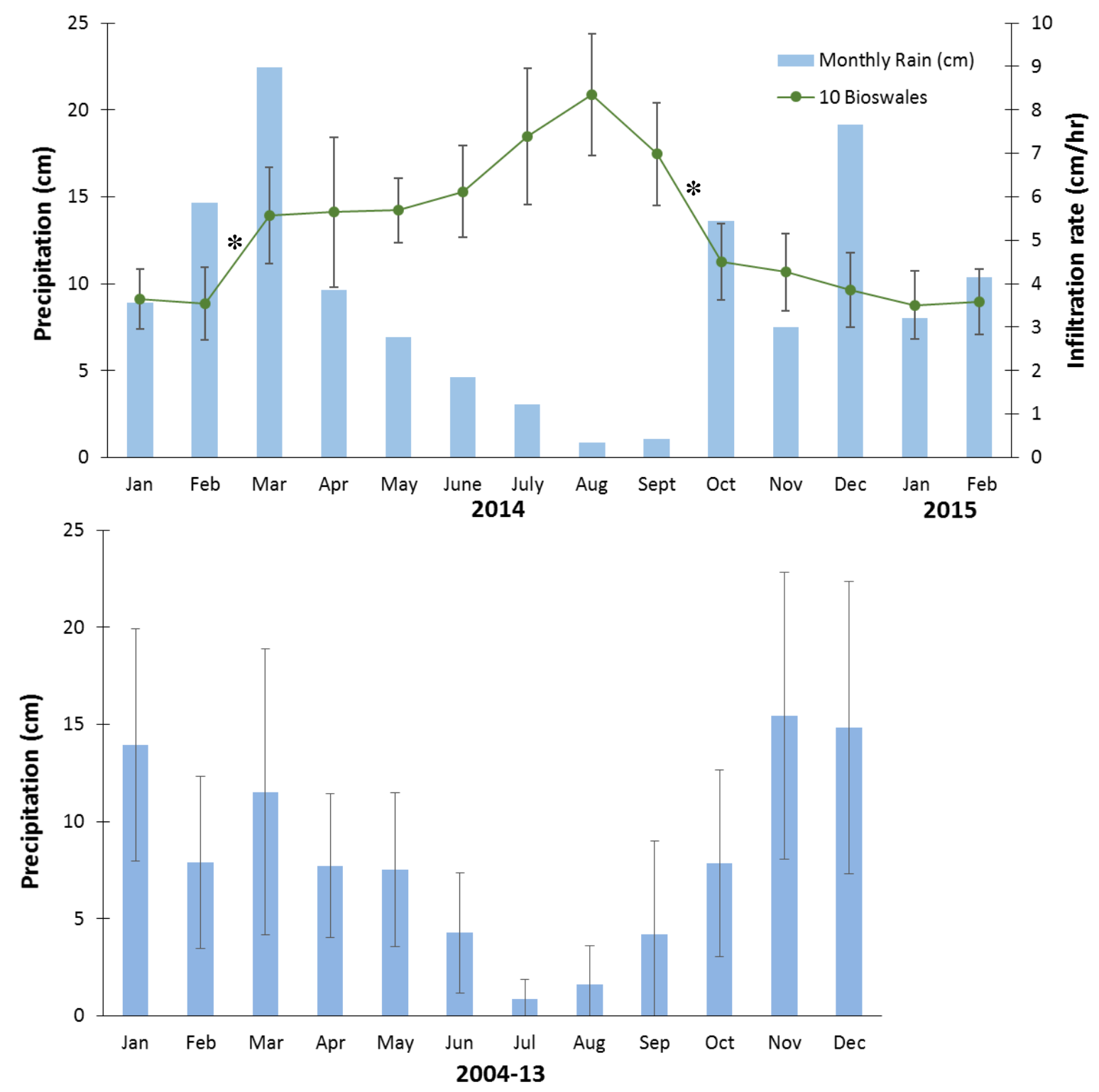

Figure 5: Top graph: Monthly precipitation (bars), average monthly infiltration rate (line, $\mathrm{n}=10$ bioswales), and standard error of monthly infiltration rate (error bars) during 2014 (top). *Indicates significant increase or decrease in infiltration from one month to the next (Wilcoxon rank sum tests, p-value < 0.05) during 2014 and 2015. Bottom graph: Average monthly precipitation (bars, $n=10$ years) and standard deviation (error bars) during 2004 to 2013. Precipitation data used were from HYDRA City of Portland Water gage network (USGS 2015). 

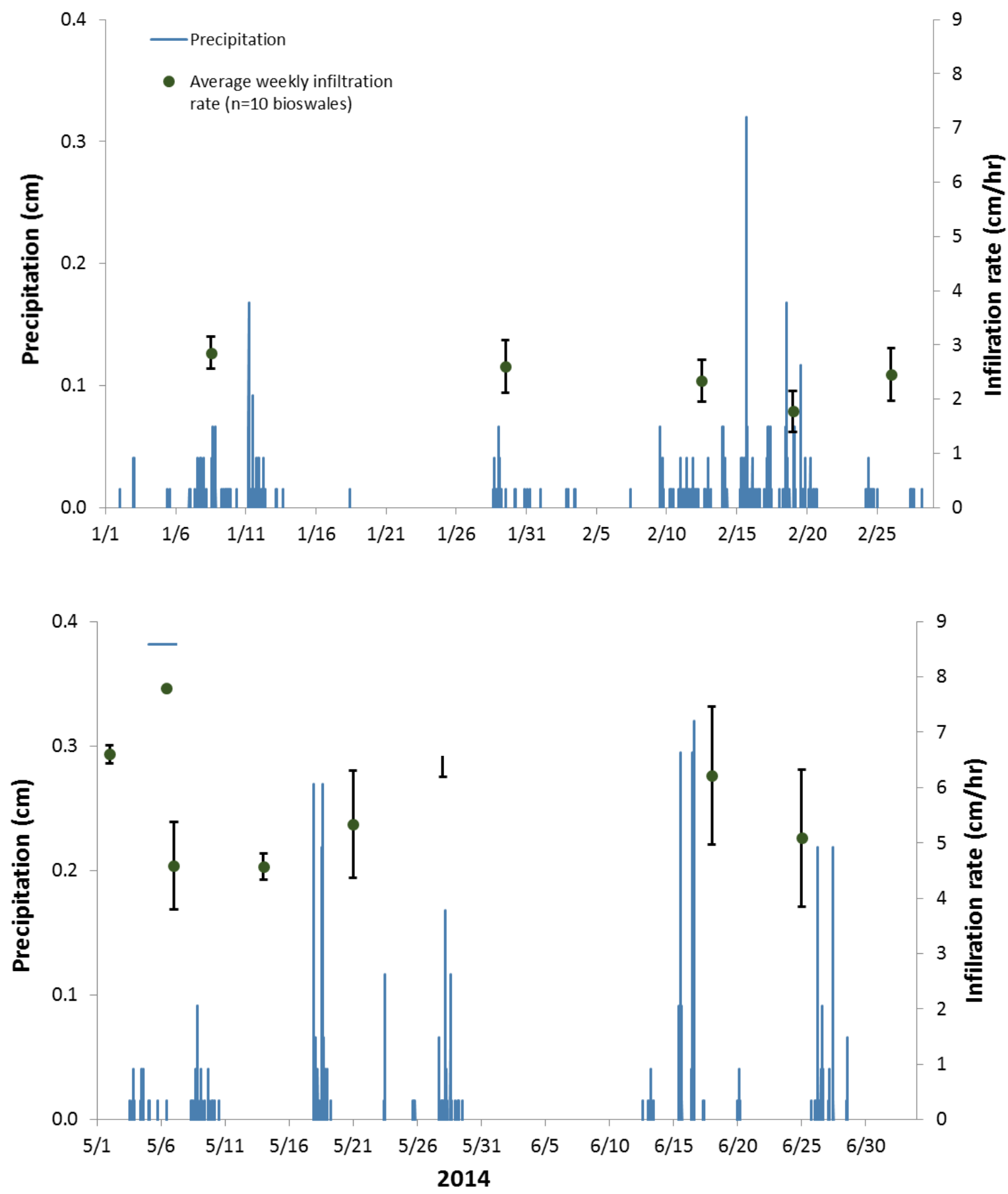

Figure 6: J-F (top) and M-J (bottom) 2014 precipitation every 5 minutes (bars) and average weekly infiltration rates (circles) and standard error of weekly infiltration rates (error bars). 


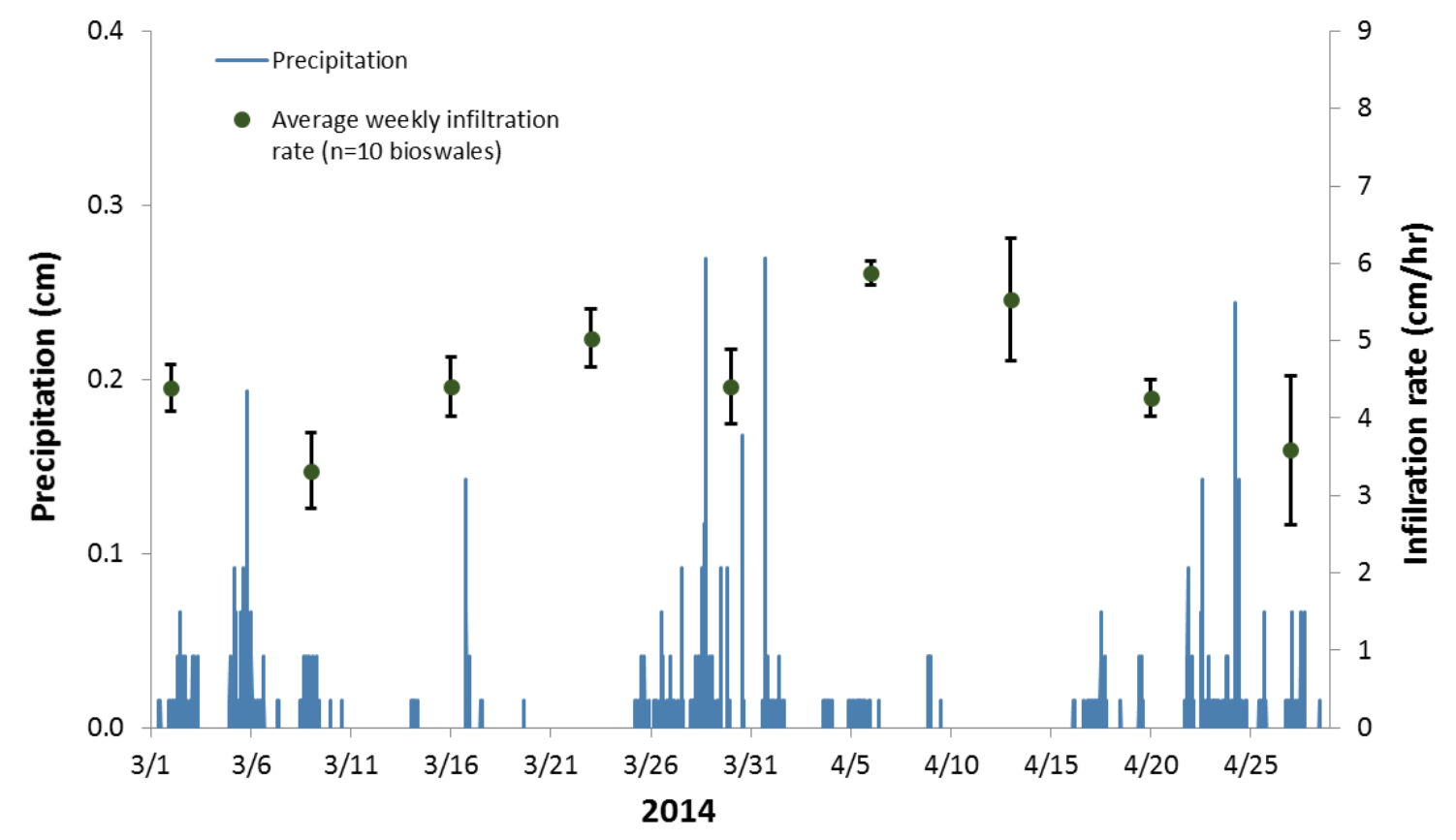

Figure 7: March to April 2014 precipitation every 5 minutes (bars) and average weekly infiltration rates (circles) and standard error of weekly infiltration rates (error 


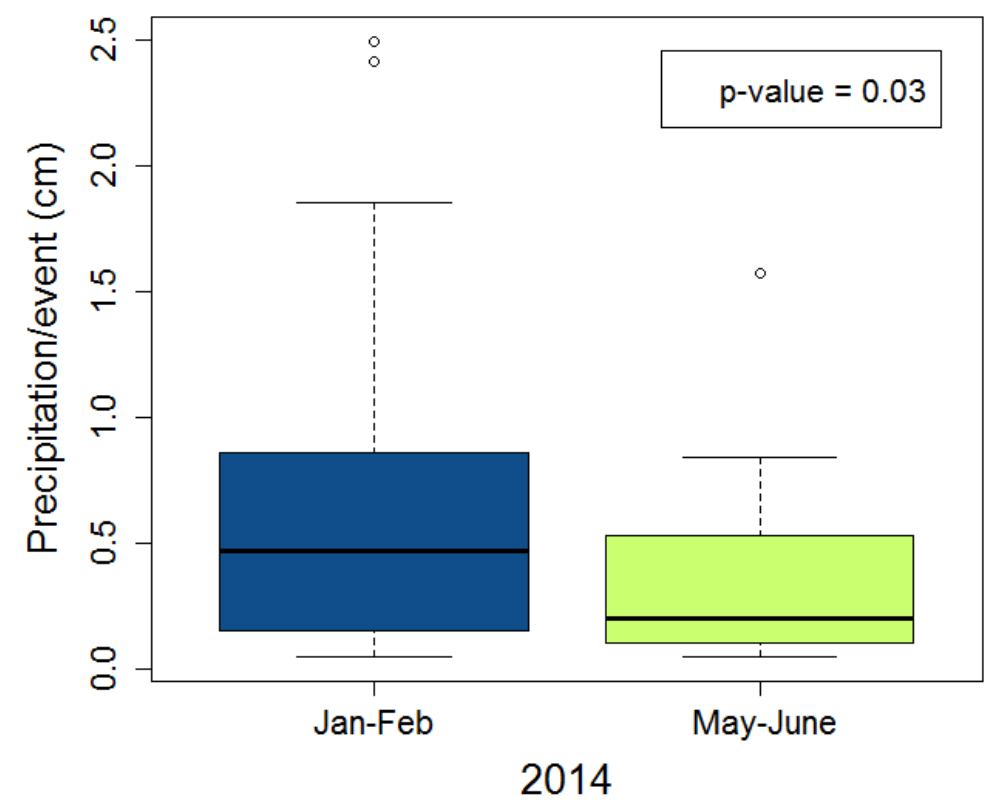

Figure 8: Precipitation/event during J-F ( $\mathrm{n}=33)$ and M-J $(\mathrm{n}=25)$ in 10 Juncus bioswales. P-value determined using Wilcoxon rank sum test.

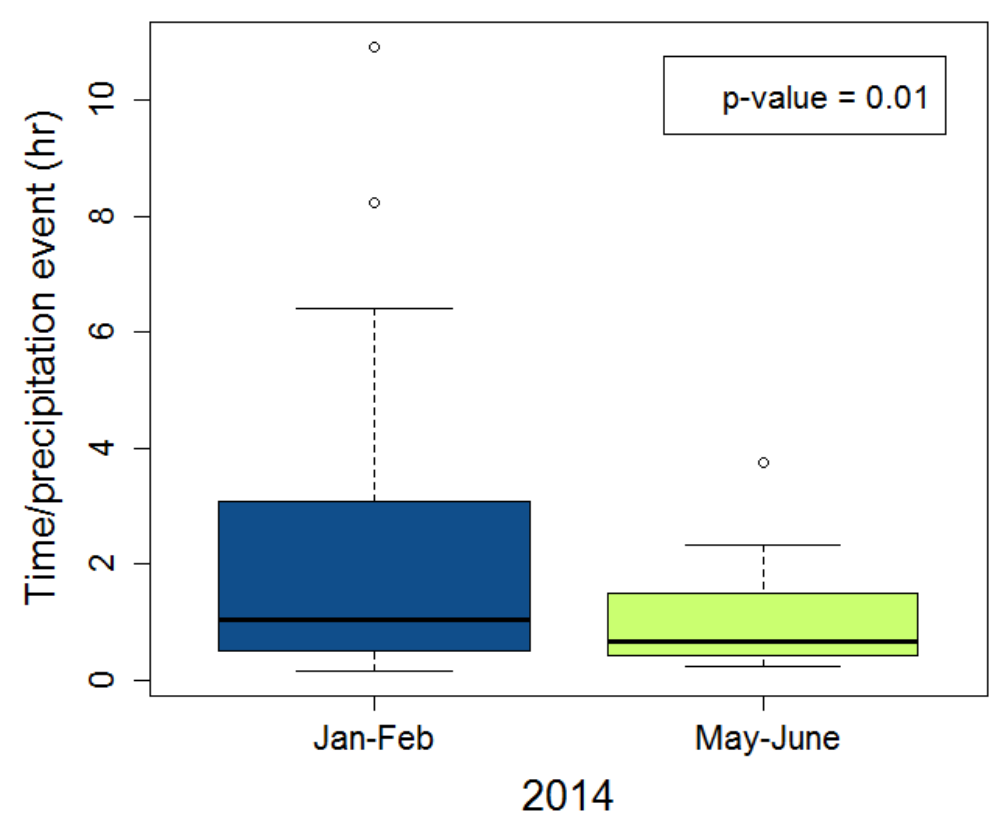

Figure 9: Time per precipitation event during $\mathrm{J}-\mathrm{F}(\mathrm{n}=33)$ and $\mathrm{M}-\mathrm{J}(\mathrm{n}=25)$ in 10 Juncus bioswales. P-value determined using Wilcoxon rank sum test. 


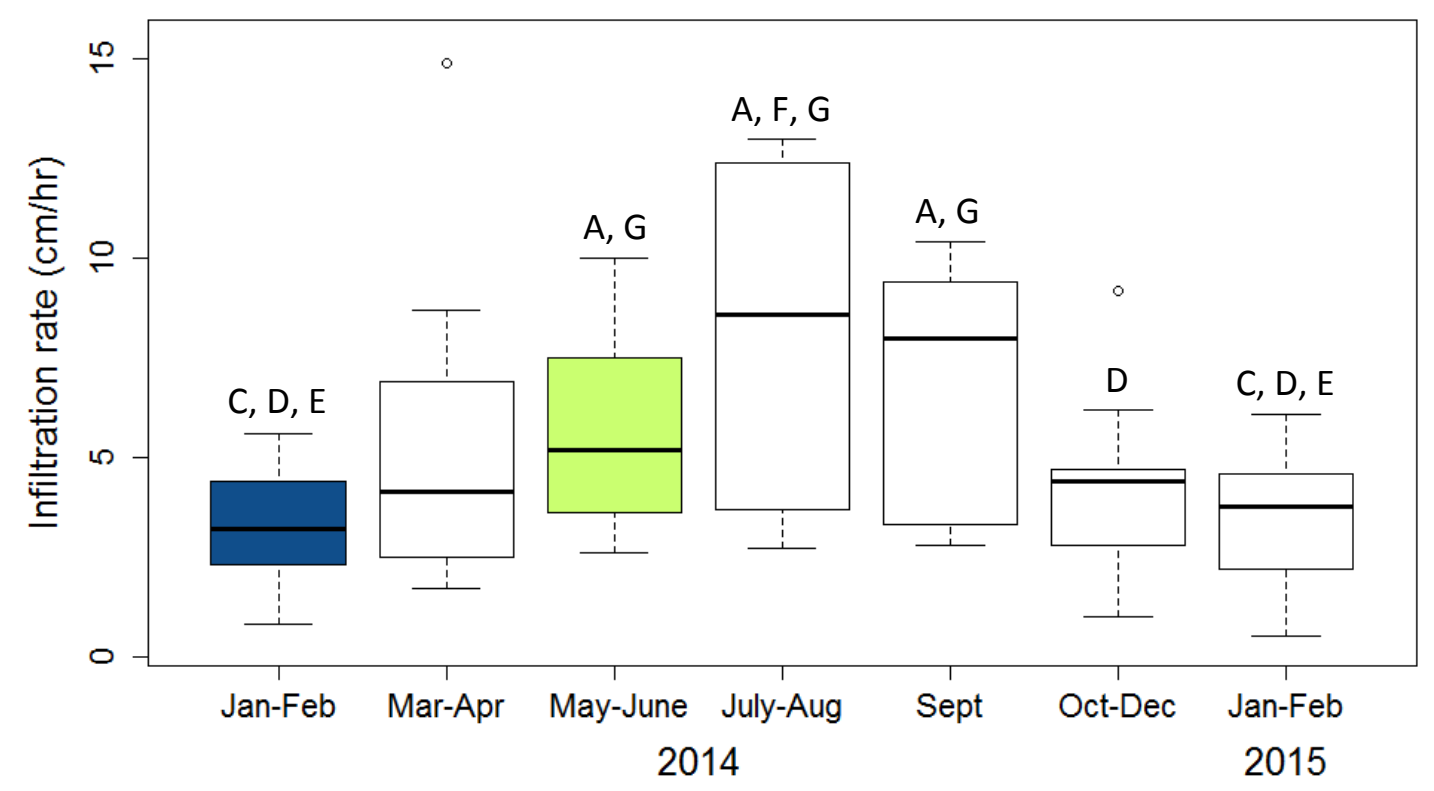

Figure 10: Infiltration rate during J-F (A), Mar-Apr (B), M-J (C), July-Aug (D), Sept (E), Oct-Dec 2014 (F), and J-F 2015 (G) in 10 Juncus bioswales. Text above bars (e.g. A, G) indicate significant difference with other months (Wilcoxon rank sum test).

Root Mass Density (RMD): RMD increase (J-F to M-J 2014) was shown within the $1 \mathrm{~m}$ soil profile $(\mathrm{p}$-value $=0.04)$ and subsoil $(\mathrm{p}$-value $=0.02$, Fig. 11 , Table 3$)$. RMD was greater within the topsoil compared to the subsoil during J-F and M-J 2014 (Table 3). Specifically, RMD increased at 4 depth increments within the subsoil but not within any depth increments in the topsoil. RMD showed a positive relationship within the $1 \mathrm{~m}$ root profile $\left(\mathrm{R}^{2}=0.51\right.$, Fig. 12$)$, the subsoil $\left(50-100 \mathrm{~cm}\right.$ depth, $R^{2}=0.43$, Fig. 13$)$, and the topsoil (0-50 cm depth, $\mathrm{R}^{2}=0.36$, Fig. 13). In addition, RMD increase within $1 \mathrm{~m}$ soil profile $\left(\mathrm{R}^{2}=0.47\right)$ and subsoil $\left(\mathrm{R}^{2}=0.49\right)$ showed a positive relationship to the increase in infiltration rate (Fig. 14). 


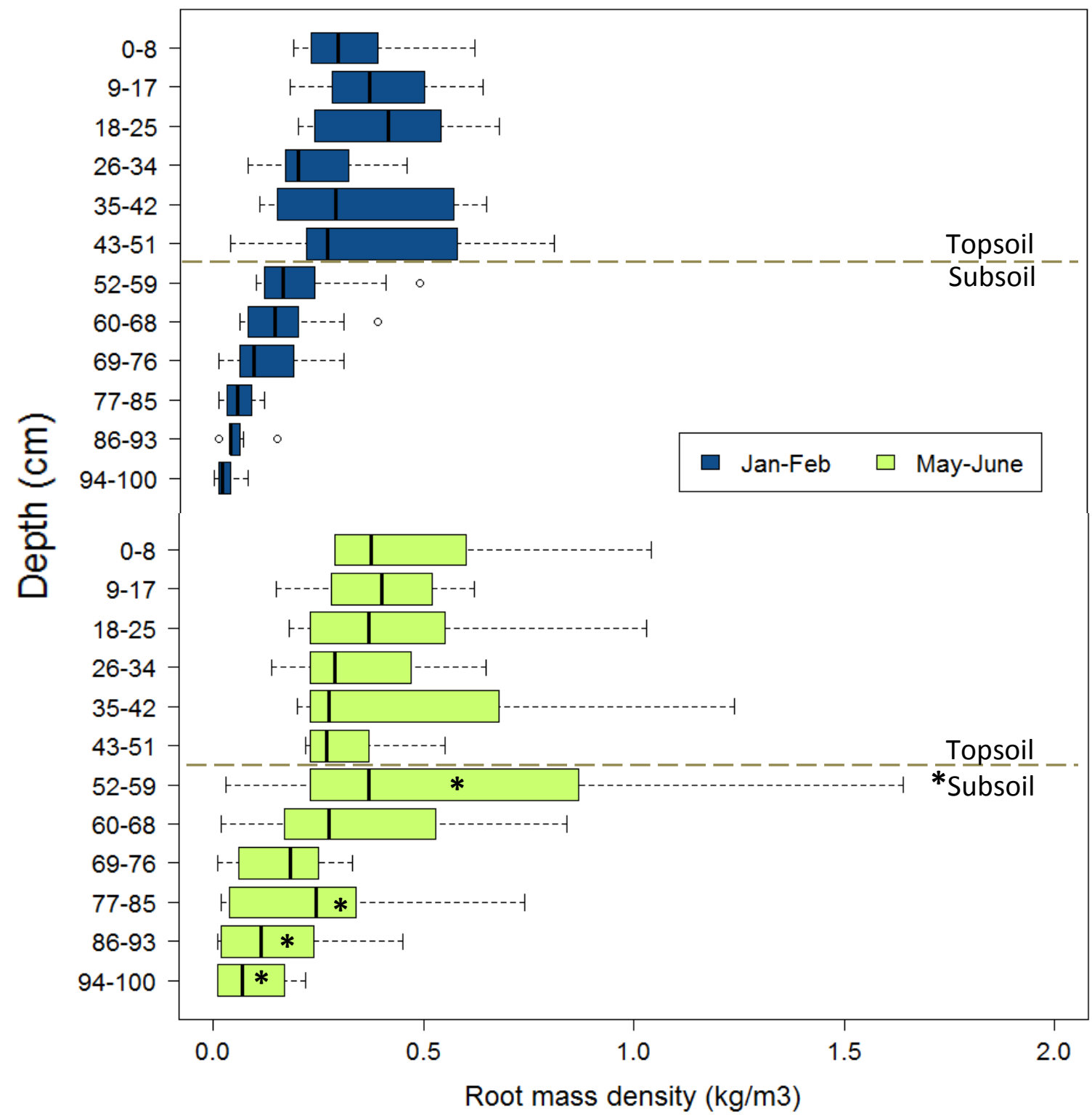

Figure 11: Root mass density (RMD) J-F (top) and M-J (bottom) by $8.5 \mathrm{~cm}$ depth increments. *Significant increase in RMD from J-F (top) to M-J (bottom) using a t-test (unequal variance, normal distribution). Each depth increments represents $n=10$ (SBFs). 
Table 3: Root characteristic values and percent increase (gray boxes) from JanuaryFebruary to May-June 2014 at different depths. These include root mass density (RMD), root length density (RLD), root surface area density (RSAD), root diameter (RD), and root volume density (RVD). Dashed line indicates average division between topsoil and subsoil. Significant increase in root characteristics determined by using Wilcoxon rank sum test ( $\mathrm{p}$-value $<0.05)$.

\begin{tabular}{|c|c|c|c|c|c|c|c|c|c|c|c|c|}
\hline \multirow[b]{2}{*}{$\begin{array}{l}\text { Depth } \\
(\mathrm{cm})\end{array}$} & \multicolumn{6}{|c|}{ January-February } & \multicolumn{6}{|c|}{ May-June } \\
\hline & $\begin{array}{l}\text { RMD } \\
\left(\mathrm{kg} / \mathrm{m}^{3}\right)\end{array}$ & $\begin{array}{l}\mathrm{RD} \\
(\mathrm{mm})\end{array}$ & $\begin{array}{l}\text { RSAD } \\
\left(\mathrm{cm}^{2} / \mathrm{cm}^{3}\right)\end{array}$ & $\begin{array}{l}\text { RVD } \\
\left(\mathrm{cm}^{3} / \mathrm{cm}^{3}\right)\end{array}$ & $\begin{array}{l}\text { RLD } \\
\left(\mathrm{cm} / \mathrm{cm}^{3}\right)\end{array}$ & $\begin{array}{l}\mathrm{SRL} \\
(\mathrm{m} / \mathrm{g})\end{array}$ & $\begin{array}{l}\text { RMD } \\
\left(\mathrm{kg} / \mathrm{m}^{3}\right)\end{array}$ & $\begin{array}{l}\text { RD } \\
(\mathrm{mm})\end{array}$ & $\begin{array}{l}\text { RSAD } \\
\left(\mathrm{cm}^{2} / \mathrm{cm}^{3}\right)\end{array}$ & $\begin{array}{l}\text { RVD } \\
\left(\mathrm{cm}^{3} / \mathrm{cm}^{3}\right)\end{array}$ & $\begin{array}{l}\text { RLD } \\
\left(\mathrm{cm} / \mathrm{cm}^{3}\right)\end{array}$ & $\begin{array}{l}\text { SRL } \\
(\mathrm{m} / \mathrm{g})\end{array}$ \\
\hline $0-8$ & 0.32 & 0.92 & 0.49 & $\quad 0.010$ & 1.46 & 18.2 & 0.48 & $\begin{array}{r}1.05 \\
(14 \%)\end{array}$ & $\begin{array}{r}0.72 \\
(47 \%)\end{array}$ & $\begin{array}{r}0.017 \\
(63 \%)\end{array}$ & 1.91 & 17.5 \\
\hline $9-17$ & 0.39 & 0.90 & 0.53 & 0.013 & 1.48 & 16.1 & 0.39 & $\begin{array}{r}1.17 \\
(31 \%)\end{array}$ & 0.58 & 0.015 & 1.43 & 16.0 \\
\hline $18-25$ & 0.39 & 1.09 & 0.46 & 0.013 & 1.16 & 12.0 & 0.46 & $\begin{array}{r}1.23 \\
(13 \%)\end{array}$ & 0.53 & 0.013 & 1.19 & 11.8 \\
\hline $26-34$ & 0.24 & 0.93 & 0.30 & 0.007 & 0.89 & 15.5 & 0.34 & $\begin{array}{r}1.18 \\
(27 \%)\end{array}$ & $\begin{array}{r}0.43 \\
(44 \%)\end{array}$ & $\begin{array}{r}0.011 \\
(59 \%)\end{array}$ & 1.07 & 12.5 \\
\hline $35-42$ & 0.36 & 1.00 & 0.45 & 0.011 & 1.26 & 18.9 & 0.56 & $\begin{array}{r}1.25 \\
(25 \%)\end{array}$ & 0.51 & 0.014 & 1.24 & 11.4 \\
\hline $43-51$ & 0.36 & 0.99 & 0.41 & 0.009 & 1.17 & 19.7 & 0.33 & $\begin{array}{r}1.19 \\
(21 \%)\end{array}$ & 0.44 & 0.012 & 1.03 & 13.2 \\
\hline $52-59$ & 0.22 & 1.01 & 0.37 & 0.008 & 1.12 & 19.6 & $0 . \overline{58}$ & 1.13 & 0.47 & 0.013 & 1.26 & $\overline{13.1}$ \\
\hline $60-68$ & 0.17 & 0.95 & 0.23 & 0.005 & 0.64 & 18.7 & $\begin{array}{r}0.36 \\
(112 \%)\end{array}$ & 1.00 & $\begin{array}{r}0.40 \\
(73 \%)\end{array}$ & $\begin{array}{r}0.009 \\
(78 \%)\end{array}$ & $\begin{array}{r}1.08 \\
(68 \%)\end{array}$ & 18.7 \\
\hline 69-76 & 0.12 & 0.94 & 0.09 & 0.004 & 0.25 & 9.3 & 0.17 & 1.02 & $\begin{array}{r}0.36 \\
(282 \%)\end{array}$ & $\begin{array}{r}0.008 \\
(136 \%)\end{array}$ & $\begin{array}{r}0.97 \\
(283 \%)\end{array}$ & 28.7 \\
\hline $77-85$ & 0.06 & 0.88 & 0.07 & 0.002 & 0.25 & 16.9 & $\begin{array}{r}0.24 \\
(320 \%)\end{array}$ & 0.97 & $\begin{array}{r}0.29 \\
(293 \%)\end{array}$ & $\begin{array}{r}0.007 \\
(184 \%)\end{array}$ & $\begin{array}{r}0.81 \\
(221 \%)\end{array}$ & 25.7 \\
\hline $86-93$ & 0.05 & 0.80 & 0.11 & 0.003 & 0.29 & 15.6 & $\begin{array}{r}0.14 \\
(195 \%)\end{array}$ & 0.94 & 0.24 & 0.006 & $\begin{array}{r}0.65 \\
(125 \%)\end{array}$ & 43.9 \\
\hline $94-100$ & 0.03 & 0.59 & 0.07 & 0.002 & 0.21 & 16.0 & $\begin{array}{r}0.09 \\
(240 \%) \\
\end{array}$ & $\begin{array}{r}1.08 \\
(83 \%) \\
\end{array}$ & 0.19 & 0.004 & 0.48 & 22.9 \\
\hline $\begin{array}{l}\text { Topsoil: } \\
(0-50 \mathrm{~cm})\end{array}$ & $0.33^{\top}$ & 0.97 & $0.43^{\top}$ & $0.010^{\top}$ & $1.21^{\top}$ & 15.9 & $0.45^{\top}$ & $\begin{array}{r}1.18^{\top} \\
(21 \%) \\
\end{array}$ & $\begin{array}{c}0.54^{\top} \\
(26 \%)\end{array}$ & $\begin{array}{l}0.014^{\top} \\
(33 \%) \\
\end{array}$ & $1.33^{\top}$ & 13.7 \\
\hline 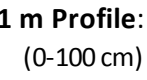 & 0.22 & 0.95 & 0.34 & 0.008 & 0.95 & 17.3 & $\begin{array}{r}0.34 \\
(54 \%) \\
\end{array}$ & $\begin{array}{r}1.10 \\
(16 \%) \\
\end{array}$ & $\begin{array}{r}0.43 \\
(27 \%) \\
\end{array}$ & $\begin{array}{r}0.011 \\
(36 \%)\end{array}$ & 1.10 & 19.4 \\
\hline $\begin{array}{r}\text { Subsoil: } \\
(50-100 \mathrm{~cm})\end{array}$ & 0.12 & 0.89 & 0.24 & 0.005 & 0.63 & 19.2 & $\begin{array}{r}0.24 \\
(109 \%) \\
\end{array}$ & $\begin{array}{r}1.02 \\
(15 \%) \\
\end{array}$ & $\begin{array}{r}0.34 \\
(45 \%) \\
\end{array}$ & 0.007 & 0.86 & 25.3 \\
\hline & & $\begin{array}{l}=\text { Signi } \\
\text { Februa } \\
\text { increas }\end{array}$ & $\begin{array}{l}\text { ificant incre } \\
\text { ary to May-J } \\
\text { se in parant }\end{array}$ & $\begin{array}{l}\text { ease from Ja } \\
\text { June } 2014, p \\
\text { theses }\end{array}$ & $\begin{array}{l}\text { anuary- } \\
\text { percent }\end{array}$ & & $\begin{array}{l}=\text { Significa } \\
\text { characteris } \\
\text { compared }\end{array}$ & $\begin{array}{l}\text { antly gr } \\
\text { istic val } \\
\text { to the }\end{array}$ & $\begin{array}{l}\text { reater root } \\
\text { lue within th } \\
\text { susboil }\end{array}$ & he topsoil & & \\
\hline
\end{tabular}




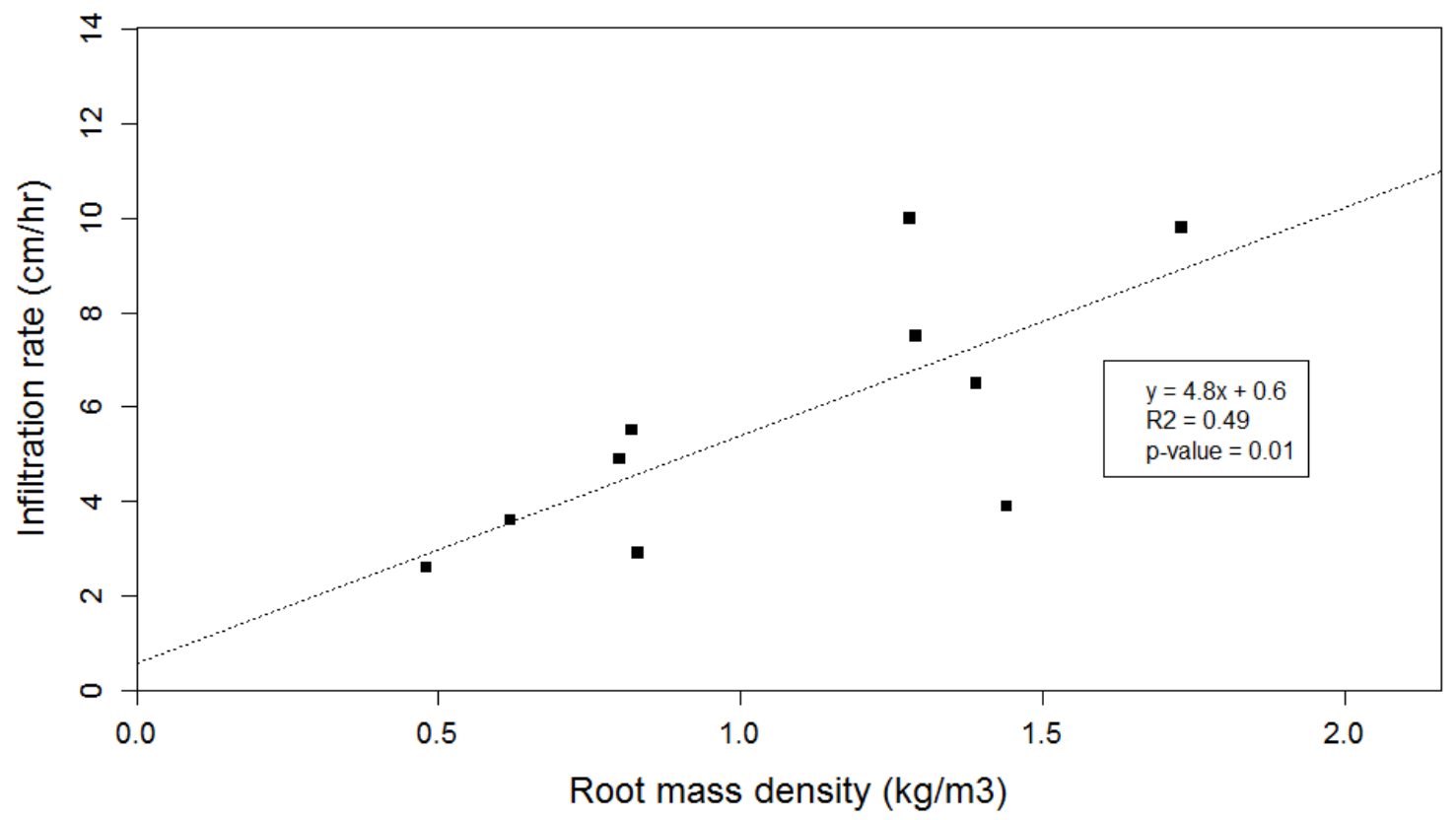

Figure 12: Root mass density within $1 \mathrm{~m}$ soil profile and infiltration rate during M-J 2014 within 10 bioswales in Portland, OR.

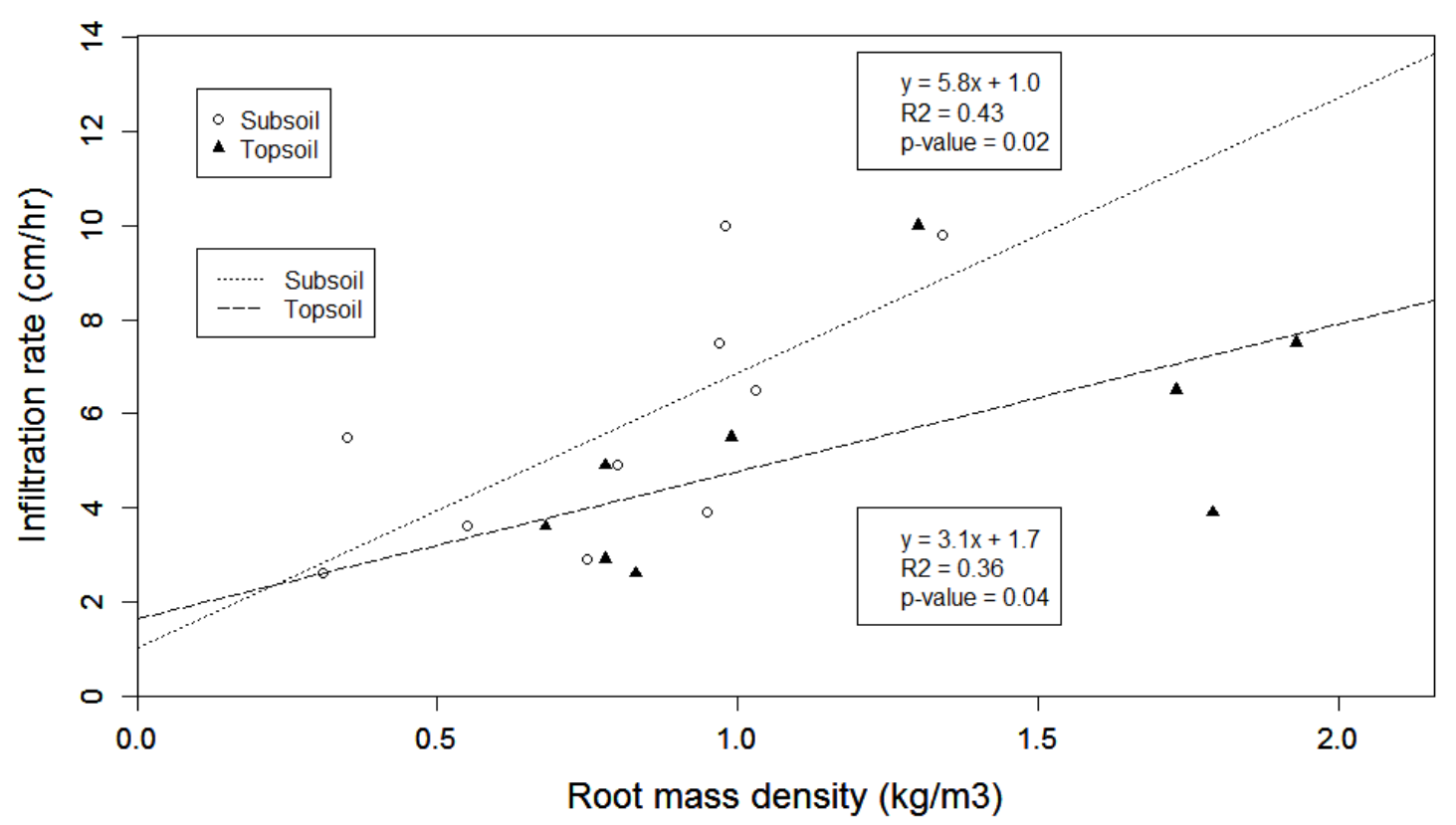

Figure 13: Root mass density within subsoil and topsoil and infiltration rate M-J 2014 within 10 bioswales in Portland, OR. 


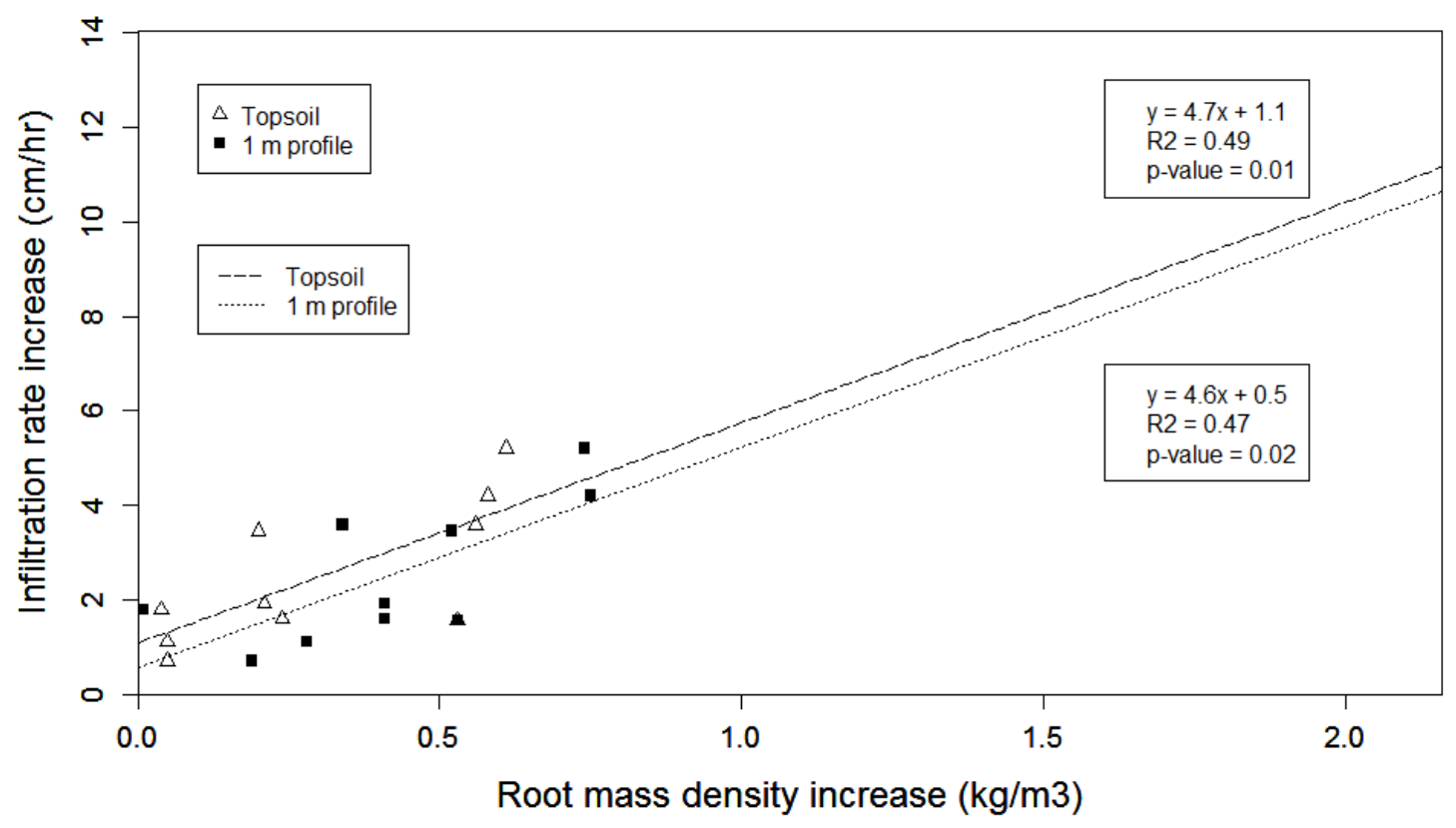

Figure 14: Root mass density (RMD) increase from J-F to M-J 2014 and infiltration rate increase from J-F to M-J 2014 in 10 Juncus SBFs.

Root Diameter $(R D)$ : RD increase was shown in the $1 \mathrm{~m}$ profile, subsoil, topsoil, and for all depth increments except from 52 to $93 \mathrm{~cm}$ (Fig. 15, Table 3). RD was greater within the topsoil compared to the subsoil during M-J 2014 (Table 3). Within the topsoil, $\mathrm{RD}$ and infiltration rate showed a positive relationship $\left(\mathrm{R}^{2}=0.57\right.$, Fig. 16$)$. Also, the ratio of topsoil to subsoil $\mathrm{RD}$ showed a positive relationship $\left(\mathrm{R}^{2}=0.55\right.$, Fig. 17). $\mathrm{RD}$ increase within the topsoil showed a positive relationship with the infiltration rate increase $\left(\mathrm{R}^{2}=0.58\right.$, Fig. 18). 


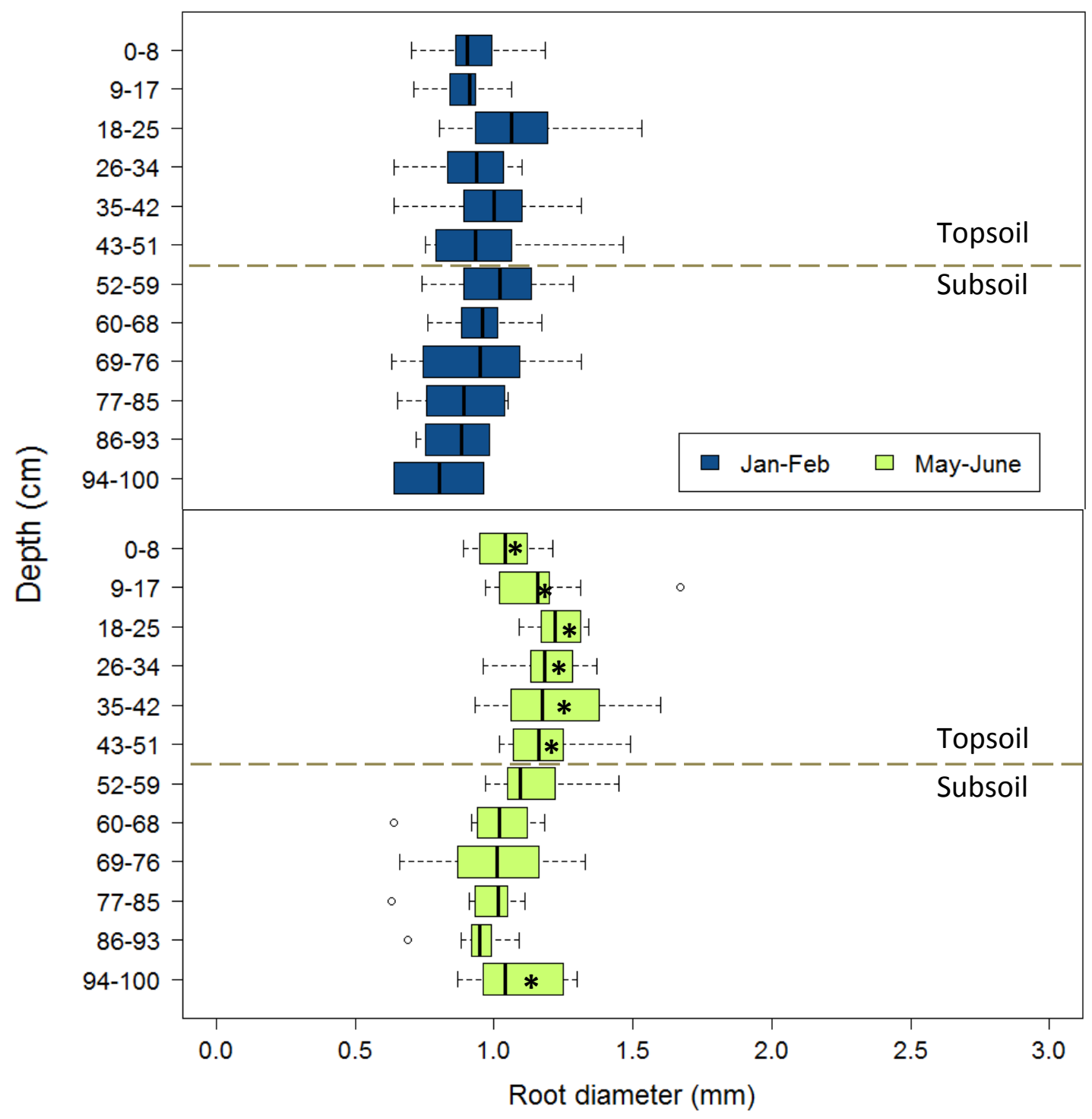

Figure 15: Root diameter J-F (top) and M-J (bottom) by $8.5 \mathrm{~cm}$ depth increments. *Significant increase in root diameter from J-F (top) to M-J (bottom) using a t-test (unequal variance, normal distribution). Each depth increments represents $n=10$ (SBFs). 


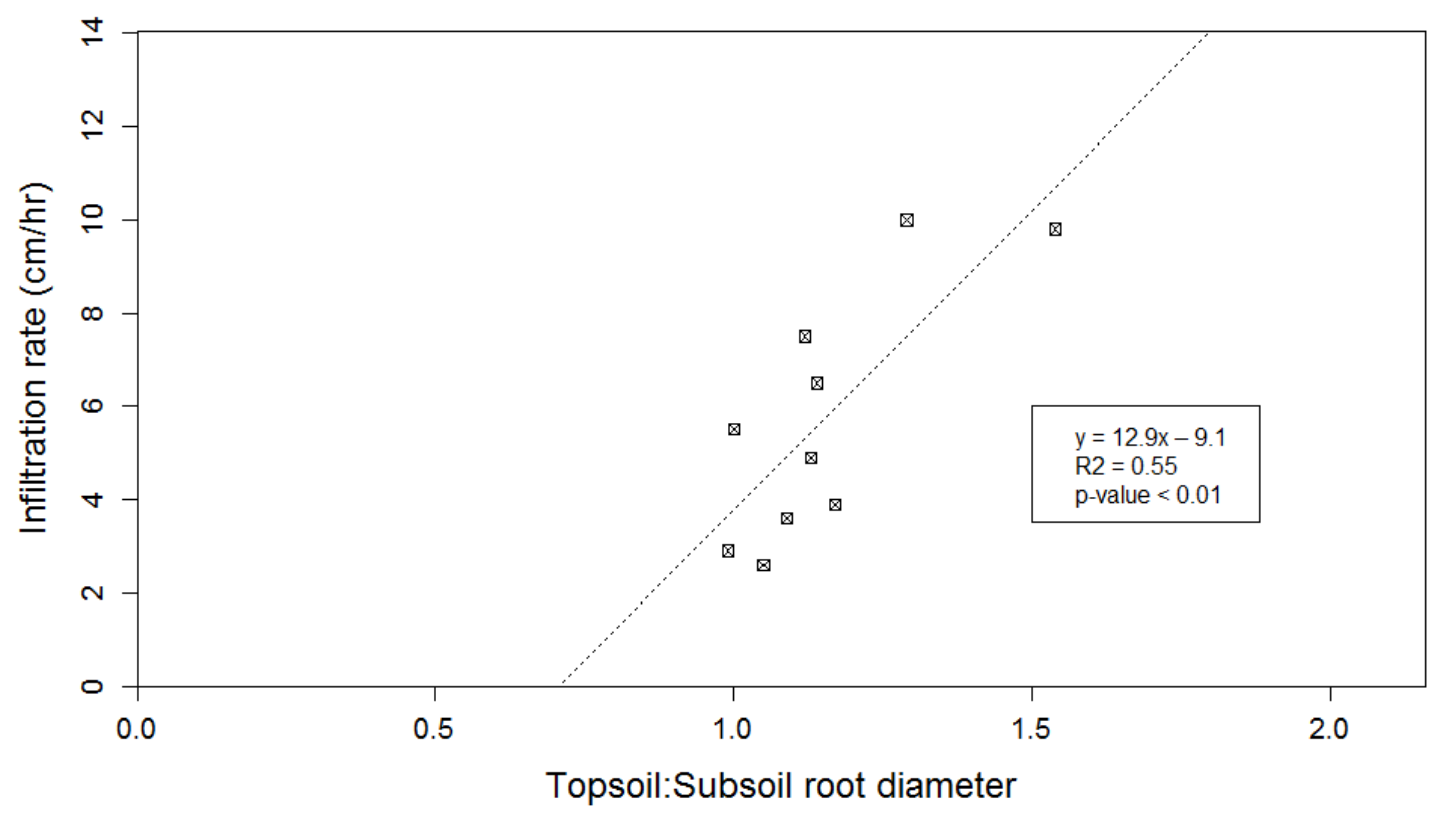

Figure 16: Ratio of topsoil to subsoil root diameter and infiltration rate during M-J 2014 within 10 bioswales in Portland, OR.

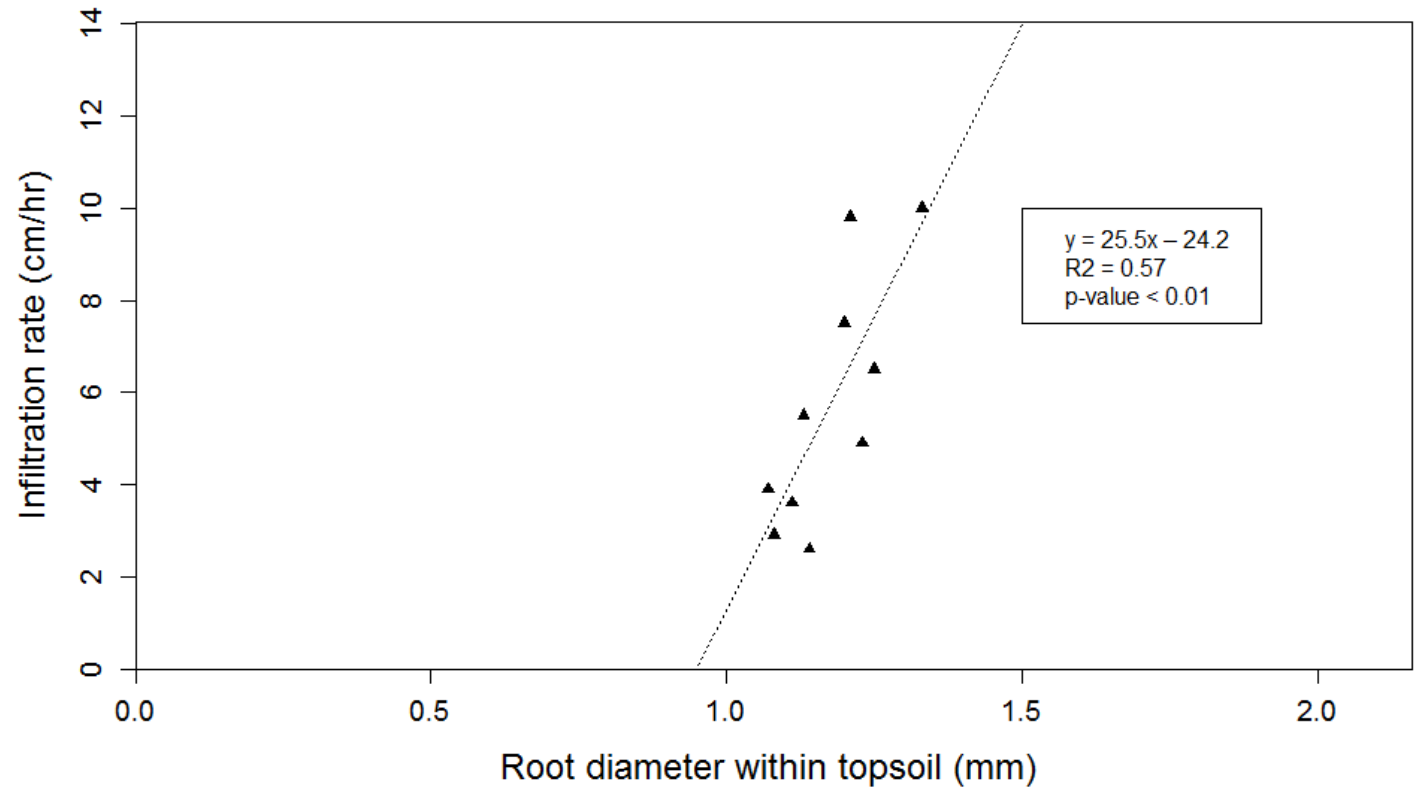

Figure 17: Root diameter within topsoil and infiltration rate during M-J 2014 within 10 bioswales in Portland, OR. 


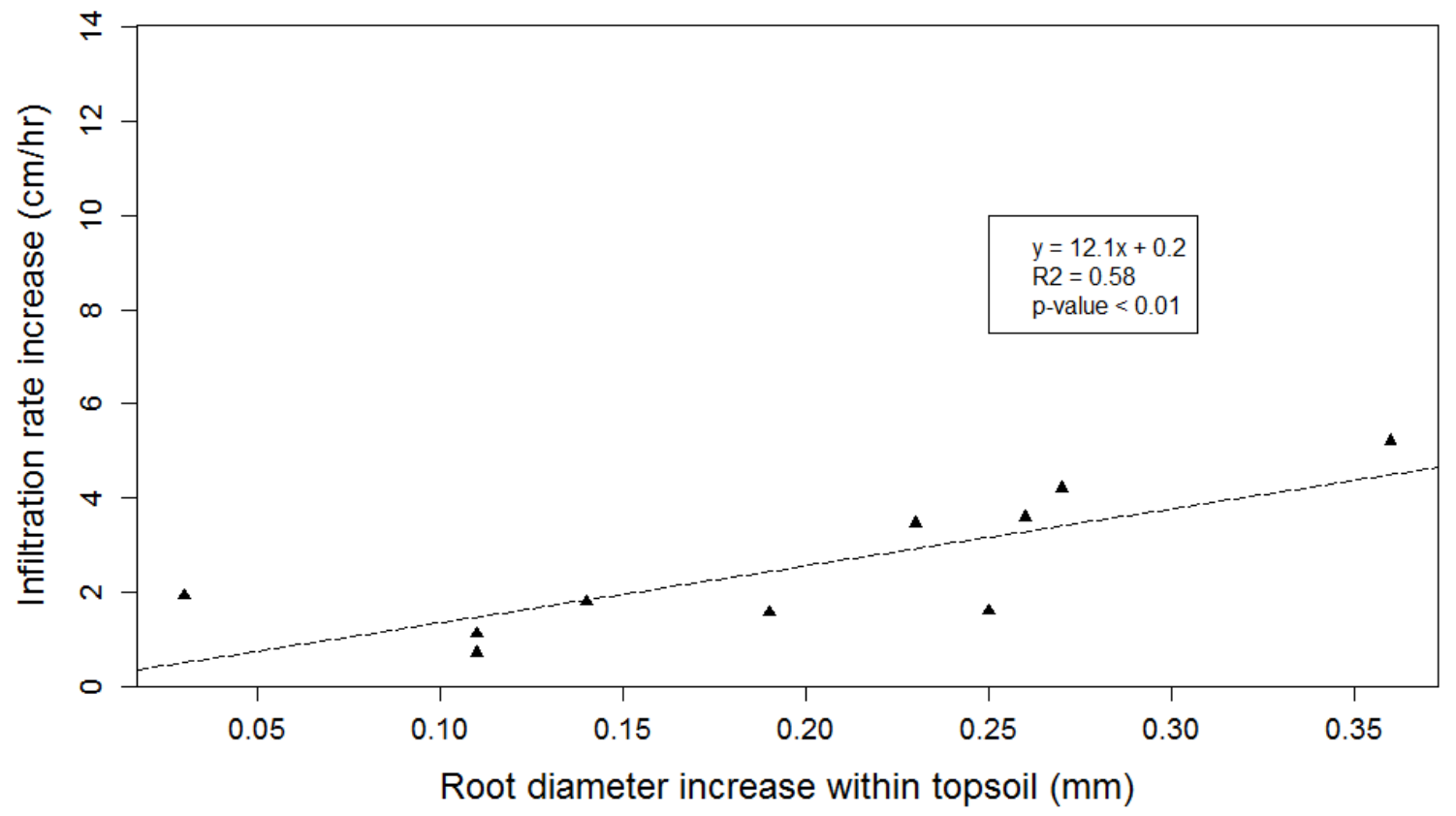

Figure 18: Root diameter increase within the topsoil and infiltration rate increase (from J-F to M-J 2014) within 10 bioswales in Portland, OR.

Root Surface Area Density (RSAD): RSAD increase was shown in the topsoil, $1 \mathrm{~m}$ profile, subsoil, and more specifically for the 0-8, 26-34, 60-85 cm depths (Fig. 19, Table 3). RSAD was greater within the topsoil compared to the subsoil during J-F and M-J 2014 (Table 3). RSAD increase within the topsoil showed a positive relationship with the increase in infiltration rate $\left(\mathrm{R}^{2}=0.54\right.$, Fig. 20$)$. 


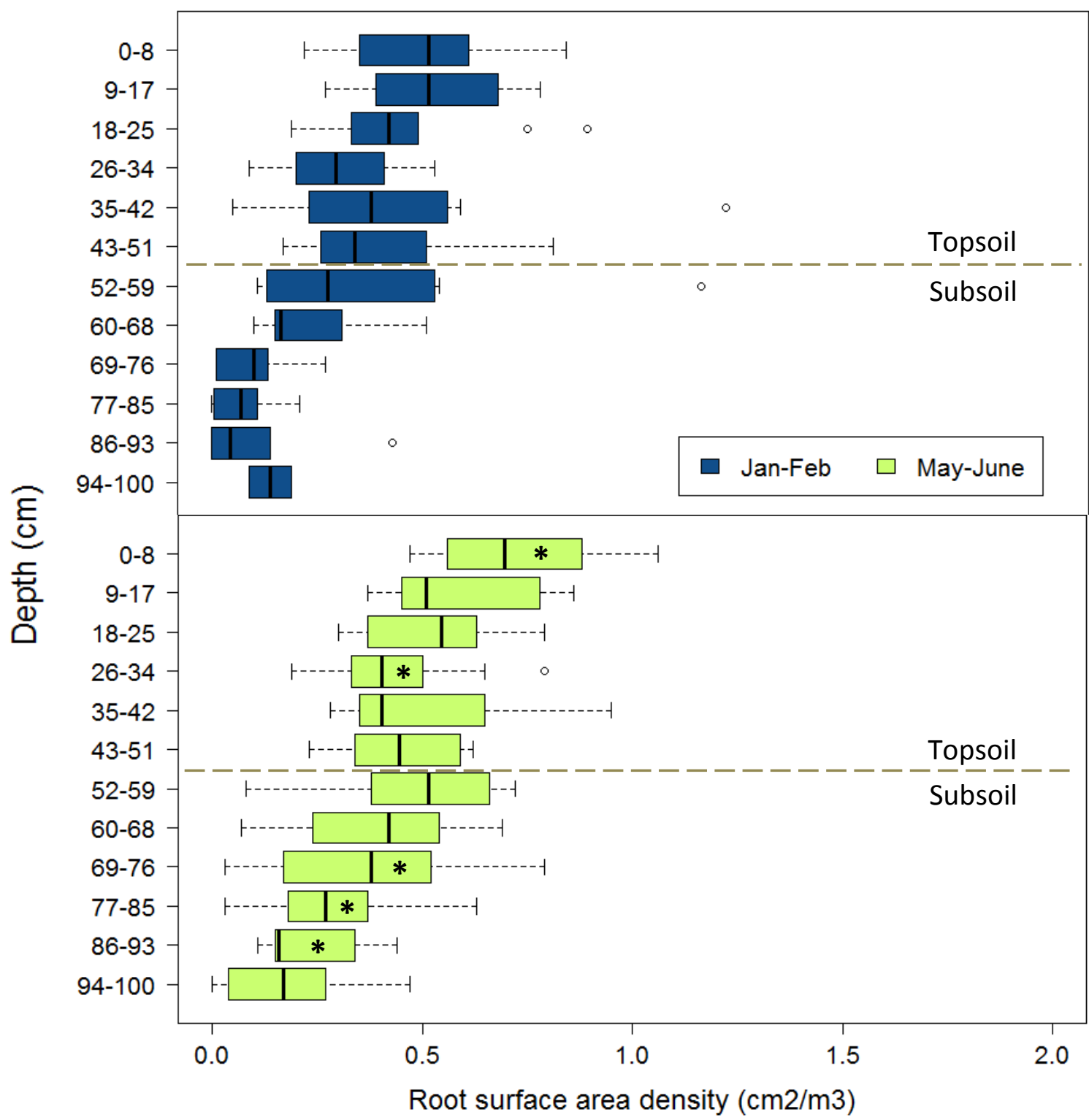

Figure 19: Root surface area density (RSAD) J-F (top) and M-J (bottom) by $8.5 \mathrm{~cm}$ depth increments. *Significant increase in RSAD from J-F (top) to M-J (bottom) using a t-test (unequal variance, normal distribution) and Wilcoxon rank sum test. 


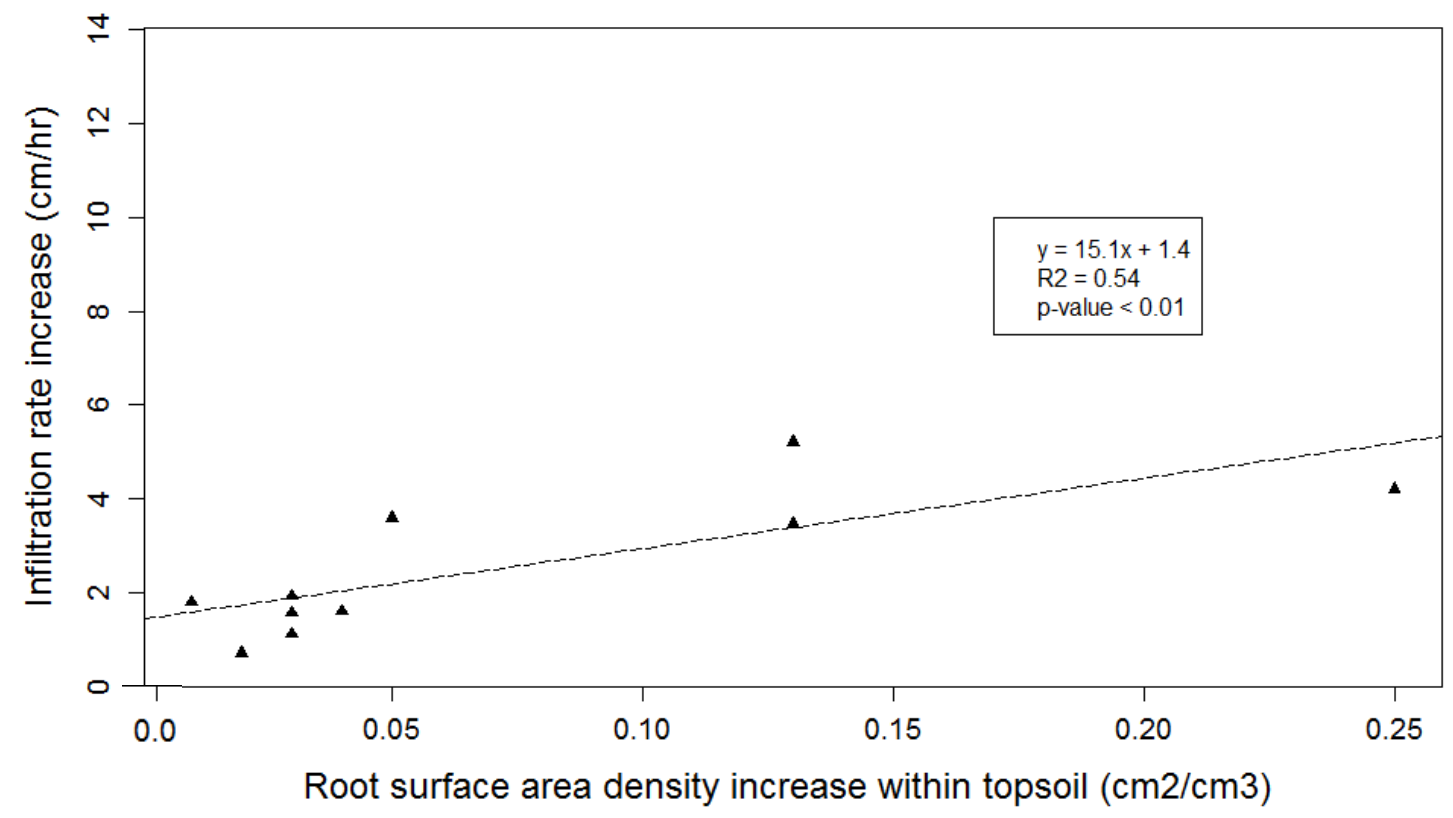

Figure 20: Root surface area density (RSAD) increase and infiltration rate increase (from J-F to M-J 2014) within 10 bioswales in Portland, OR. 
Root Volume Density (RVD): RVD increased within the topsoil and $1 \mathrm{~m}$ profile at the following depths: 0-8, 26-34, 60-85 cm (Fig. 21, Table 3). RVD was greater within the topsoil compared to the subsoil during J-F and M-J 2014 (Table 3). RVD within the topsoil and infiltration rate showed a positive relationship $\left(\mathrm{R}^{2}=0.42\right.$, Fig. 22$)$.

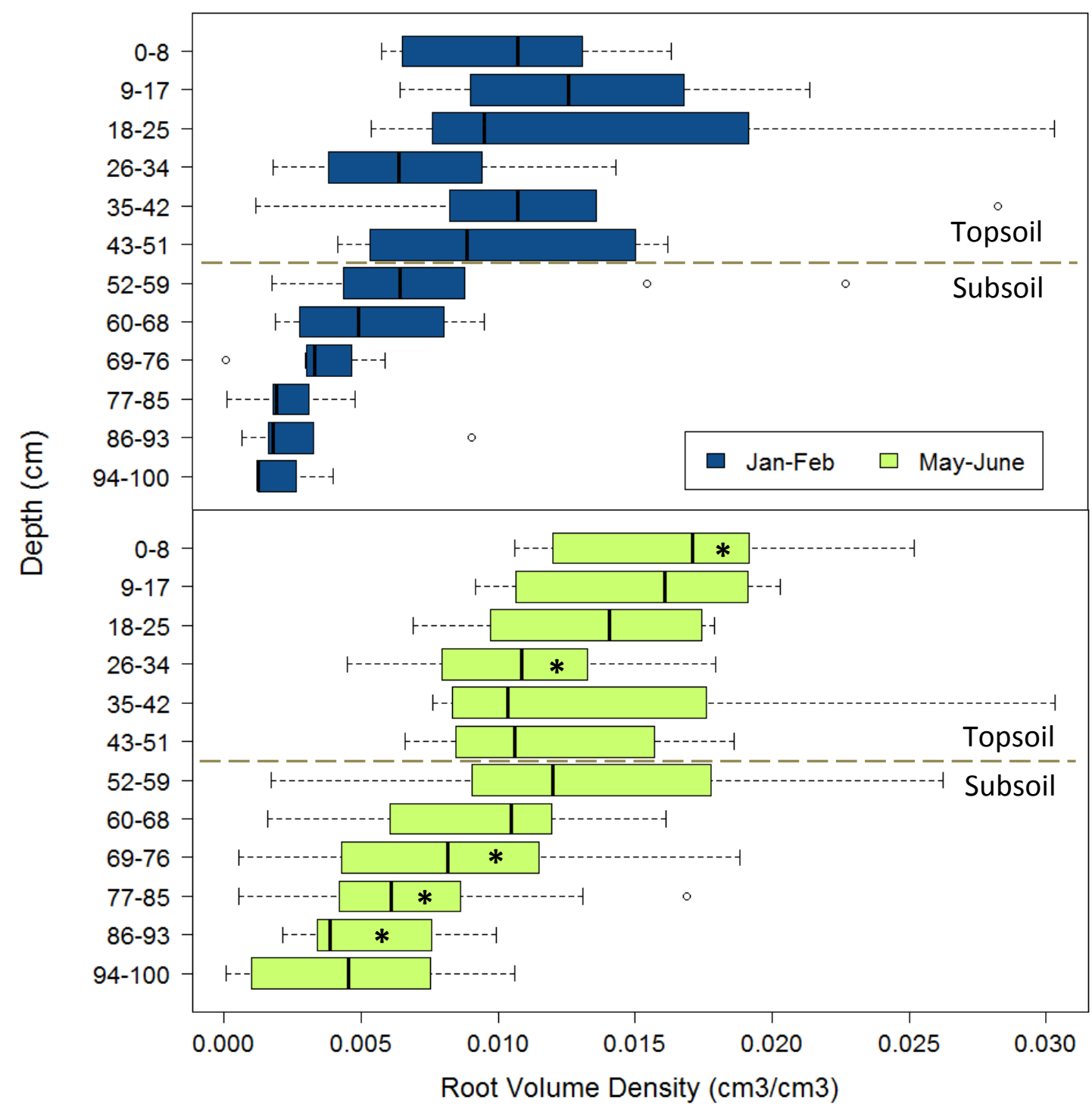

Figure 21: Root volume density J-F (top) and M-J (bottom) by $8.5 \mathrm{~cm}$ depth increments. *Significant increase in root volume density from J-F (top) to M-J (bottom) using a t-test (unequal variance, normal distribution). 


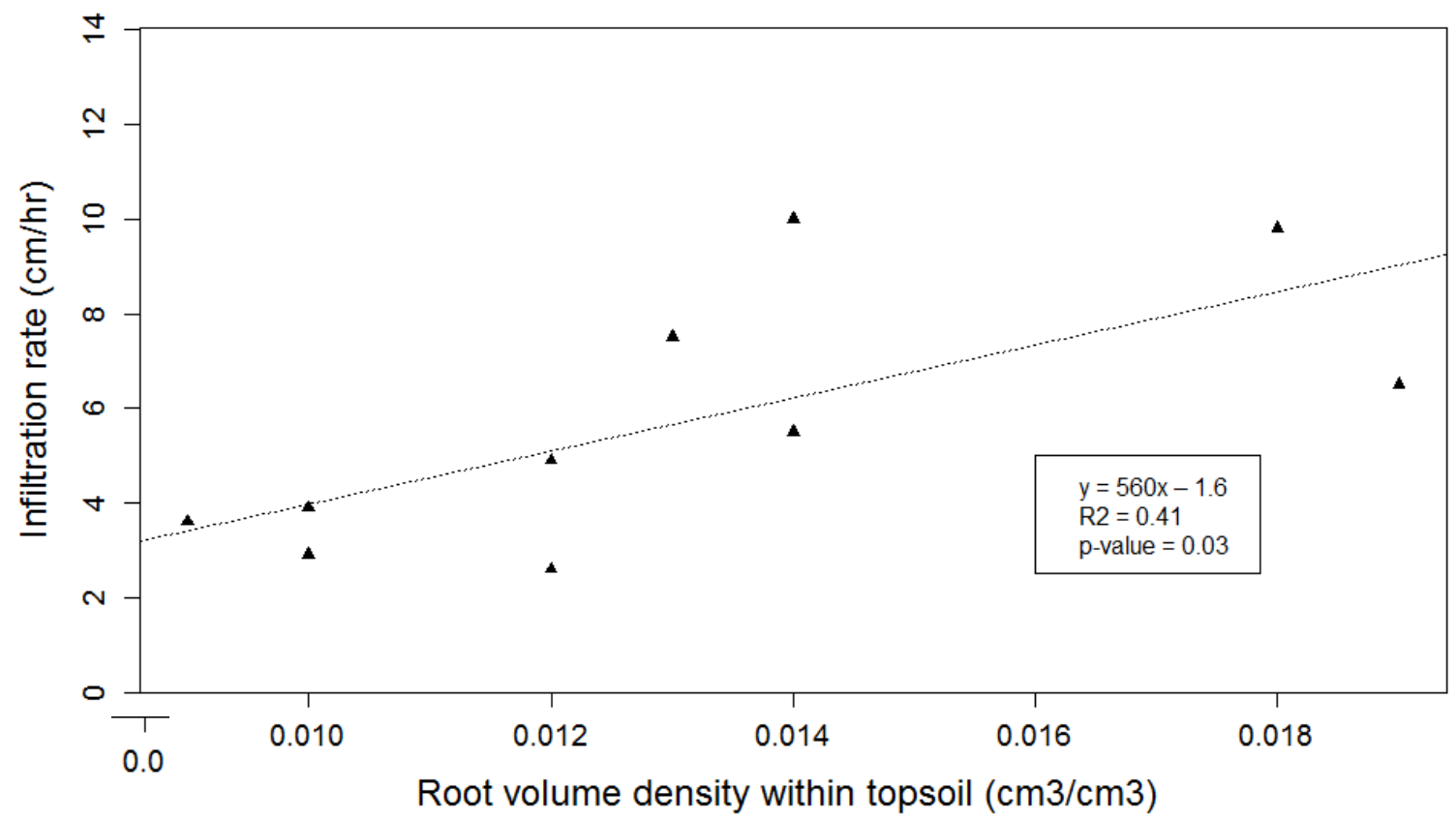

Figure 22: Root volume density $\left(\mathrm{cm}^{3} / \mathrm{cm}^{3}\right)$ within topsoil $(0-50 \mathrm{~cm}$ depth) and infiltration rate during M-J 2014 within 10 bioswales in Portland, OR. 
Root Length Density (RLD): RLD increase was shown from the 60 to $93 \mathrm{~cm}$ depths from J-F or M-J 2014 (Fig. 23, Table 3). RLD was greater within the topsoil compared to the subsoil during J-F and M-J 2014 (Table 3). RLD showed no relationship with infiltration during J-F or M-J 2014. 


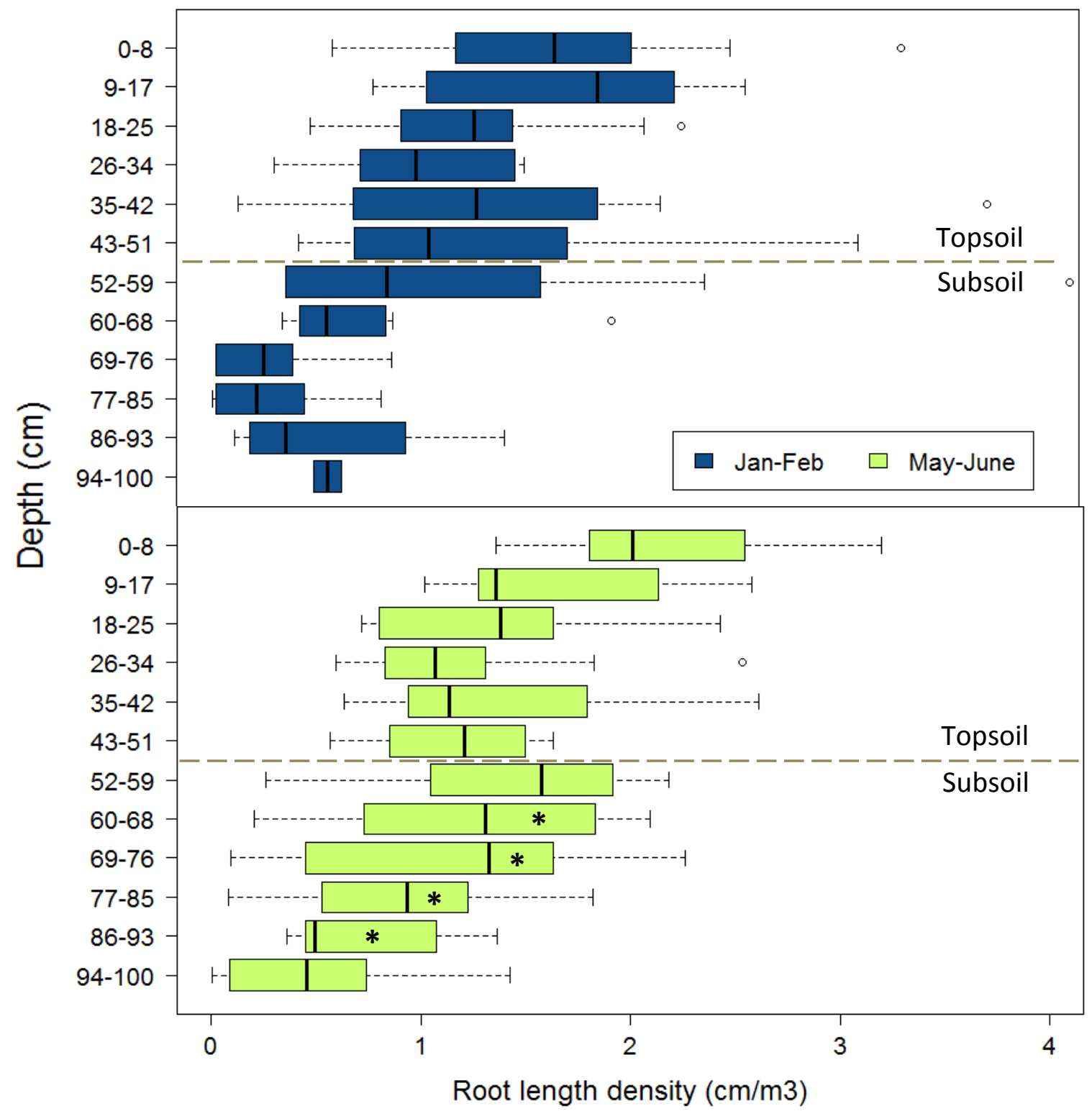

Figure 23: Root length density (RLD) J-F (top) and M-J (bottom) by $8.5 \mathrm{~cm}$ depth increments. *Significant increase in RLD from J-F (top) to M-J (bottom) using a t-test (unequal variance, normal distribution) and Wilcoxon rank sum test. 
Specific Root Length (SRL): SRL showed no increase from J-F to M-J 2014 at any depth increments (Table 3) and showed no relationship with infiltration during J-F or M-J 2014.

Relationship between Multiple Root Characteristics and Infiltration Rate: Limited evidence suggested a positive relationship between multiple root characteristics and infiltration rate during late spring (Table 4). Within the topsoil, RMD and RD explained $77 \%$ of the infiltration rate variation. For every $1.0 \mathrm{~mm}$ increase in RD within the topsoil, infiltration rate increased between 10.4 and $31.9 \mathrm{~cm} / \mathrm{hr}$.

\section{Relationship between Infiltration Rate and Installation, Vegetation, Soil,} Precipitation, and Other Environmental Characteristics (Table 1): No relationship with infiltration rate was found between precipitation event size and duration, facility age, slope, facility area, catchment area, sizing, groundwater depth, distance to closest tree or building, J. patens or understory plant density, topsoil and subsoil bulk density, and topsoil (except maximum infiltration rate) and subsoil percent fines (average, J-F, M-J, minimum, or maximum). Also, no relationship or difference was found between the five facilities with one tree versus five facilities with two trees when comparing any of the root variables, infiltration rate (average, J-F, M-J, minimum, or maximum), or installation variables.

Table 4: Stepwise regression of six root characteristics and infiltration rate during M-J. Root characteristics include root mass density (RMD) and root diameter (RD), and root volume density (RVD).

\begin{tabular}{llccccccc} 
& & & \multicolumn{3}{c}{ Confidence Interval } & \multicolumn{3}{c}{ Adjusted } \\
\cline { 5 - 7 } Depth & Root Characteristic Estimate & Std. Error & $2.5 \%$ & $97.5 \%$ & p-value & R-squared & p-value \\
\hline \multirow{2}{*}{ Topsoil } & RMD & 2.2 & 0.8 & 0.7 & 3.8 & 0.025 & 0.77 & 0.002 \\
& RD & 21.1 & 5.4 & 10.4 & 31.9 & 0.006 & & \\
\hline
\end{tabular}




\section{Discussion}

Winter Infiltration: It is likely that the large amounts of winter precipitation played a role in reducing infiltration rates during J-F 2014 and October 2014 to February 2015 as shown in similar work (Emerson and Traver 2008, Selbig and Balster 2009, Lewellyn et al. 2016). In addition, longer duration of precipitation, lower evapotranspiration, and longer duration of SBF ponding, resulted in fewer days for SBF soil to dry. During several root sampling days in J-F 2014, I was unable to extract a usable core due to the high water content. It's possible the lower amount of shrinking and swelling of the soil during the winter resulted in fewer macropores being formed for preferential flow (Rasse et al. 2000). It is also unlikely that the average J-F 2014 temperature of $8.5^{\circ} \mathrm{C}$ played a large part in reducing infiltration, due to increasing viscosity (Emerson and Traver 2008), as this value was not much lower than the average M-J 2014 temperature of $12.5^{\circ} \mathrm{C}$.

Seasonal Precipitation and Infiltration: The change in monthly precipitation, and thus stormwater inflow into these 10 SBFs, from one month to the next, only corresponded with a decrease in infiltration rate in October 2014. The September 2014 precipitation $(1.1 \mathrm{~cm})$, and thus stormwater inflow into these $\mathrm{SBFs}$, was much lower than the previous ten-year monthly average $(4.2 \mathrm{~cm})$. This low amount of September precipitation may have contributed to the high infiltration rate $(7.0 \mathrm{~cm} / \mathrm{hr})$. The October 2014 precipitation $(13.6 \mathrm{~cm})$ was approximately twice as much as the previous ten-year monthly average $(7.8 \mathrm{~cm})$. The large amount of October precipitation may have contributed the infiltration rate decrease from September to October 2014 (7.0 to 4.5 
$\mathrm{cm} / \mathrm{hr})$. Similarly, the precipitation during February $(14.7 \mathrm{~cm})$ and March $(22.4 \mathrm{~cm}) 2014$ was approximately twice as much as the previous ten year monthly averages ( 7.9 and 11.5, respectively). However, this larger amount of precipitation corresponded with an increase in infiltration rate from February to March 2014 (3.6 to $5.6 \mathrm{~cm} / \mathrm{hr}$ ). Typically an increase in soil moisture decreases infiltration rate (Nassif and Wilson 1975). This suggests other factors were increasing the infiltration rate, such as macropore flow from biological activity (Greene 2008) which increases in early spring.

Increase in Late Spring Root Characteristics and Infiltration: Several factors likely contributed to the increase in root characteristics primarily at the $60-85 \mathrm{~cm}$ depths, and the corresponding increase in infiltration. During M-J 2014, the smaller precipitation amounts, shorter duration of precipitation, shorter duration of SBF ponding, and greater evapotranspiration, likely resulted in greater drying and shrinking of the subsoil and topsoil. During this period, I seldom extracted root cores that were saturated with stormwater. This drying likely created more macropores and aeration within the soil. This combined with greater temperatures (Eissenstat and Yanai 1997) likely provided an opportunity for greater root growth (Mitchel 1995). It's likely that the increase in RD, RSAD, RVD, and RLD during M-J 2014 near the top of the subsoil was a result of vegetation attempting to utilize stormwater during an increasingly dry period. The increase in RMD within the $1 \mathrm{~m}$ profile (66\%) was similar to the temperate wetland plant root turnover rate (58\%) reported by Gill and Jackson (2000). This late spring root increase was similar to the increase in root production found in spring (Pregitzer et al. 2000) and summer RMD peak (Tufekcioglu et al. 1999) wetland studies. The 
corresponding large root growth and increase in infiltration rate found during late spring in this work, was similar to Emerson and Traver (2008), Selbig and Balster (2009), and Hatt et al. (2009).

Juncus patens versus tree root effect on infiltration: It is likely that within the topsoil Juncus patens roots contributed more than tree roots to infiltration rate. J. patens cover the most area within the SBFs studied and most of their root biomass resides within the topsoil (Olney et al. 2010). During preliminary investigations, removal of entire $J$. patens plant individuals from SBFs with similar size trees showed the majority of the $J$. patens roots resided within the topsoil. Most of the tree roots were found to reside at least $30 \mathrm{~cm}$ away from the root crown of the J. patens individuals leaving much less topsoil volume for the tree roots to occupy compared to the J. patens roots. Also, the majority of the $J$. patens roots examined were greater than $0.3 \mathrm{~mm}$ in diameter, the diameter at which point macropore flow is believed to start (Jarvis 2007). Thus, J. patens roots likely contributed most to the relationship between the root characteristics (RMD, RSAD, and RD) and infiltration rate found within the topsoil.

Tree roots likely contributed to the infiltration rate increase as well, even though no relationship with infiltration rate and the above ground tree characteristics were shown. Trees in this study likely experienced healthy root growth as ponding only occasionally lasted greater than 48 hours in the winter (time at which damage to fine roots has been shown to start, Bartens et al. 2009). Also, tree measurements taken before and after this study showed a steady average DBH growth of approximately $20 \%$. This is considered healthy growth for stormwater trees of this size (MacDonagh 2011 and 2015). 
The average tree size (6.3 cm average DBH, 5-10 year old trees) was much greater in this study compared to Bartens et al. work $(1-2 \mathrm{~cm}$ trunk diameter at $15 \mathrm{~cm}$ above soil line in greenhouse pots) who showed a relationship with RMD and hydraulic conductivity. However, the average tree size in this work was far below the recommended size $(>76 \mathrm{~cm}$ DBH) to maximize hydrologic processes such as precipitation interception and transpiration (MacDonagh 2015). The evenly spaced tree placement (one tree in the middle or two trees evenly spaced) within the 10 SBFs likely optimized the topsoil rooting volume which is critical for healthy root growth (Lindsey and Bassuk 1991). Tree evapotranspiration in this study likely did not contribute to a large percent of the infiltration rate, even during the late spring. The average tree size $(6.3 \mathrm{~cm}$ average $\mathrm{DBH})$ and age (5-10 year old) was much smaller in comparison to studies showing trees $(1.4 \mathrm{~m}$ average $\mathrm{DBH},>15$ years old) contributing a large percent (46 to $72 \%$ ) to the total bioswale water outputs via transpiration. Also the short ponding time ( $<48$ hours) did not allow trees much time to contribute to infiltration rate. However, this work does support the view of many researchers (e.g., MacDonagh 2015) that trees are one of the best adapted growth forms for bioswales, due to their large, spreading, opportunistic root systems (Scharenbroch et al. 2016) and the several roles they play in stormwater management (Breen et al. 2004).

Root Mass Density (RMD): Vegetation investment in root construction and maintenance appears to have a relationship with infiltration rate within these SBFs. Root mass is considered proportional to the construction and maintenance (cost) within roots, as opposed to thinner, longer roots (Eissenstat and Yanai 1997). The investment in 
greater root mass likely provides a greater amount of tissue (e.g. lateral meristem) for primary and secondary root growth (e.g. root thickening) building root size (e.g. RD, RSAD, and RVD), pushing soil away from roots, and creating larger rhizopore (space between root and soil) volume for macropore flow. In primary growth, it's possible the more dense components, such as the Casparian strip in the endodermis, provide greater structural integrity for the root (Gregory 2006). Moreover, during environmental stress such as drought and toxic metals, Casparian strips are known to form within the hypodermis as well, forming a barrier to the flow of water and nutrients (Hose et al. 2001). This greater mass and root rigidity may increase the rhizopore volume increasing macropore flow.

The fact that RMD showed several relationships (1m, topsoil, subsoil, J-F to M-J 2014 increase) with infiltration rate, may be explained by the large range of 0.3-2.2 $\mathrm{Kg} / \mathrm{m}^{3}$ in RMD. These values overlapped and extended well above RMD values of 0.1 $0.7 \mathrm{Kg} / \mathrm{m}^{3}$ shown by Bartens et al. (2008) to have a relationship with hydraulic conductivity in similar clay loam soil.

The lack of evidence for a relationship between RMD and infiltration rate during the winter of 2014 was likely due to several factors relating to inundated soils (above). Infiltration rates have been observed to increase with greater RMD when rates were measured after legume (Trifolium sp.) root decomposition in late fall (Disparte 1987). Additionally, Disparte (1987) showed similar RMD values $\left(0.03-0.6 \mathrm{~kg} / \mathrm{m}^{3}\right)$ compared with those found during J-F in this work $\left(0.03\right.$ to $\left.0.4 \mathrm{~kg} / \mathrm{m}^{3}\right)$. Also, the sandy loam topsoil was similar among these two studies. Thus, it is likely that other factors, such as 
inundated soils, muted any root enhanced infiltration within SBF during winter 2014 in this study.

Root Diameter $(R D)$ : RD also represents a large investment in root structure which appears to have a strong relationship with infiltration rate during late spring (M-J 2014). RD is one of the strongest determinants of life span (Eissenstat et al. 2000) suggesting roots with greater RD are a significant investment for vegetation. $\mathrm{RD}$ was the only root characteristic to show an increase (J-F to M-J 2014) within the $1 \mathrm{~m}$ soil profile, topsoil, and subsoil, and showed a relationship with infiltration rate and the ratio of the topsoil to subsoil RD. This ratio ranged from 1.0-1.6, similar to the ratio (1.0-2.0) Zedler (2007) suggested would be well suited for infiltration. The shrinking and swelling of roots during the late spring within the topsoil may have resulted in macropores and preferential flow along root pathways which extended into the subsoil. This may occur most during secondary growth within the tree roots (Juncus monocots lack secondary growth) as vascular tissue divides and expands in the radial direction (Gregory 2006). $\mathrm{RD}$ appears to have a greater effect on infiltration rate compared to other root characteristics. When determining the relationship of multiple root characteristics and infiltration rate, $\mathrm{RD}$ showed the greatest infiltration rate increase for every increase in $\mathrm{RD}$ within the topsoil. Also, $\mathrm{RD}$ within the topsoil $\left(\mathrm{R}^{2}=0.57\right)$ and for the ratio of topsoil to subsoil $\left(\mathrm{R}^{2}=0.55\right)$ showed a greater effect on infiltration rate compared to $\mathrm{RMD}\left(\mathrm{R}^{2}=\right.$ $0.52)$ and $\mathrm{RVD}\left(\mathrm{R}^{2}=0.42\right)$. However, comparing $\mathrm{R}^{2}$ among independent variables should be conducted with caution as a narrower range of independent variables (root characteristics) can result in a smaller $\mathrm{R}^{2}$ (Gotelli and Ellison 2004). The data ranges for 
this work (RMD 0.4-2.2 kg/m³, RD 1.1-1.4 mm, and RVD 0.9-1.5 $\mathrm{cm}^{3}$ ) were similar to those found in other studies (Gregory 2006).

During J-F 2014, it is possible that the range in root RD $(0.8-1.1 \mathrm{~mm})$ was just below the threshold for increasing infiltration rate, as shown during M-J 2014 when RD (1.0-1.2 mm) showed a relationship with infiltration rate. It's possible that this range is necessary for creating macropores ( $>0.3 \mathrm{~mm}$ diameter for macropore flow, Jarvis 2007) via several mechanisms such as growth, shrinking and swelling, exudates, and death. However, several other factors relating to inundated soils (above) likely contributed or muted any effect RD may have had with infiltration during J-F 2014.

Root Surface Area Density (RSAD): Similar to RMD, RSAD represents a large investment in root structure that appears to have a lesser but significant effect on infiltration rate. Even though RSAD increased (J-F to M-J 2014) within the entire $1 \mathrm{~m}$ soil profile and at several topsoil and subsoil depths, a relationship $\left(\mathrm{R}^{2}=0.54\right)$ with infiltration rate increase (J-F to M-J 2014) was only found for RSAD increase within the topsoil during M-J 2014. This may have been due to the low RSAD range (0.2-0.7 $\left.\mathrm{cm}^{2} / \mathrm{cm}^{3}\right)$ during late spring compared what Zhou and Shangguan found (1.5-1.65 $\left.\mathrm{cm}^{2} / \mathrm{cm}^{3}, 2007\right)$ when they showed a strong relationship $\left(\mathrm{R}^{2}=0.92\right)$ with RSAD and infiltration rate.

Root Volume Density (RVD): Similar to RSAD, RVD also represents a large investment in root structure (Eissenstat and Yanai 1997) which appears to have a slight relationship with infiltration rate during late spring (M-J 2014). RVD showed a similar 
increase as RSAD at several depths and a relationship with infiltration rate within the topsoil.

Root Length Density (RLD): The low RLD values may partially explain why no relationship was shown with infiltration rate. During J-F 2014, almost all the J-F (0.1-1.4 $\left.\mathrm{cm} / \mathrm{cm}^{3}\right)$ and most of the M-J $\left(0.1-1.9 \mathrm{~cm} / \mathrm{cm}^{3}\right)$ RLD values were below values shown by Lange et al. (1.1 to $\left.1.5 \mathrm{~cm} / \mathrm{cm}^{3}, 2009\right)$ to increase drainage among three tree species in similar soils, including loam, clay loam, sandy clay loam.

Specific Root Length (SRL): The lack of relationship between SRL and infiltration rate, and no SRL increase (J-F to M-J 2014), suggests the relationship between root length and mass (i.e. root density) has little effect on infiltration rate in SBFs. Unlike all the other root characteristics measured, SRL showed no difference in topsoil vs subsoil during either J-F or M-J 2014. Several plant species show an increase or decrease in SRL to optimize resource uptake (Montagnoli et al. 2014). This work suggests Juncus are not changing the SRL, or root density, to adapt from the inundated winter period to a dryer late spring period. However, only roots greater than $0.3 \mathrm{~mm}$ were used in this study so it is possible that SRL for finer roots changed between seasons.

Relationship between Multiple Root Characteristics and Infiltration Rate: RMD and RD may have a synergistic effect on infiltration rate. The greater RMD and RD, and thus structural root components (Eissenstat and Yanai 1997), may provide resistance against the compression of soil within the rhizosphere (Ghestem et al. 2011). The different soil properties of the topsoil and subsoil likely contribute to the greater influence on infiltration rate by RD within the topsoil. The lower bulk density and fines 
content of the topsoil likely allows for the greater RD within the topsoil. Also, the $0.5 \mathrm{~m}$ of friable/loose topsoil, which consists mainly of sand and compost, likely provides only moderate impedance for root radial growth (larger RD). Conversely, the greater bulk density and fines content of the subsoil likely impedes radial root growth. Thus, the longer root lengths may provide greater opportunity for preferential flow of stormwater within the subsoil.

Conclusions: This work strongly suggests plant roots can increase infiltration, and thus the primary functions of stormwater bioretention facilities (SBFs). Specifically, plant investment in root mass density (RMD) and root diameter (RD), and to a lesser degree root surface area density (RSAD) and root volume density (RVD), within the $1 \mathrm{~m}$ soil profile may increase infiltration rate in SBFs within late spring. Also, limited evidence of multiple root characteristics (RMD and RD) increasing infiltration was shown. Although the greatest increase from J-F to M-J 2014 for most root characteristics occurred within the subsoil (RMD, RSAD, RVD, root length density (RLD)), surprisingly several of the relationships between root characteristics and infiltration rate were shown within the topsoil (RMD, RSAD, and RD). 


\title{
Chapter 3
}

\section{Root Characteristics and Infiltration among Stormwater Bioretention Facilities with Different Vegetation Assemblages}

\begin{abstract}
Within stormwater bioretention facilities (SBFs), vegetation selection can play an important role in performance. Studies show variation in root morphology and distribution among plant types (i.e. trees) and for individual species. Studies also show how root biomass can peak during different seasons among species/locations. Larger biomass plant types have also been shown to enhance infiltration rate, one of the most important SBF performance measures. The prevalent use of vegetation in SBFs provides the opportunity to study in situ how various plants may affect infiltration rate. No research has shown how different root characteristics may vary from different plant types/species, how these differences can occur at various depths, and how root characteristics may affect infiltration rate within currently functioning SBFs. I hypothesized that: 1) larger-root SBFs exhibit greater infiltration during J-F and M-J periods compared to the smaller-root facilities, 2) the increase in root characteristics and infiltration rate from $\mathrm{J}-\mathrm{F}$ to $\mathrm{M}-\mathrm{J}$ is greater in the larger-root SBFs compared to the smaller-root SBFs, and 3) root surface area density within Juncus + tree SBFs shows a
\end{abstract}


positive relationship with infiltration rate in late spring. Preliminary data (Chapter 1) within inner Southeast Portland suggested root mass density (RMD) was lowest during January to February (J-F) and highest during May to June (M-J). Also, preliminary data showed infiltration rate was lowest from December to February and highest from June to August. Five larger-root (Juncus sp. dominant + tree) and five smaller-root (Carex species dominant) SBFs were selected within inner Southeast Portland controlling for as many factors as possible. Infiltration rates were recorded using water depth data loggers from January 2014 to February 2015. Three root cores per facility were collected to a depth of 1 m during J-F 2014 and M-J 2014. Root depth sections of approximately $8 \mathrm{~cm}$ were analyzed using WinRHIZO for six root characteristics shown to have a relationship with infiltration rate, or similar metric. These root characteristics include: root mass density (RMD), root diameter (RD), root surface area density (RSAD), root volume density (RVD), root length density (RLD), and specific root length (SRL). Juncus showed greater values compared to Carex SBFs for four root characteristics during J-F (RMD, RD, RVD, and SRL) and five root characteristics (RMD, RD, RSAD, RVD, RLD) during M-J 2014. These five root characteristics within Juncus SBFs also showed a greater increase (J-F to M-J 2014) compared to Carex SBFs, which showed no root increase during this period. Juncus SBFs showed greater infiltration rate compared to Carex SBFs during M-J 2014, and for an increase in infiltration from J-F and M-J 2014. Four Juncus root characteristics (RMD, RSAD, RD, and RVD) and one Carex root characteristic (RSAD) showed a positive relationship with infiltration rate during M-J 2014. RMD increase (J-F to M-J 2014) within Juncus SBFs was the only root 
characteristic to show a positive relationship with infiltration rate increase within the $1 \mathrm{~m}$ soil profile and topsoil. This work demonstrates vegetation with larger root characteristics can increase infiltration more than vegetation with small root characteristics within fully functional SBFs.

\section{Introduction}

Vegetation selection within stormwater bioretention facilities (SBFs) can play an important role in pollutant retention (Hatt et al. 2009, Read et al. 2010) and stormwater flow (Scharenbroch et al. 2016). A diversity of vegetation is used in SBFs (Fairfax Co. 2007) with common plant types including trees, shrubs, sedges, and rushes (Read et al. 2008). Many plant species used in SBFs include wetland species due to their ability to tolerate prolonged flooding and drought (Roy-Poirier et al. 2010). Trees have been proposed to be the best adapted growth form for bioswales because of their large, spreading, opportunistic root systems (Scharenbroch et al. 2016) and they play many roles in stormwater management (Breen et al. 2004). Scharenbroch et al. (2016) showed transpiration by trees accounted for 46-72\% of total water outputs within a Midwestern U.S. parking lot from May to October. However, many plant species used in SBFs are not as well suited as other plant species depending on the function being optimized (e.g. aesthetics).

Studies show variation in root morphology and distribution among and within plant types (e.g. trees, Gill and Jackson 2000, Hodge et al. 2009) and for individual species (Hodge et al. 2006). Zedler (2007) found 40 similar wetland species had little 
similarity in root characteristics (root: shoot ratio, average deep root mass, deep: upper root ratio). Selbig and Balster (2009) found that between two precipitation gardens with the same soil, roots in turf-grass were limited to the upper A and Bt horizons, whereas prairie-grass roots were present in all horizons with a total dry weight of almost double the turf-grass. Moreover, the prairie-grass specific root length (SRL) were $23 \%$ lower and $14 \%$ higher in the A and Bt horizons, respectively, compared to the turf grass. Comas and Eissenstat (2009) found that SRL varied the most, compared to other root characteristics, among 25 co-existing North American forest species.

Studies show below-ground biomass of most wetland plants varies seasonally and peaks in the fall, winter, or spring/summer. Studies showing a spring/summer belowground biomass peak include: April peak in natural wetlands ( $P$. australis, T. Latifolia, and Carex species) in the Netherlands (Meuleman et al. 2002), greatest root mass density in June-July followed by a marked decrease in late summer (Spartina altemiflora) within a Maine salt marsh (Valiela et al., 1976), an increase from May to August followed by a decrease in September (Spartina anglica) within a Netherlands salt marsh (Hemminga et al. 1996), an August peak in switchgrass RMD (Panicum virgatum, Tufekcioglu et al. 1999), and a summer increase for Sparganium and Phragmites in Iowa Marshes (Van Der Valk and Davis 1978). Hemminga et al. (1996) attributed a spring-to-summer root biomass peak to storage of underground carbohydrate reserves for use in fall/winter. Studies showing a fall and/or winter below-ground biomass peak include: greatest biomass productivity during October in Typha angustifolia in Texas (Hill 1987), a December peak in wastewater wetlands (P. australis) in the Netherlands (Meuleman et al. 
2002), a July-August annual biomass low (Typha latifolia) in a Wisconsin freshwater marsh (Smith et al. 1988), a winter peak with a biomass low in July (Carex rostrate) in Minnesota (Bernard 1974), and a mid-summer depression (50\% lower than winter, Typha Latifolia) within a Wisconsin Marsh (Smith et al. 1988). Several studies attribute the higher fall or winter root biomass to translocation or transport of nutrients from senescing leaves and shoots to the rhizome-root system (Meuleman et al. 2002).

Plant types have been shown to differ in their ability to enhance infiltration rate. Zedler (2007) found 20 wetland species exhibited a large range in the upper and lower root biomass ratio of 0.5 to 14.0. She suggested some assemblages with greater lower root biomass are more suitable for enhancing infiltration. Within columns filled with soil and plants, the tree Melaleuca ericifolia, with a large percent of coarse roots $(>2 \mathrm{~mm}$ diameter), was the only treatment to increase hydraulic conductivity over a 19-month period compared to smaller plant types (Carex apressa, Dianella revoluta, Microleana stipoides, and Leucophyta brownii) and the control with no vegetation (Le Coustumer et al. 2012). Bharati et al. (2002) found the cumulative infiltration over a 1-hr period was five times greater under vegetation buffers, such as silver maple, than under cultivated fields and pastures. Devitt and Smith (2002) showed that water penetrated more deeply in vegetated plots versus non-vegetated controls. Infiltration was shown to be three times greater under individual bushes than in areas of no vegetation (Lyford and Qashu 1969). Li et al. (2004) found that simulated precipitation within a field of annual grasses resulted in higher infiltration than for perennial herbaceous grass plots. They attributed the lower bulk density created by the annual grasses as the main factor resulting in greater 
infiltration. Lange et al. (2009) found a positive correlation between root length and flow length claiming tree roots in soils represent the pore system that carries preferential infiltration. He recommended a root length density of $1 \mathrm{~cm} / \mathrm{cm}^{3}$ (not higher or lower) to maximize root preferential flow. Fischer et al. (2014) showed infiltration rate increased with the presence of legumes at the end of the growing season in September to October, but not in June.

The prevalent use of vegetation in SBFs provides the opportunity to study in situ how various plants may affect facility performance, such as infiltration rate. However, few studies have investigated if plant type or species choice optimizes SBF performance (Scharenbroch et al. 2016). Selbig and Balster (2009) showed rain gardens with similar soil conditions planted with shallow root turf grass had a lower median infiltration $(0.7$ $\mathrm{cm} / \mathrm{hr})$ than those planted with prairie species $(2.2 \mathrm{~cm} / \mathrm{hr})$ with uniform root distribution. They also showed that infiltration rate was greater during spring and summer when root growth is typically greatest. Greene (2008) showed that both plants and macrofauna (e.g. earthworms) increased hydraulic conductivity and stormwater storage compared to the non-vegetated controls in a small three year lysimeter study in SBF mesocosms. Denman et al. (2006) observed greater root length density (RLD) and height in trees receiving stormwater in comparison to tap water, although little difference in nutrient uptake was shown.

I hypothesized that: 3) The Juncus + tree assemblage (greater root biomass) exhibits greater root mass density and infiltration during winter and late spring periods compared to the Carex SBFs, 4) The increase in infiltration rate and root characteristics 
from winter to late spring is greater in the Juncus + tree SBFs compared to the Carex SBFs, and 5) root surface area density (RSAD) within Juncus + tree SBFs shows a positive relationship with infiltration rate in late spring.

Overall Approach: To determine if vegetation with larger-root characteristics within SBFs exhibit greater infiltration than vegetation assemblages with smaller-root characteristics, I compared five larger-root (Juncus p. dominant + tree) with five smallerroot facilities (Carex species dominant). I controlled for as many factors known to affect infiltration and root growth as possible, such as soil bulk density. Roots were sampled and quantified during winter and late spring 2014. Infiltration was measured using water depth gages during drawdown events following precipitation events from Jan 2014 to Feb 2015.

\section{Methods}

Inner southeast Portland, Oregon (Fig. 24), was selected for the study site as it contains approximately 130 SBFs with similar design, size, age, and environmental characteristics (e.g. subsoil bulk densities). Several characteristics, such as facility size, were used to select five larger root biomass SBFs (Juncus patens + Tree) and five smaller root biomass SBFs (Carex species, Table 5, Appendix B). Only five Carex and five Juncus patens + Tree SBFs were chosen as I was unable to locate more Carex SBFs within the area chosen that satisfied the selection criteria (Table 5). No facilities were selected whose soil bulk densities were so high as to impede root penetration $\left(1.8 \mathrm{~g} / \mathrm{cm}^{3}\right.$ for sandy loam topsoil and $1.55 \mathrm{~g} / \mathrm{cm}^{3}$ for clay loam subsoil, Table 5). 
Infiltration Measurements: Water level was recorded in every facility from January 2014 to February 2015 using U20 water level HOBO data loggers (Onset Computer Corp., Bourne, MA). This was done as preliminary data (Chapter 1) showed infiltration rate was lowest from December to February and highest from June to August. One data logger was installed in the approximate middle of each facility, approximately $10 \mathrm{~cm}$ below the subsoil within $3.2 \mathrm{~cm}$ diameter PVC tubes, and tubes were wrapped in cloth (grade 90 unbleached cheesecloth) to allow water through, but not sand and silt. The tubes were secured to the ground with stakes and hose clamps such that data loggers would not move. Water depth was recorded every five minutes on an interval of 75 days at which time data were downloaded using a portable data shuttle and data loggers were reset.

Data logger depth measurements were validated by simulating a water quality design storm (2.1 cm, NRCS Type 1A rainfall distribution, Merkel et al. 2016) or larger design storm ( $4.8 \mathrm{~cm}, 25-\mathrm{yr}, 6-\mathrm{hr}$ storm) depending on the infiltration capacity of the SBF. Nearby hydrants and a flow regulator were used to provide inflow to a depth greater than $7 \mathrm{~cm}$ and the actual infiltration rate (water depth using tape measure every 5 minutes) was compared with data logger values. 


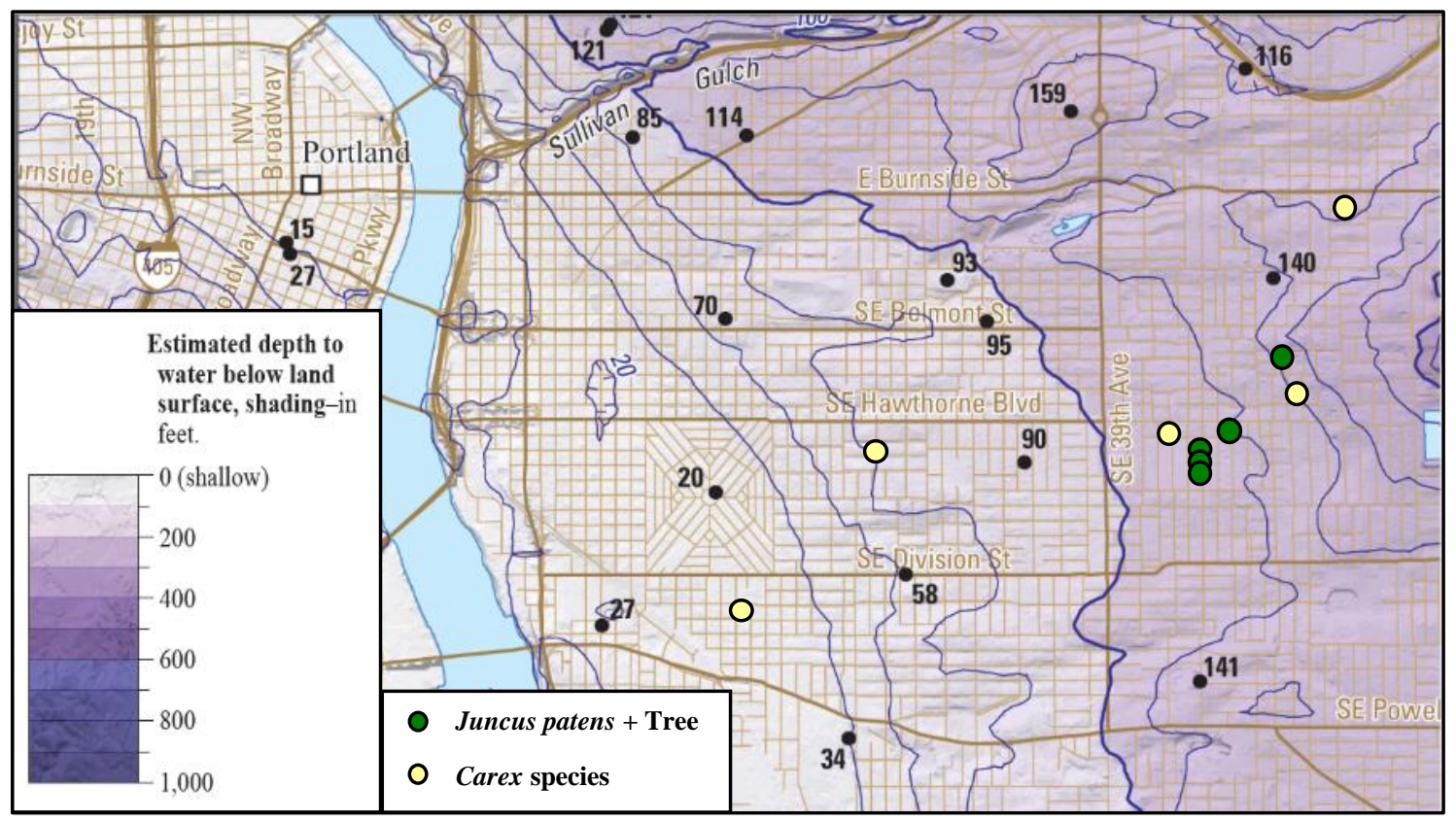

Figure 24: Location of five larger-root biomass stormwater bioretention facilities (Juncus patens + Tree, dark green circles) and five smaller-root biomass stormwater bioretention facilities (Carex species, light yellow circles) in Portland, OR (Snyder 2008 , estimated depth to ground water and configuration of the water table in the Portland, OR). 
Table 5: Installation, vegetation, root, soil, and other environmental characteristics, ranges, and associated citations of selected stormwater bioretention facilities.

\begin{tabular}{|c|c|c|c|c|}
\hline Category & Criteria & $\begin{array}{c}\text { Juncus + Tree } \\
\text { Range and Average }\end{array}$ & $\begin{array}{c}\text { Carex } \\
\text { Range and Average }\end{array}$ & Citation \\
\hline \multirow{5}{*}{$\begin{array}{l}\text { Facility } \\
\text { installation }\end{array}$} & Facility size $<1$ standard deviation from mean of inner SE & & & \\
\hline & Portland $\left(11-39 \mathrm{~m}^{2}, 31 \mathrm{~m}^{2}\right)$ & $13.7-18.9,16.2 \mathrm{~m}^{2}$ & $7.4-29.6,16.2 \mathrm{~m}^{2}$ & Hart 2012 Unpublished data \\
\hline & Sizing: 2-15\% Range, $6.5 \%$ Target & $4.4-9.8,5.8 \%$ & $4.1-6.3,5.1 \%$ & SWMM 2014, Stevens 2013 \\
\hline & Facility average age $>3$ years & 3.4-3.6, 3.5 years & 3.0-3.8, 3.3 years & Selbig and Balster 2009 \\
\hline & 0-6\% Slope (\% rise/run) & $0.1-1.6,0.9 \%$ & $1.0-2.8,1.7 \%$ & SWMM 2014 \\
\hline \multirow[t]{21}{*}{ Vegetation } & Similar number plant species & $3-5,4.4$ & $3-5,3.8$ & \\
\hline & \multirow{8}{*}{ Tree species } & Black Tupelo & \multirow{8}{*}{ none } & \\
\hline & & (Nyssa sylvatica) & & \\
\hline & & Leprechaun Ash & & \\
\hline & & (Fraxinus pennsylvanica) & & \\
\hline & & Imperial Honeylocust & & \\
\hline & & (Gleditsia triacanthos) & & \\
\hline & & Canada Red Chokecherry & & \\
\hline & & (Prunus virginiana) & & \\
\hline & \multirow{12}{*}{ Understory species } & Blue-Grey Rush & Tufted Hair Grass & \\
\hline & & (Juncus patens) & (Deschampsia cespitosa) & \\
\hline & & Kelsey Dogwood & Kelsey Dogwood & \\
\hline & & (Cornus sericea) & (Cornus sericea) & \\
\hline & & Soft Rush & Soft Rush & \\
\hline & & (Juncus effusus ) & (Juncus effusus) & \\
\hline & & Dwarf Heavenly Bamboo & Dwarf Heavenly Bamboo & \\
\hline & & (Nandina domestica) & (Nandina domestica) & \\
\hline & & Orange Sedge & Orange Sedge & \\
\hline & & (Carex testacea) & (Carex testacea) & \\
\hline & & Gold Fountains Sedge & Gold Fountains Sedge & \\
\hline & & (Carex dollchostachya) & (Carex dollchostachya) & \\
\hline Roots & $\begin{array}{l}\text { Large range in root mass density and overlap with similar } \\
\text { studies }\end{array}$ & $0.4-1.1,0.6 \mathrm{~kg} / \mathrm{m}^{3}$ & $0.2-0.6,0.4 \mathrm{~kg} / \mathrm{m}^{3}$ & $\begin{array}{l}\text { Bartens et al. 2009, } \\
\text { Gregory } 2007\end{array}$ \\
\hline Topsoil & $\begin{array}{l}\text { Similar bulk density and }<3 \text { standard deviations of mean in } \\
\text { inner SE Portland range found in Portland facilities ( } 0.7 \text { - } \\
\left.1.5 \mathrm{~g} / \mathrm{cm}^{3}\right) \text { and below values shown to inhibit root growth } \\
\left(1.80 \mathrm{~g} / \mathrm{cm}^{3} \text { fine sandy loams) }\right.\end{array}$ & $1.1-1.5,1.3 \mathrm{~g} / \mathrm{cm}^{3}$ & $1.0-1.3,1.1 \mathrm{~g} / \mathrm{cm}^{3}$ & $\begin{array}{l}\text { Bowen 1981, } \\
\text { Hart } 2012 \text { Unpublished data }\end{array}$ \\
\hline Subsoil & $\begin{array}{l}\text { Similar bulk density and }<3 \text { standard deviations of mean in } \\
\text { inner SE Portland facilities }\left(0.9-1.6 \mathrm{~g} / \mathrm{cm}^{3}\right) \text { and below } \\
\text { values shown to inhibit root growth }\left(1.55 \mathrm{~g} / \mathrm{cm}^{3} \text { clay loam) }\right.\end{array}$ & $1.3-1.6,1.4 \mathrm{~g} / \mathrm{cm}^{3}$ & $1.3-1.5,1.4 \mathrm{~g} / \mathrm{cm}^{3}$ & $\begin{array}{l}\text { Bowen 1981, } \\
\text { Hart } 2012 \text { Unpublished data }\end{array}$ \\
\hline
\end{tabular}


Precipitation: To maximize the number of usable precipitation and infiltration events, a short minimum inter-event time (MIET, minimum number of dry minutes between separate precipitation events, Joo et al. 2014) was calculated. This was possible as the facility catchment sizes were small, from 7.4 to $29.6 \mathrm{~m}^{2}$ (Table 5, Appendix B). This resulted in cessation of surface, or overland, flow typically 5-10 min after cessation of a precipitation event. Only the overland flow, as opposed to direct flow (direct flow $=$ overland flow + interflow, Eq. 7, Dingman 2014) was used to calculate MIET (Joo et al. 2014). It was assumed that interflow did not enter the facilities due to the concrete walls along the sides of the facilities and distance to groundwater (base flow, Fig. 24, Table 5, and Appendix B):

$$
\text { Runoff }=\text { Overland Flow }+ \text { Interflow }+ \text { Baseflow }
$$

MIET was calculated using day, time and precipitation amount from the Sunnyside rain gage located an average of approximately $600 \mathrm{~m}$ or 10 blocks to the 10 selected SBFs (HYDRA City of Portland Water gage network, USGS 2015). For each facility, time of precipitation cessation and time of last inflow (slow trickle) into the facility was recorded. The difference between these two times was calculated. This value was then rounded up to next 5-minute interval (e.g. 18 rounded up to $20 \mathrm{~min}$ ). This was done to increase efficiency when determining precipitation event times and infiltration rates, and to ensure very little/no inflow was occurring during infiltration measurements (Table 5, Fig. 25). 


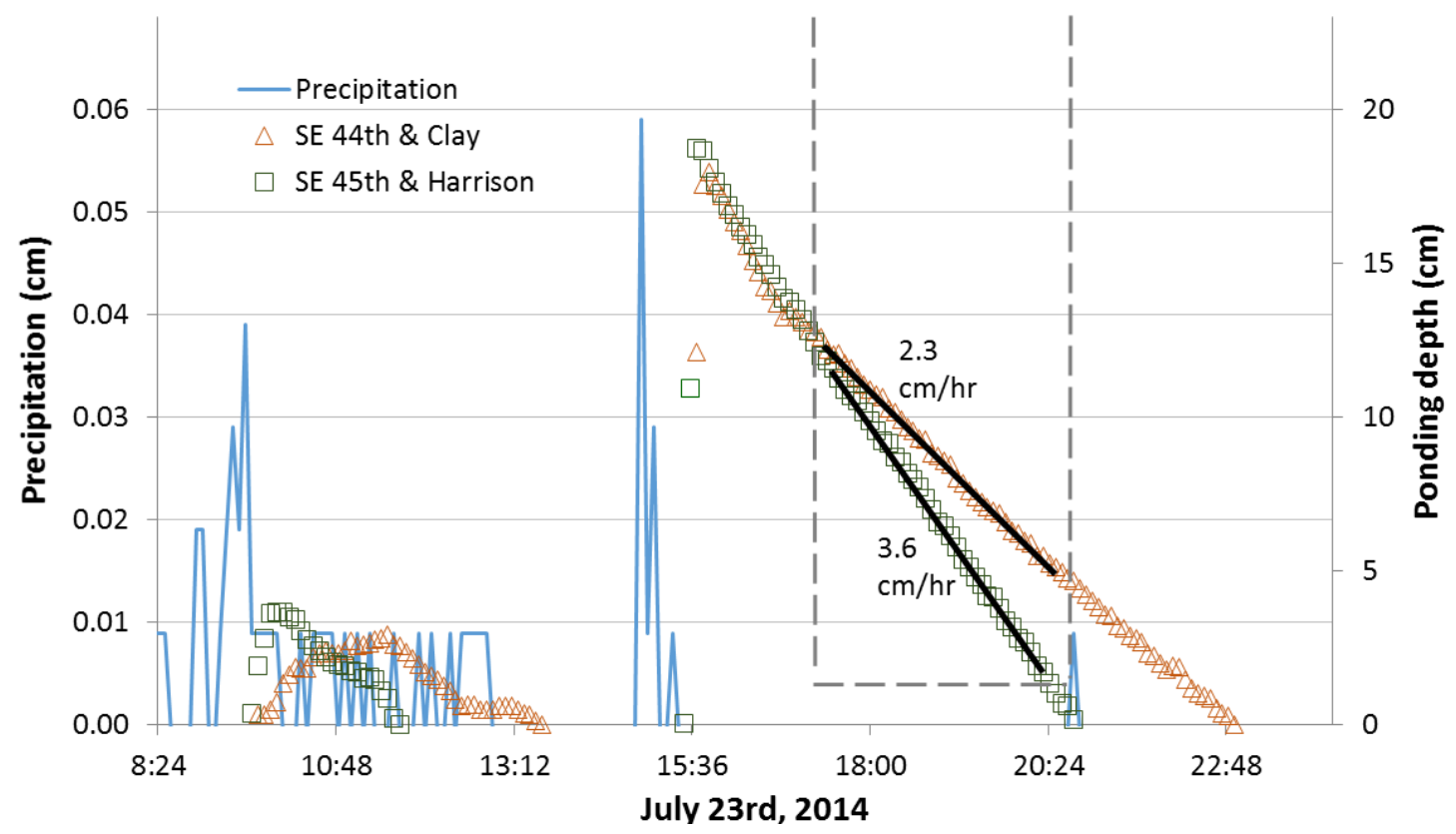

Figure 25: Precipitation, ponding depth (circles and boxes), and infiltration rate (black lines) in one Carex (triangles) and one Juncus (squares) bioswale in SE Portland, OR.

Infiltration Calculation: Infiltration rate was measured after each precipitation event that met the following criteria: 1) greater than $5 \mathrm{~cm}$ of ponding depth (stormwater surface in the $\mathrm{SBF}$ ) at the start of the infiltration event, 2) >30 min from the end of the MIET to the start of next precipitation event, and 3) greater than $1 \mathrm{~cm}$ ponding depth at the end of the infiltration event (Fig. 25). For example, $30 \mathrm{~min}$ of infiltration data recorded at a 5-min interval allowed for 6 ponding depth data points. Infiltration rate was determined by calculating the slope of the best fit linear regression for the drawdown data 
(Emerson and Traver 2008, Selbig and Balster 2009). Only infiltration rate slopes with $\mathrm{R}^{2}>0.95$ were used in case of any other inflow, such as a nearby car being washed. For all months measured, the average, minimum, and maximum infiltration rates were calculated. Infiltration rate determines both reduction in peak flow and pollutant capture, and is thus a good measure of performance (Hunt et al. 2012).

Root Sampling: Root samples were collected during two periods, January to February and May to June 2014. This was done as preliminary data (Chapter 1) within inner Southeast Portland suggested root mass density (RMD) was lowest during January to February (J-F) and highest during May to June (M-J). Soil cores were collected 1-3 days after a precipitation event so that all cores were collected at or near field capacity. This was done to increase the likelihood that the same volume of soil was being sampled for each soil core section as dry soil tends to shrink and wet soil expand. For each period, three 1-m deep cores per facility were collected (Selbig and Balster 2009) as negligible root densities had been recorded below this depth previously in Portland SBFs (Olney et al. 2010 unpublished data). Also, during winter it was difficult to get an accurate core sample below $1 \mathrm{~m}$ due to the saturation of the subsoil. For each facility, the coring location for each replicate was randomly selected within each of three equal sections (inlet, middle, and outlet) for a total of three replicates per facility. Auger locations were situated at least $0.3 \mathrm{~m}$ from bioswale walls to avoid facility edge effects. A soil recovery auger (AMS Inc., American Falls, ID) with a $25.4 \mathrm{~cm}$ x $8.4 \mathrm{~cm}$ core was used. This core kept the soil sample mostly intact while cutting some roots. This was appropriate as none of the root characteristics used in this study required completely intact roots, such as root 
length density (RLD, total length of roots per soil volume). After extraction, soil cores were left in the plastic liner and capped on both ends to avoid dehydration. Bentonite was poured into the empty auger holes and lightly compacted (Lesikar 2001). For each auger hole, depth of topsoil was measured and averaged for each facility.

Root Processing: Each core was weighed, wrapped in cellophane (Kokko et al. 1993), stored at $4^{\circ} \mathrm{C}$ temporarily in a dark fridge, and then processed within $24 \mathrm{hr}$ after extraction (Smit 2000, Lange et al. 2009). Root cores were cut into $8.4 \mathrm{~cm}$ increments with 720 total sections processed. Each increment was gently rinsed with DI water, poured through a $0.5-\mathrm{mm}$ sieve to obtain $>90 \%$ of the roots (Livesley et al. 1999), and padded dry and separated into dark and light roots by eye for better image contrast (Smit 2000). Only roots $\geq 0.3 \mathrm{~mm}$ diameter were used for analysis as this was the minimum value for macropore flow (Jarvis 2007). Non-living roots from topsoil compost were quickly identified and discarded as they were brittle and much darker than live roots.

Root Image Acquisition: A Canoscan 5600F scanner was used with grey scale at $600 \mathrm{dpi}$ (dots per inch). No root staining was performed as background contrast with roots was adequate for analysis in WinRHIZO (Regent Instruments Inc., Quebec, Canada). Scanned area was confirmed by scanning rulers in the $\mathrm{x}$ and $\mathrm{y}$ direction on the scanner. Roots were then dried at $80^{\circ} \mathrm{C}$ for $48 \mathrm{hr}$ (Gregory 2006) using a drying oven (Model I-160B, ELE international, Bedfordshire, UK), each $8.4 \mathrm{~cm}$ depth section weighed (Livesley et al. 1999, Smit 2000), and root mass density (RMD, Table 5) was calculated. The soil volume sections were calculated using the height of each section (8.4 
$\mathrm{cm})$, inner radius of the core $(3.6 \mathrm{~cm})$, and the equation for the volume of a cylinder $\left(\mathrm{V}=\pi \mathrm{r}^{2} \mathrm{~h}\right)$.

Root Image Analysis: Roots were analyzed using WinRHIZO for each $8.4 \mathrm{~cm}$ depth section to determine the following properties: root diameter (RD), root surface area density (RSAD), root volume density (RVD), root length density (RLD), and specific root length (SRL, Table 5). An 8-pixel search window was used (as opposed to a 128pixel) when choosing a grey value threshold for assigning root vs. non-root to individual pixels in the images. This was done as the 8-pixel window tended not to clump root pieces with large numbers of branches and complexity as much as the 128-pixel window. An alternative root image analysis software, RootSnap! (CID Bioscience, Camas, OR), was used to confirm any large or small root values. The same root images were used, each root manually measured by tracing the root from one end to the other end, and then the RootSnap! software computed total root length, area, and volume for that image.

Statistical Analysis: To test precipitation data between time periods, root characteristics at different depths and between time periods ( $\mathrm{J}-\mathrm{F}$ and $\mathrm{M}-\mathrm{J})$, and infiltration rates between time periods the following tests were used. A Shapiro-Wilk normality test was used to determine if root and infiltration data were normally distributed. For normally distributed data, an unequal variance t-test was used (Bartens et al. 2008, Selbig and Balster 2009). For data not normally distributed, the nonparametric Wilcoxon rank sum test was used (Bartens et al. 2008, Selbig and Balster 2009).

Linear regression was used to determine the relationship between root characteristics (independent variable) and infiltration rate (dependent variable). 
Preliminary data (Chapter 1) suggested a large range for root characteristics and infiltration rate so as to capture a larger range of the root-infiltration relationship. Linear regression was also used to determine any relationship between variables controlled for (e.g. distance to groundwater) and infiltration rate metrics (e.g. average infiltration rate). Plots with residual versus fitted values were visually examined to determine if data followed a normal distribution (equal scatter around average residual value). Plots were omitted from analysis if this was not the case. R software (version 3.3.0) was used for all calculations.

\section{Results}

Infiltration Rate Seasonal Change: Infiltration rate difference between Juncus and Carex SBFs was greatest in May 2014 (3.7 cm/hr) and least in Jan 2014 and 2015 (1.3 $\mathrm{cm} / \mathrm{hr}$, Fig. 26). Also, Juncus SBFs showed greater infiltration rate variance during March, April, July, and August 2014 (Fig. 26). Juncus SBFs showed greater infiltration rates during May (Fig. 26) and M-J (Fig. 27). Juncus SBFs also showed greater increase $(\mathrm{J}-\mathrm{F}$ to M-J 2014, p-value $=0.02)$, average $(\mathrm{p}$-value $=0.02)$, and maximum $(\mathrm{p}$-value $=$ 0.03) infiltration rates compared to Carex SBFs (Fig. 27). 


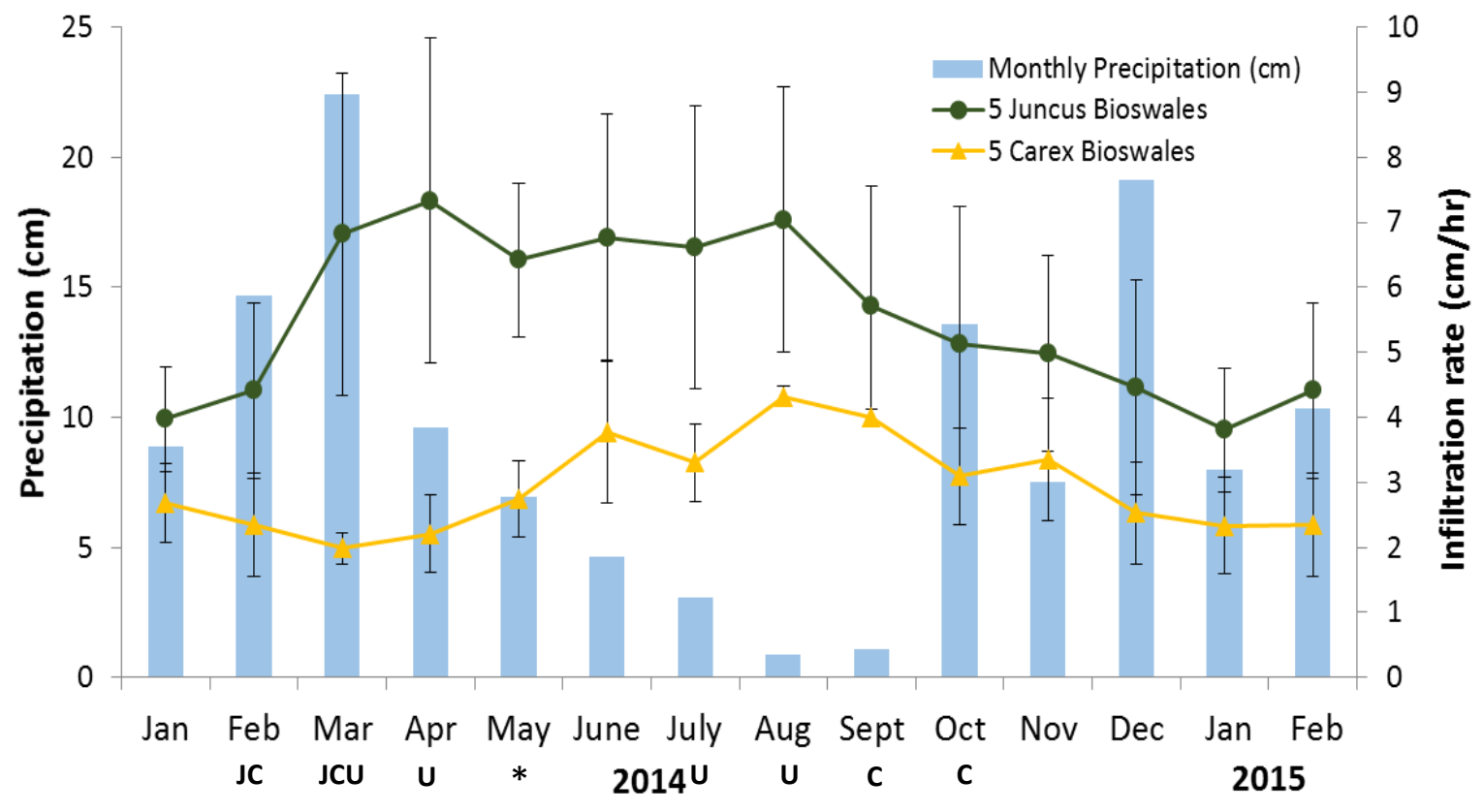

Figure 26: Monthly precipitation (bars), average monthly infiltration rate of Juncus (dark line) and Carex (light line) SBFs, and standard error (error bars). *Significant difference between Juncus and Carex infiltration rate for a given month (p-value $<0.05$, Wilcoxon rank sum test). $U$ indicates unequal variance between Juncus and Carex SBFs for a given month ( $\mathrm{F}$ test for unequal variance, $\mathrm{p}$-value $<0.05$ ). $\mathrm{J}$ and $\mathrm{C}$ indicate significant infiltration difference between one month to the next for Juncus and Carex SBFs, respectively (Wilcoxon rank sum tests, p-value $<0.05$ ). 


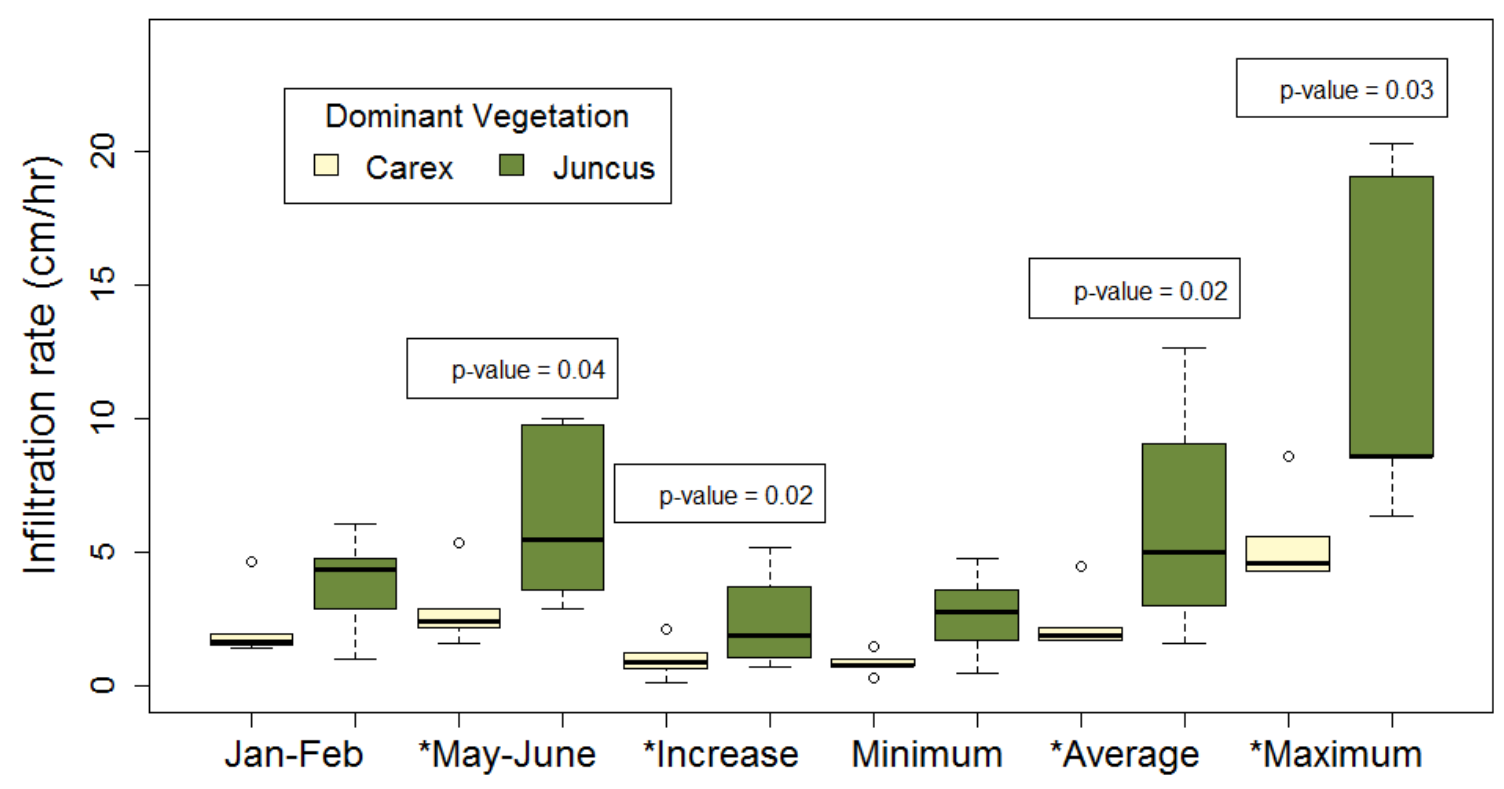

Figure 27: Infiltration rate of five Juncus with Tree(s) and five Carex SBFs during J-F and M-J 2014, and the increase in infiltration rate from J-F to M-J 2014. The minimum (lowest infiltration rate measured), average, and maximum (highest infiltration rate measured) for the five Juncus and five Carex SBFs from Jan 2014 to Feb 2015.

*Significant difference between Juncus and Carex infiltration rates (Wilcoxon rank sum 
Root Mass Density (RMD): RMD was greater for Juncus during J-F 2014 at the 52-93 $\mathrm{cm}$ and subsoil depths, and during M-J 2014 at the 52-59 $\mathrm{cm}$ and subsoil depths compared to Carex SBFs (Tables 6 and 7, Appendix C). RMD in Juncus SBFs showed an increase from J-F to M-J 2014 within the $0-8 \mathrm{~cm}$ and subsoil depths. Whereas Carex SBFs showed no RMD increase during this period. Juncus RMD showed a greater increase (J-F to M-J 2014) within the $69-93 \mathrm{~cm}$ depths and the $1 \mathrm{~m}$ profile and subsoil compared to Carex SBFs (Table 8). This difference in increase was primarily shown within the subsoil primarily at the 69 to $93 \mathrm{~cm}$ depths. Within Juncus SBFs in the $1 \mathrm{~m}$ profile, RMD showed a positive relationship with infiltration rate during M-J 2014 (Figures 28). RMD increase (J-F to M-J 2014) showed a positive relationship with infiltration rate increase within the $1 \mathrm{~m}$ soil profile and topsoil (Fig. 29). Lastly, a positive relationship between the ratio of subsoil root mass density to topsoil root mass density and infiltration rate during M-J 2014 within Juncus bioswales SBFs was shown (Fig. 30). 


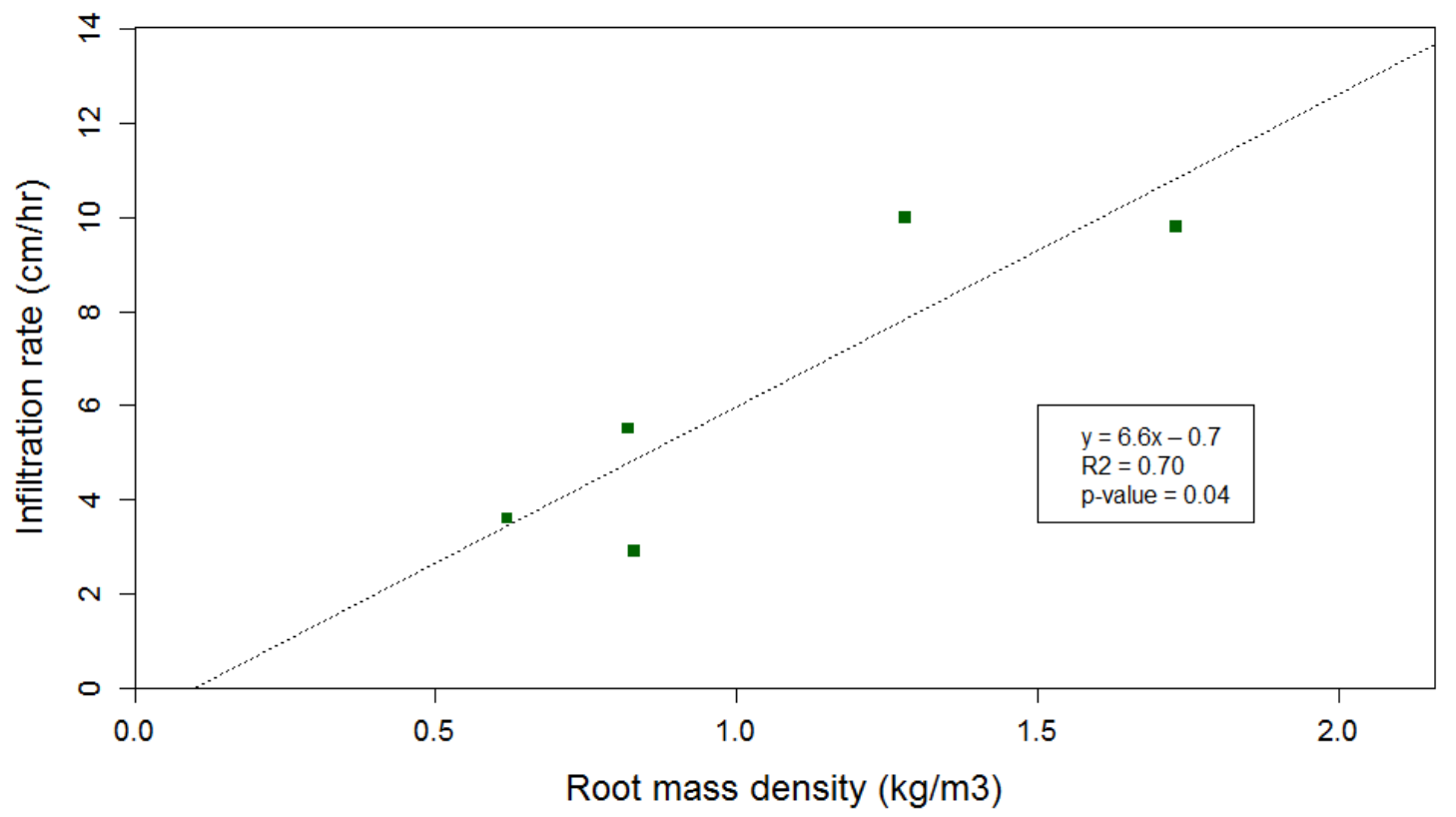

Figure 28: Root mass density (RMD; $1 \mathrm{~m}$ profile) and infiltration rate during M-J 2014 within five Juncus bioswales in Portland, OR.

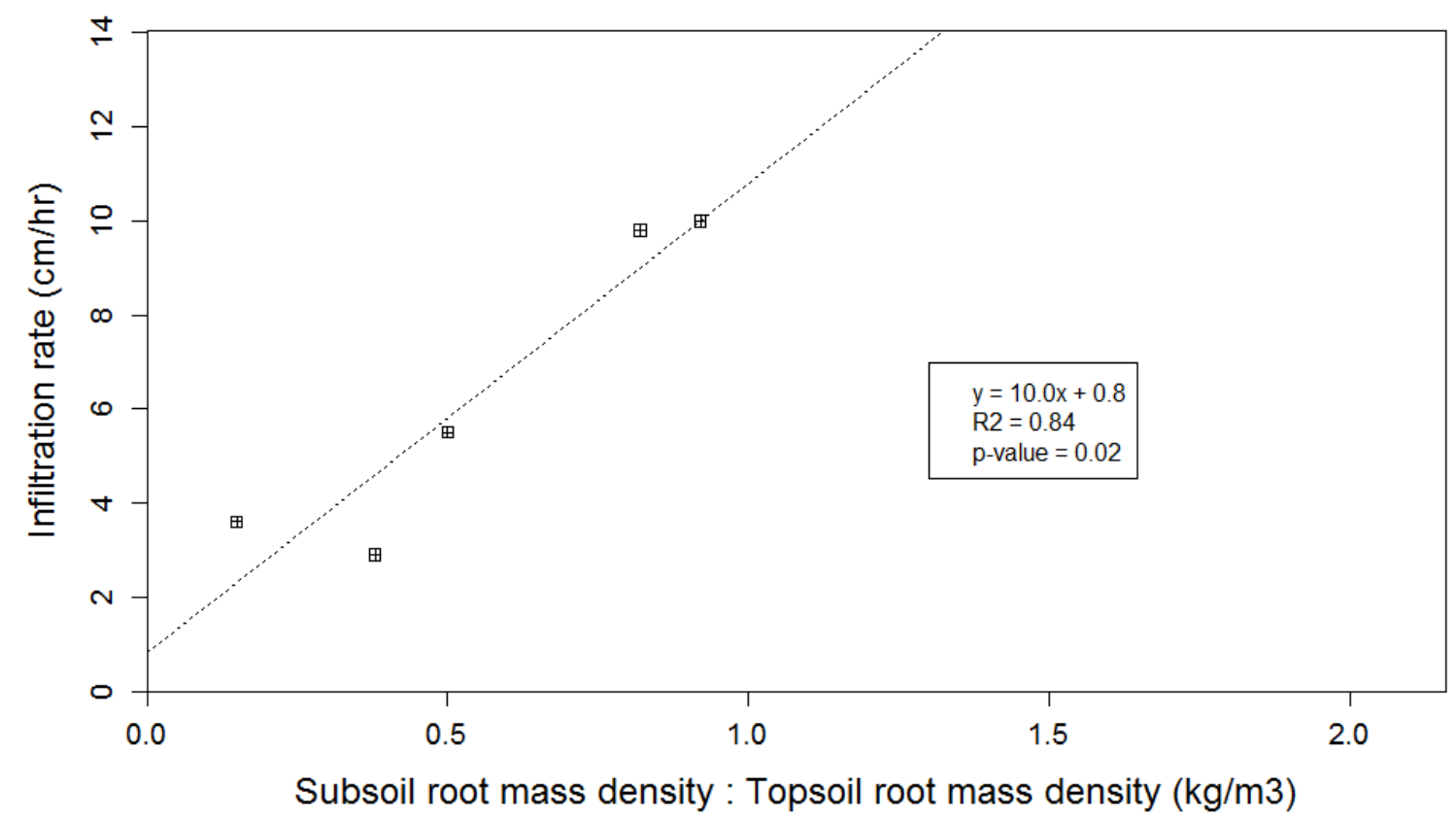

Figure 29: Ratio of subsoil to topsoil root mass density (RMD) and infiltration rate during M-J 2014 within five Juncus bioswales in Portland, OR. 


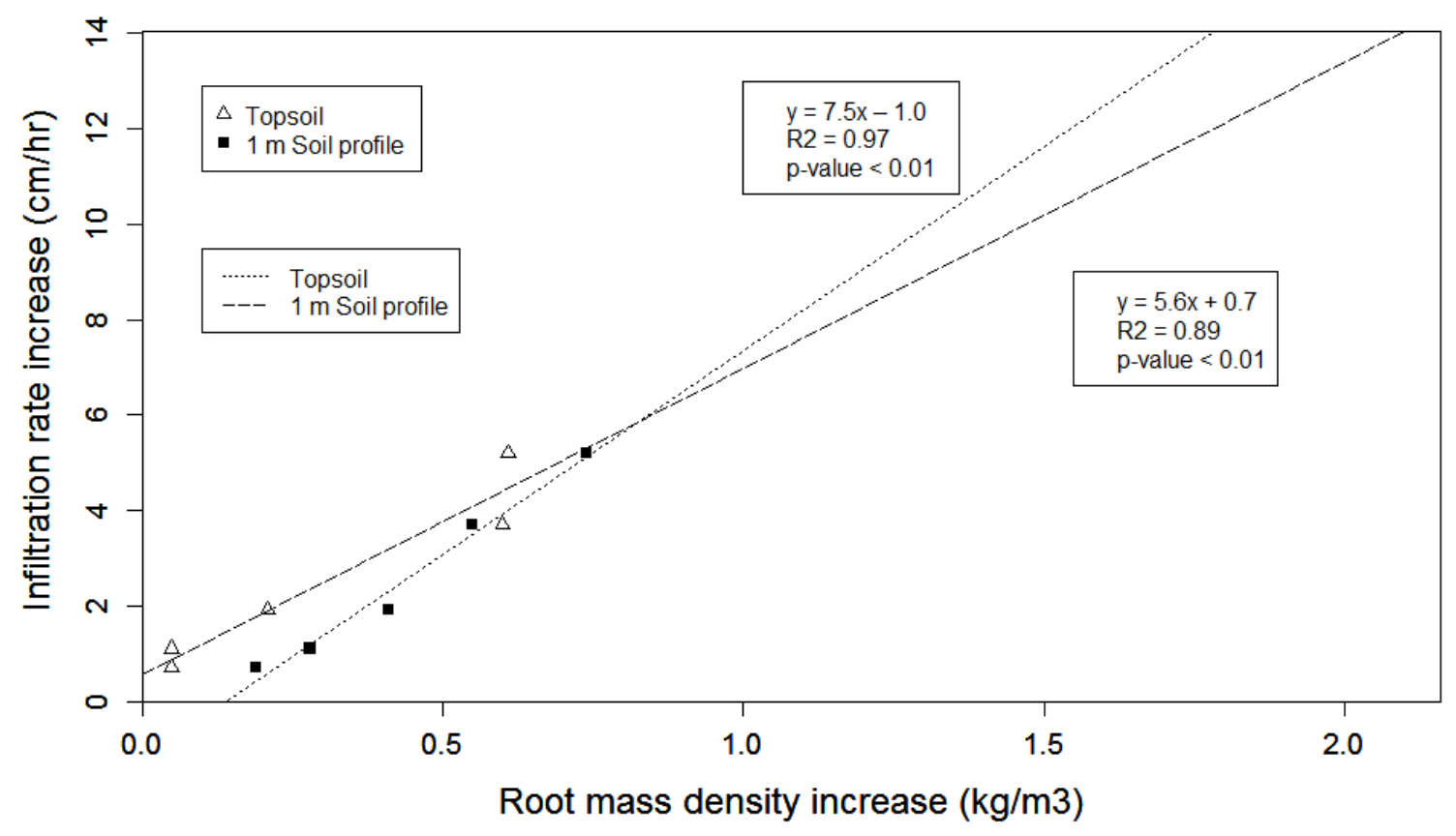

Figure 30: Root mass density (RMD) increase and infiltration rate increase from J-F to M-J 2014 within 5 Juncus bioswales in Portland, OR. 
Table 6: Root characteristic values of Juncus and Carex SBFs during J-F and M-J 2014. Root characteristics include root mass density (RMD), length density (RLD), specific root length (SRL), root surface area density (RSAD), root diameter (RD), and root volume density (RVD). Dashed line indicates average depth of topsoil.

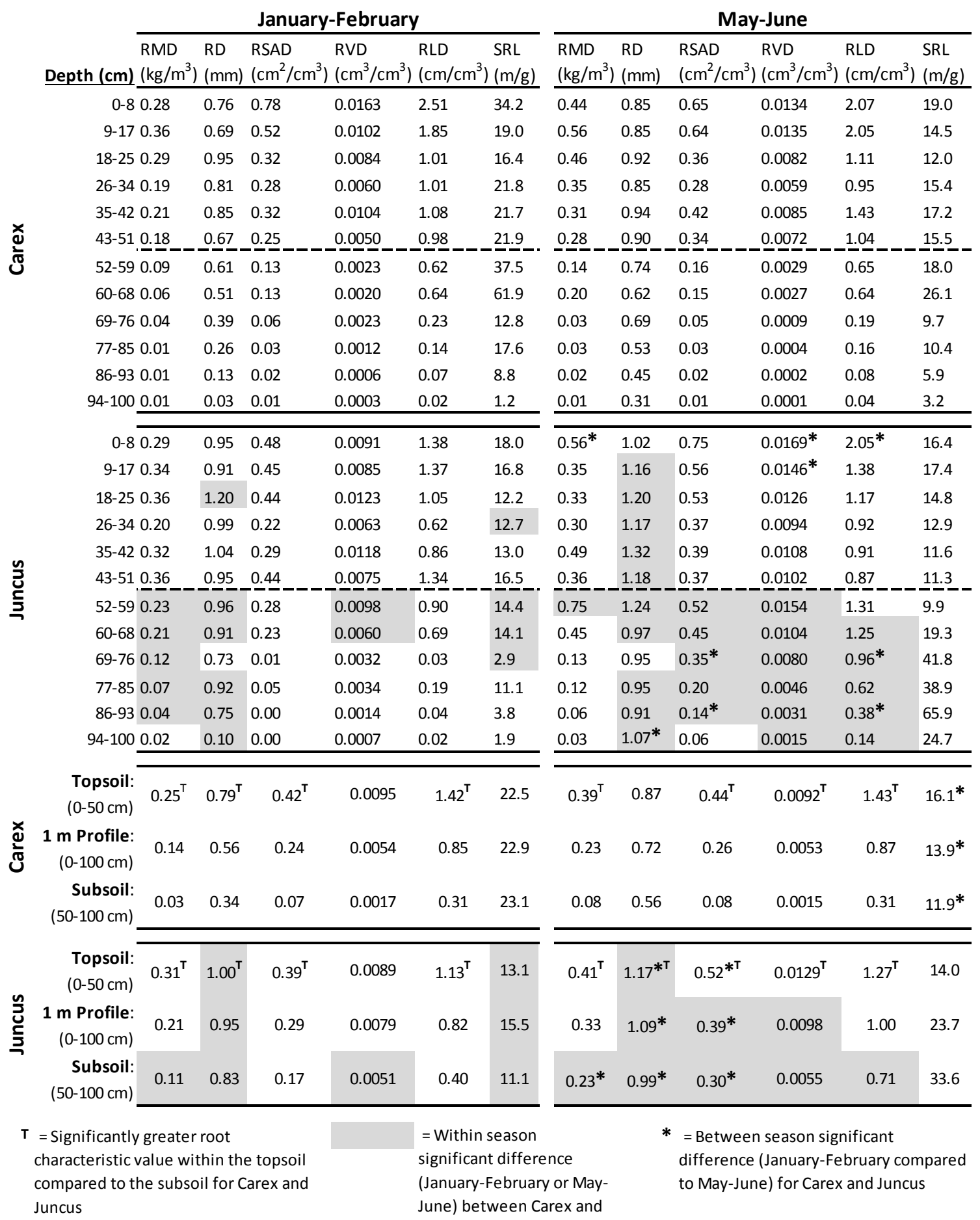


Table 7: Percent difference between Juncus and Carex SBFs among different root characteristics during J-F and M-J 2014. Positive values indicate greater Juncus root characteristics. Root characteristics include root mass density (RMD), length density (RLD), specific root length (SRL), root surface area density (RSAD), root diameter (RD), and root volume density (RVD). Significant difference in root characteristics determined using Wilcoxon rank sum test ( $\mathrm{p}$-value $<0.05$ ). NS indicates no significant difference. Dashed line indicates average depth of topsoil.

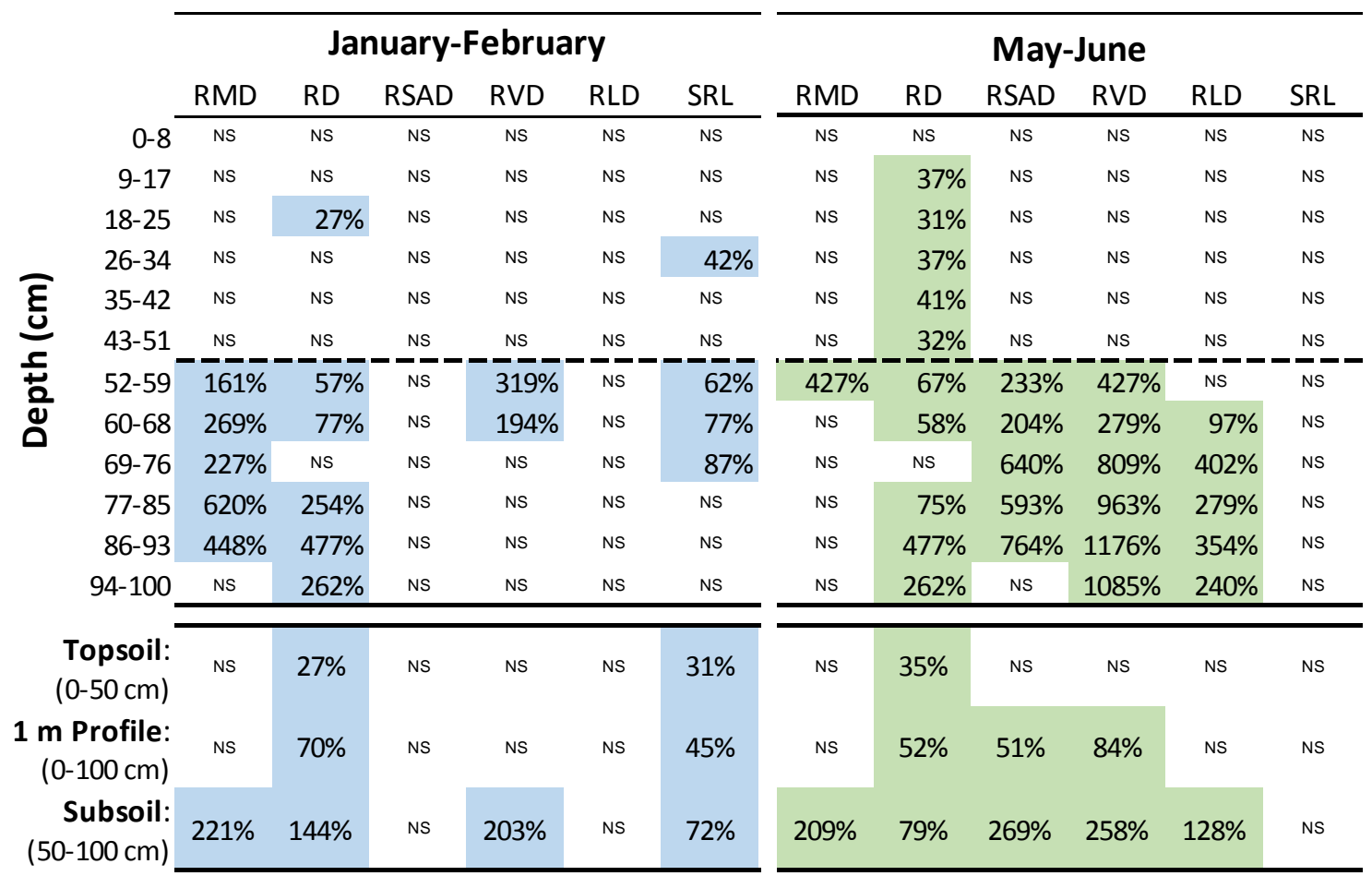


Table 8: Difference between the increase in Juncus and increase in Carex SBFs root characteristics from J-F to M-J 2014. Root characteristics include root mass density (RMD), length density (RLD), specific root length (SRL), root surface area density (RSAD), and root volume density (RVD). Shaded values indicate significant difference (Wilcoxon rank sum test, $\mathrm{p}$-value $<0.05$ ). NS indicates no significant difference. Dashed line indicates average depth of topsoil.

\begin{tabular}{|c|c|c|c|c|c|}
\hline & RMD & RSAD & RVD & RLD & SRL \\
\hline $0-8$ & NS & NS & NS & NS & NS \\
\hline $9-17$ & NS & NS & NS & NS & NS \\
\hline $18-25$ & NS & NS & NS & NS & NS \\
\hline $26-34$ & NS & NS & NS & NS & NS \\
\hline $35-42$ & NS & NS & NS & NS & NS \\
\hline $43-51$ & NS & NS & NS & NS & NS \\
\hline $52-59$ & $-\overline{1 x}$ & $-\overline{N S}$ & $-\overline{N S}$ & $-\overline{N S}$ & $\overline{N S}$ \\
\hline $60-68$ & NS & NS & NS & NS & NS \\
\hline $69-76$ & $2 x$ & $43 x$ & $5 x$ & $28 x$ & NS \\
\hline $77-85$ & $4 x$ & $46 x$ & $5 x$ & $20 x$ & $6 x$ \\
\hline 86-93 & $5 x$ & $192 x$ & $7 x$ & $24 x$ & $23 x$ \\
\hline $94-100$ & NS & NS & NS & NS & NS \\
\hline $\begin{array}{l}\text { Topsoil: } \\
(0-50 \mathrm{~cm})\end{array}$ & NS & NS & NS & NS & NS \\
\hline $\begin{array}{r}1 \text { m Profile: } \\
(0-100 \mathrm{~cm})\end{array}$ & $3 x$ & $6 x$ & NS & $13 x$ & $2 x$ \\
\hline $\begin{array}{r}\text { Subsoil: } \\
(50-100 \mathrm{~cm})\end{array}$ & $2 x$ & $28 x$ & NS & $570 x$ & $4 x$ \\
\hline
\end{tabular}


Root Diameter (RD): Juncus SBFs showed greater RD during J-F 2014 at the 1825, 52-68, and 77-100 cm depths, and within the topsoil, $1 \mathrm{~m}$ profile, and subsoil compared to Carex SBFs (Tables 6 and 7). During M-J 2014, Juncus SBFs showed greater RD compared to Carex SBFs at 9-68 and 77-100 $\mathrm{cm}$ depths, and within the topsoil, $1 \mathrm{~m}$ profile, and subsoil compared to Carex SBFs. RD within Juncus SBFs increased (J-F to M-J 2014) at the 94-100 cm depths, and within the topsoil, $1 \mathrm{~m}$ profile, and subsoil. Similar to RMD, RD showed a greater increase (J-F to M-J 2014) at the 69$93 \mathrm{~cm}$ depths and the $1 \mathrm{~m}$ profile and subsoil compared to Carex SBFs (Table 8). Within Juncus SBFs, a positive relationship between RD within the topsoil and infiltration rate during M-J 2014 was shown (Fig. 31). 


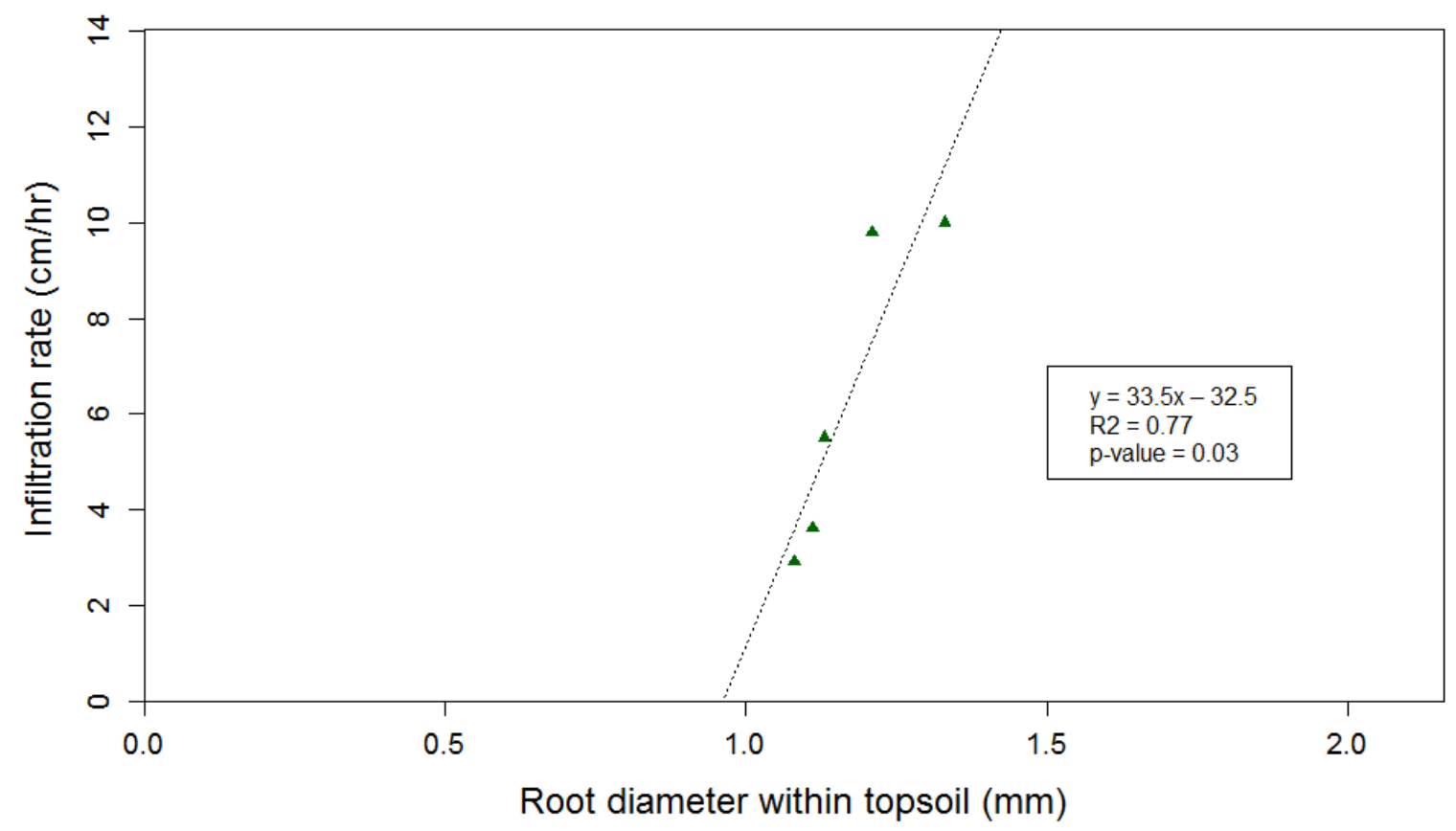

Figure 31: Root diameter (RD) within the topsoil and infiltration rate during M-J 2014 within five Juncus bioswales in Portland, OR.

Root Surface Area Density (RSAD): Juncus SBFs showed greater RSAD compared to Carex SBFs during M-J 2014 at the 52-93 cm depths and within the subsoil, topsoil, and $1 \mathrm{~m}$ profile (Tables 6 and 7). RSAD within Juncus SBFs increased (J-F to M$\mathrm{J}$ 2014) at the 69-76 and 86-93 cm depths, and within the topsoil, $1 \mathrm{~m}$ profile, and subsoil. Also, Juncus showed greater increase (J-F to M-J 2014) in RSAD at the 69-93 $\mathrm{cm}$ depths and within the $1 \mathrm{~m}$ profile and subsoil depths compared to Carex SBFs (Table 8). Within Juncus SBFs, a positive relationship between the ratio of the subsoil RSAD to topsoil RSAD and infiltration rate during M-J 2014 was shown (Fig. 32). For Carex SBFs, a positive relationship between the RSAD within the $1 \mathrm{~m}$ profile and infiltration rate during M-J 2014 was shown (Fig. 32). 


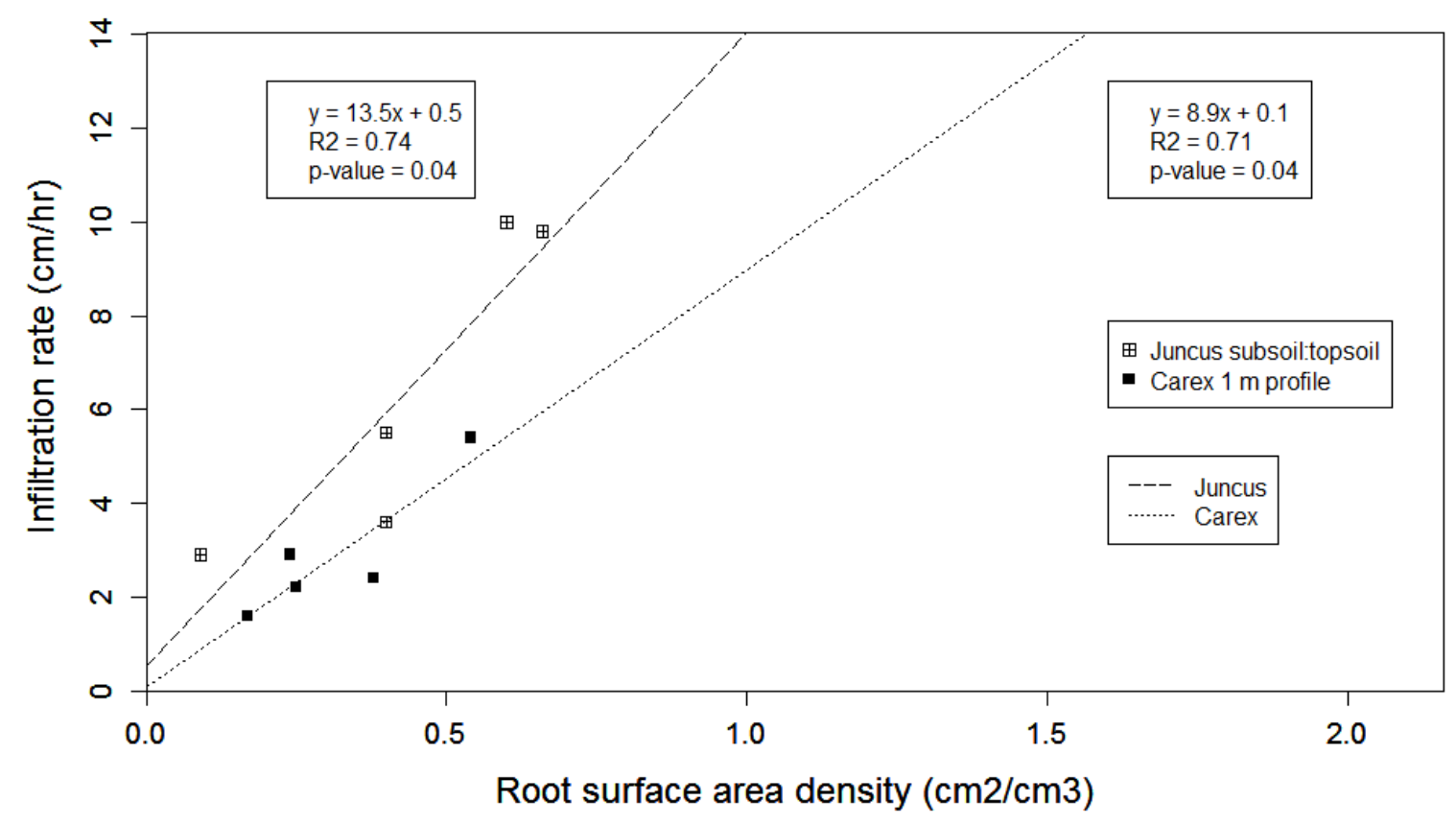

Figure 32: Root surface area density (RSAD) within five Juncus (subsoil: topsoil) and five Carex (1 m profile) SBFs and infiltration rate during M-J 2014 in Portland, OR.

Root Volume Density (RVD): Juncus SBFs showed greater RVD during J-F 2014 at the 52-68 cm depths and within the subsoil compared to Carex SBFs (Tables 6 and 7).

During M-J 2014, Juncus SBFs showed greater RVD compared to Carex SBFs at 52-100 $\mathrm{cm}$ depths and within the $1 \mathrm{~m}$ profile and subsoil compared to Carex SBFs. RVD within Juncus SBFs increased (J-F to M-J 2014) at the 0-17 cm depths. Also, Juncus showed greater increase (J-F to M-J 2014) in RVD at the $69-93 \mathrm{~cm}$ depths compared to Carex SBFs (Table 8). Within Juncus SBFs, a positive relationship between RVD within the topsoil and infiltration rate during M-J 2014 was shown (Fig. 33). 


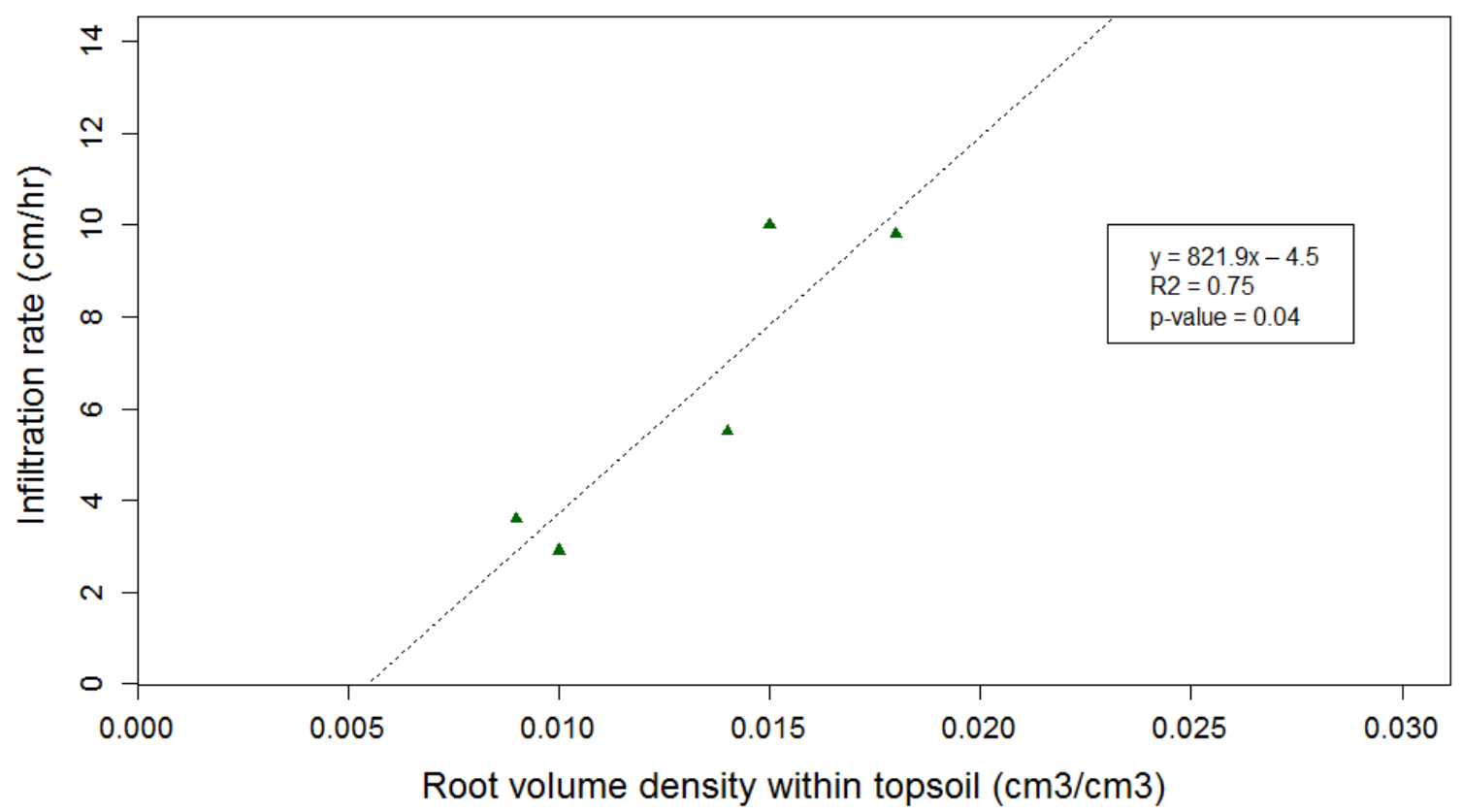

Figure 33: Root volume density (RVD) within the topsoil and infiltration rate during M-J 2014 within five Juncus bioswales in Portland, OR.

Root Length Density (RLD): Juncus SBFs showed greater RLD during M-J 2014 at the 60-100 cm and subsoil depths compared to Carex SBFs (Tables 6 and 7). RLD within Juncus SBFs increased (J-F to M-J 2014) at the 0-8, 69-76, and 86-93 cm depths. Also, Juncus showed greater increase (J-F to M-J 2014) in RLD at the $69-93 \mathrm{~cm}$ depths and within the $1 \mathrm{~m}$ profile and subsoil depths compared to Carex SBFs (Table 8).

Specific Root Length (SRL): During J-F 2014, Juncus SBFs showed lower SRL (thicker roots) compared to Carex SBFs at the 26-34 and 52-76 depths, and within the topsoil, $1 \mathrm{~m}$ profile, and subsoil (Tables 6 and 7). Carex showed a greater increase (from thinner to thicker roots) in SRL from J-F to M-J 2014 at the 77-93 cm depths and in the subsoil and $1 \mathrm{~m}$ profile depths (Table 8). 


\section{Discussion}

Seasonal Infiltration Rate and Root Characteristics: The differences in root growth from J-F to M-J 2014 within Juncus and tree(s) compared to Carex SBFs, likely contributed to the greater infiltration and number of root-infiltration relationships found within Juncus SBFs during M-J 2014. From J-F to M-J 2014 within the $1 \mathrm{~m}$ soil profile, Carex roots generally increased in thickness (lower SRL, root length per root dry mass), while Juncus roots increased most in diameter (RD) and surface area (RSAD). During this time, Carex SBF infiltration was generally lower and less variable than Juncus SBFs, suggesting little change occurred in Carex SBFs for any of the characteristics known to affect infiltration rate. Juncus SBFs showed greater RD and RSAD within the subsoil compared to Carex SBFs than any of the root characteristics during the late spring. During this period, both RD $(33.5 \mathrm{~cm} / \mathrm{hr})$ and RSAD $(13.5 \mathrm{~cm} / \mathrm{hr})$ showed a large change in infiltration per unit increase in root characteristic.

Root Mass Density (RMD): It is likely the greater subsoil RMD within Juncus compared to the Carex SBFs was a result of adaptation strategies (stress-tolerance or stress-avoidance) by both assemblages. Both Carex species (testacea and dolichostachya) are known as drought tolerant and can survive some ponding water. These plants may invest less RMD than the Juncus SBFs within the subsoil during winter to avoid water stress (inundated roots for long periods). Alternatively, these species may retain this low RMD within the late spring to access water that pools at the top of the subsoil to tolerate dryer conditions. Conversely, Juncus may be able tolerate water stress within the subsoil 
more than the Carex species, investing a greater amount of RMD during winter. Then in late spring, Juncus may increase RMD within the subsoil to access water and sustain the larger above ground biomass in comparison to Carex SBFs.

Data suggest it was not just the greater subsoil RMD within Juncus SBFs that provided a relationship with infiltration rate. A relationship between RMD and infiltration rate was found for the $1 \mathrm{~m}$ profile and for the ratio of subsoil to topsoil RMD. This ratio ranged from 0.2-0.9, similar to the ratio (0.5-1.5) Zedler (2007) suggested would be well suited for infiltration. These relationships suggest the greater topsoil RMD also increases infiltration rate, even though no RMD difference between Juncus and Carex SBFs within the topsoil was found during J-F or M-J 2014. Also, the increase (J-F to M-J 2014) in RMD within topsoil and $1 \mathrm{~m}$ soil profile was shown to have a relationship with the increase in infiltration rate. This corresponded with a greater increase in RMD (J-F to M-J 2014) within the $1 \mathrm{~m}$ soil profile for Juncus SBFS compared to Carex SBFs.

Root Diameter $(R D)$ : Results suggest a small difference in $\mathrm{RD}$ can result in a relationship with infiltration rate and proportionally large increase in infiltration rate. Juncus SBFs showed a small but significantly greater average (1.2 vs. $0.9 \mathrm{~mm})$ and range (1.0-1.3 vs. 0.8-0.9 mm) in topsoil RD compared to Carex SBFs during M-J 2014. However, Juncus SBFs showed a strong $\left(\mathrm{R}^{2}=0.72\right)$ relationship with infiltration rate during this period. For the slope of this relationship, just a $0.2 \mathrm{~mm}$ increase from 1.1 to $1.3 \mathrm{~mm}$ in RD resulted in an $8 \mathrm{~cm} / \mathrm{hr}$ increase in infiltration rate from 2 to $10 \mathrm{~cm} / \mathrm{hr}$. 
Root Surface Area Density (RSAD): Data suggest a smaller increase in RSAD within functioning SBFs can result in a greater increase in infiltration rate compared to greenhouse settings (Zhou and Shangguan 2007). Greater RSAD was shown within Juncus compared to Carex SBFs, primarily within the subsoil during M-J 2014. This likely resulted in the positive relationship shown between the ratio of subsoil to topsoil RSAD and infiltration rate within Juncus SBFs during M-J 2014. Even though RSAD was lower within Carex compared to Juncus SBFs, RSAD was the only root characteristic shown in the Carex SBFs to have a relationship with infiltration rate. The Carex $(0.3-0.7 \mathrm{~mm})$ and Juncus $(0.1-0.7 \mathrm{~mm}) \mathrm{RSAD}$ range were lower than the range shown by Zhou and Shangguan $2007\left(1.5-1.7 \mathrm{~cm}^{2} / \mathrm{cm}^{3}, 2.9-4.5 \mathrm{~cm} / \mathrm{hr}, 2007\right)$ to have a strong relationship with infiltration $\left(\mathrm{R}^{2}=0.92\right)$. This study showed a similar infiltration rate range $(1-10 \mathrm{~cm} / \mathrm{hr})$ as Zhou and Shangguan $(2-5 \mathrm{~cm} / \mathrm{hr}, 2007)$. However, both Carex (8.9) and Juncus (13.5) showed greater slopes than Zhou and Shangguan $(1.5,2007)$, suggesting a smaller increase in RSAD within functioning SBFs can result in a greater increase in infiltration rate compared to greenhouse settings.

Root Volume Density (RVD): The steepest slope (greatest RVD increase per unit infiltration rate increase) was shown by RVD out of all root characteristics measured. This could be due to the greater RVD within the $1 \mathrm{~m}$ soil profile within Juncus SBFs compared to Carex SBFs, and possibly the shrinking and swelling of the roots during M-J 2014 (previous chapter). RVD was observed to be greater during M-J but not J-F 2014 within Juncus SBFs compared to Carex SBFs. This difference during M-J 2014 may have contributed to the positive relationship shown. 
Root Length Density (RLD): Greater subsoil RLD within Juncus SBFs is likely an attempt by Juncus vegetation to increase the volume of soil for resource acquisition (Montagnoli 2014), such as for water during the dryer late spring period (Ostonen et al. 2007). Similar to the previous four root characteristics (RMD, RD, RSAD, and RVD), Juncus SBFs showed greater RLD within the subsoil compared to Carex SBFs during MJ 2014. This was primarily the result of a large RLD increase (J-F to M-J 2014) at the 6976 and 86-93 depths within Juncus SBFs.

Specific Root Length (SRL): During J-F 2014 at all depths, results suggest Carex invests less in root growth and attempts to optimize resource extraction using thinner roots (higher SRL, Montagnoli 2014) compared to Juncus. Conversely, during M-J 2014 no SRL difference between Carex and Juncus SBFs was shown. This was likely due to the increase in SRL within Carex SBFs for all depths from J-F to M-J 2014. Long and thin roots (high SRL) are believed to require less reproductive cost compared to short and thick roots (low SRL, Withington et al. 2006). To minimize water inundation damage (i.e. low oxygen) during the winter, Carex vegetation may create long and thin roots (high SRL).

Juncus patens versus tree root effect on infiltration: It is likely that the infiltration rate difference between Juncus and Carex was due primarily to Juncus patens roots, particularly within the topsoil, with tree roots contributing to infiltration rate as well. Preliminary work showed most J. patens roots within the topsoil, most of the topsoil contained more $J$. patens than tree roots, most tree roots were at least $30 \mathrm{~cm}$ away from $J$. patens individuals (Olney et al. 2010), and the majority of the J. patens roots examined 
were greater than $0.3 \mathrm{~mm}$ in diameter (Jarvis 2007). Trees in this work demonstrated healthy growth compared to similar studies (MacDonagh 2015), are well adapted for the SBF environment (Scharenbroch et al. 2016), are playing several rolls in stormwater management (Breen et al. 2004), and are enhancing SBF infiltration. However, several factors suggest they are not contributing as much as J. patens, particularly within the topsoil (above), including no relationship between above ground tree characteristics and infiltration rate shown, small size $(6.3 \mathrm{~cm}$ average $\mathrm{DBH}, 5-10$ year old trees, MacDonagh 2015), and short ponding time ( $<48$ hours) not allowing for much transpiration.

Conclusions: This work strongly suggests plant roots with greater biomass can increase infiltration in stormwater bioretention facilities (SBFs) greater than plants with lower root biomass. Specifically, four Juncus and tree(s) root characteristics (RMD, RSAD, RD, and RVD) showed greater values within the subsoil compared to Carex SBFs and a positive relationship with infiltration rate during M-J 2014. Within Juncus SBFs, the slope (unit increase in infiltration rate for every unit increase in the root characteristic) for most of these root characteristics was greater than the slope found within Carex SBFs.

In contrast, the low root characteristic values and the lack of root growth (J-F to M-J 2014) within the Carex SBFs may explain the limited evidence showing root characteristics increasing infiltration rate. Carex SBFs showed an infiltration rate decrease from Feb to Mar and no increase from J-F to M-J 2014. Only one root characteristic (topsoil RSAD) within the Carex SBFs showed a relationship with infiltration rate during M-J 2014. 
This work showed some root characteristics may increase infiltration rate to a greater extent at different depths compared to other root characteristics. RMD and RSAD were shown to increase infiltration rate for the entire $1 \mathrm{~m}$ soil profile (topsoil surface to subsoil), while RD and RVD were shown to increase infiltration rate more within the topsoil. RD and RVD both showed a small increase would result in a large increase in infiltration rate (slope). 


\section{Chapter 4}

\section{Management Implications and Summary}

\section{Mechanism for Root-Enhanced Infiltration}

Root adaptation to the SBF environment likely resulted in greater infiltration rates. It is likely the moderate bulk density and amount of clay within the subsoil was low enough to allow for healthy root growth (Bowen 1981) but high enough to retain soil moisture for use by plants in late spring (Bartens et al. 2009). The increase in RMD, RD, RSAD, and RVD along the entire $1 \mathrm{~m}$ soil profile from J-F to M-J 2014 likely enlarged the rhizosphere volume. Specifically, the subsoil RMD and RD increase (J-F to M-J 2014) may have been an adaptation to the higher bulk density and percent fines (Gregory 2006). Auxin and gibberellins likely stimulated root growth (Gregory 2006) including more dense components, such as the Casparian strip, increasing RMD (Gregory 2006). This likely provided greater structural integrity and resistance against soil compaction (Ghestem 2011). Ethylene, and the resulting radial turgor pressure immediately behind the root tips, likely increased RD (Materechera et al. 1991, Clark et al. 2003).

The above process was likely at its peak during late spring, and combined with smaller and shorter rain events, longer and warmer dry periods, and root and soil swelling and shrinking, resulted in greater rhizopore volume (space between root and soil) and 
thus greater infiltration rates. From winter to late spring, a relationship was shown between the increase in root characteristics and the increase in infiltration rate. It is likely the longer dry periods and higher temperatures during late spring resulted in greater evapotranspiration within the SBFs. This may have caused the shrinking of roots (up to 60\%, Huck et al. 1970), clay loam subsoil (moderate), and sandy loam topsoil (low), enlarging the rhizopore. The low percent of clay within the topsoil (14\%) and moderate percent clay within the subsoil (26\%) may have been low enough to not impede root growth (Daddow and Warrington 1983), but high enough to provide soil shrinking during late spring dry periods (Peng and Horn 2013). The rhizopore volume would have been greatest at the end of a dry period and right before the next rain event. As the average late spring root diameter was $1.1 \mathrm{~mm}$ in this study, root diameter can be thinner than the rhizopore diameter (Ghestem et al. 2011), the minimum diameter for macropore flow is $0.3 \mathrm{~mm}$ (Jarvis 2007), and root diameter can decrease up to 60\% within a diurnal period (Huck et al. 1970), it is likely that roots within this study enhanced SBF infiltration.

\section{Potential for Root-enhanced Infiltration within SBFs}

Several factors should be considered when determining the potential for roots to increase infiltration rate within SBFs (Appendices A and B, Table 9). Not all of the following recommendations are necessary and by no means are these recommendations an exhaustive list of all the approaches for estimating the contribution roots may have to infiltration rate within an SBF. 
First, all safety precautions should be considered, especially if any digging will be conducted, such as for sampling subsoil bulk density. Utility lines, such as water pipes, locations should be flagged by contacting the local utility location service (UNC 2013) prior to any site visits. Keep in mind utility lines may run through SBFs at shallow depths. During the initial site visit determine any utility locations and ascertain any traffic safety issues, such as SBF along highways.

Second, any pre-existing/external to the facility site characteristics should be compared with characteristics found in this work (Appendix A and B). As mentioned in Chapter 1 introduction, several environmental characteristics can impede root growth. These include soil characteristics and water table maps from the USGS, and hydraulic conductivity measurements from double-ring infiltrometers. As well, the health of vegetation adjacent to SBFs should be considered as these plants can be a general indicator of environmental health. Also, data from this and other (Selbig and Balster 2009) work suggest allowing at least 3 years of healthy root growth into the subsoil for roots to enhance infiltration. Also, several environmental characteristics such as seasonal precipitation, evapotranspiration, and soil characteristics should be considered.

Third, the facility specifications, such as facility size, should be considered with respect to how they may affect site characteristics. For example, large facility area with small catchment area can provide insufficient water for trees within SBFs. Commonly site plans are available from the government agency with jurisdiction of the facility of interest. These typically provide measurements of the facility, presence of bottom liners, plant selection, and other important information. One of the more important 
considerations is selecting a facility to catchment size appropriate for the precipitation regime and subsoil infiltration rate. For example, larger SBF to catchment size is more appropriate for short, large intensity rainfall especially if the subsoil has low to moderate hydraulic conductivity. Also, less than 2 days of ponding is typically recommended for healthy root growth (Bartens et al. 2009). Nearby rain gage data, subsoil hydraulic conductivity, and site measurements can be used within a simplified model, such as HydroCAD, to estimate ponding time and thus effect on plant roots. In addition, a $0.5 \mathrm{~m}$ depth of topsoil used in Portland SBFs is recommended as this work showed root characteristics within the topsoil increase infiltration rate.

If trees are being considered, facility and site characteristics effect on tree health, and thus root-enhanced infiltration, should be considered. Available root volume and soil quality commonly have a large effect on tree growth. A $2 \mathrm{~m}^{3}$ of soil volume per $1 \mathrm{~m}^{2}$ of crown projection is recommended (MacDonagh 2011). Also, soils with higher percent loam tend to have more extensive and larger root growth (MacDonagh 2015). In addition, the majority of the tree canopy should not be shaded by any buildings so as to maximize photosynthesis and tree growth.

Finally, root characteristics of the facility of interest can be compared to values found in this (Table 9) and other work (Nassif and Wilson 1975, Day et al. 2000, Bharati et al. 2002, Devitt and Smith 2002, Zhou and Shangguan 2007 and 2008, Bratieres et al. 2008, Bartens et al. 2008, Lange et al. 2009). As root characteristic values shown in this work mostly overlapped with values shown in similar studies, managers can use these values (Table 9) as lower thresholds at which point roots may be enhancing infiltration at 
their site. I recommend investing in simple and inexpensive equipment to complement a root/soil coring device as it will save time, reduce injury, and improve sample quality during extracted. These include a ratchet for ease of coring, an assortment of cleaning tools to avoid device jamming, and sharpening tools for the core teeth if numerous samples are planned. I also recommend setting up an assembly line and using several technicians for root core processing and analysis as this is a time-intensive endeavor. I recommend first determining RMD as this characteristic is easy to determine, widely used/compared, and has been shown to have a positive relationship with hydraulic conductivity (Bartens et al. 2008). It is likely that roots will contribute more to infiltration rate over time within SBFs with healthy vegetation growth over several decades, especially with trees. Much work has shown how mature trees enhance SBF performance much more than smaller trees (Breen et al. 2004, MacDonagh, P. 2015, Scharenbroch et al. 2016). 
Table 9: Root characteristic ranges for significant relationships (linear regression) found between Juncus or Carex (shaded) SBFs and infiltration rate during M-J 2014. Root characteristics include root mass density (RMD), length density (RLD), specific root length (SRL), root surface area density (RSAD), root diameter (RD), and root volume density (RVD).

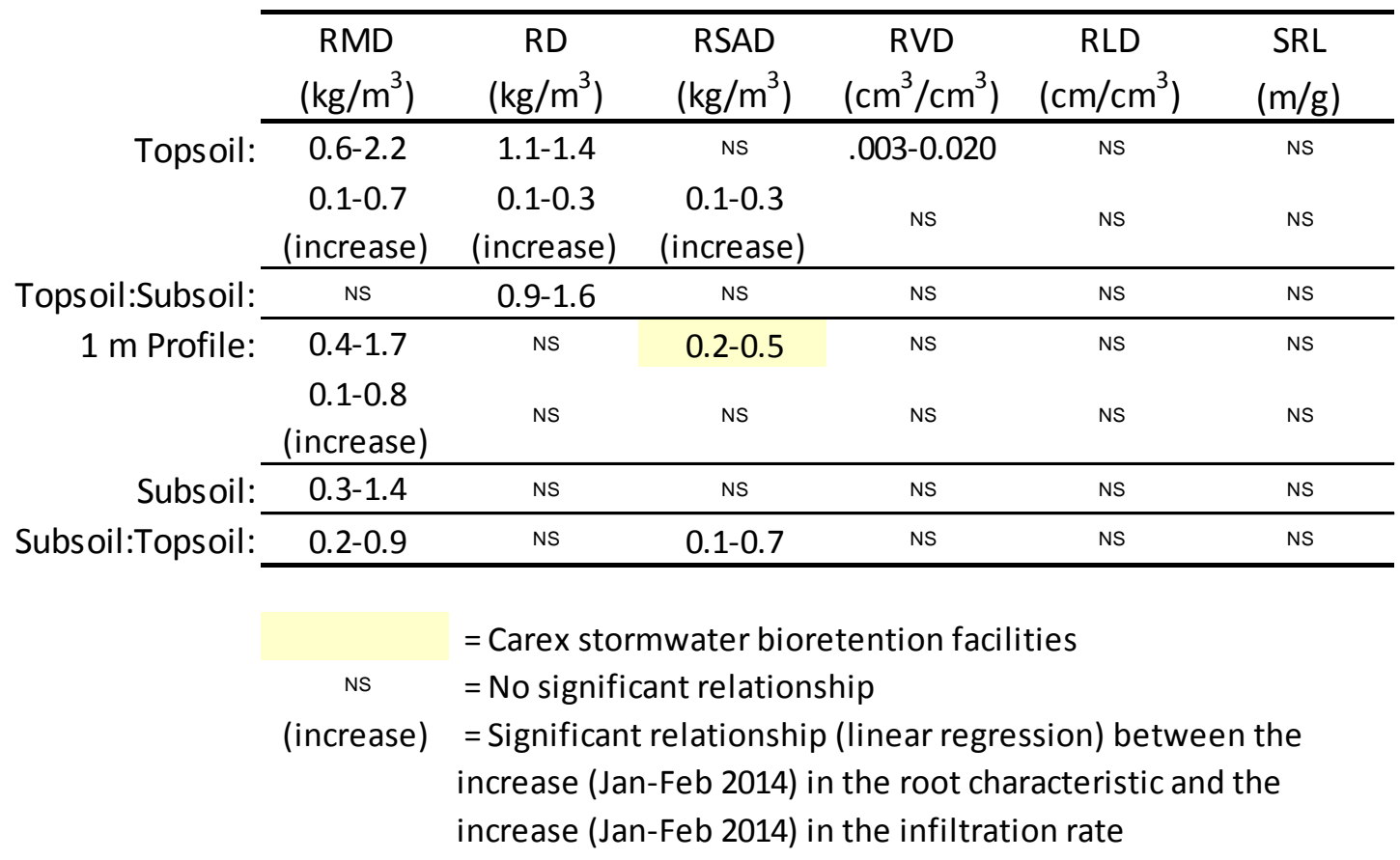

\section{Selection and Installation of Vegetation for Root-enhanced Infiltration within SBFs}

Plant choice (Appendix A and B) should be considered when determining the potential for roots to increase infiltration rate within SBFs. My findings suggest different plant assemblages possess different root characteristics at different depths which have a positive relationship with infiltration rate within SBFs.

First, compile a list of available/potential plants with the following recommendations: select wetland plant species native to your area (Lichvar et al. 2016), select species known to withstand more extreme environmental conditions found in SBFs 
(e.g. dry, hot, long summers, several days of water inundation, frozen topsoil, foot traffic), consider other performance measures important to your application such as aesthetics, and select species of low to moderate cost and moderate to high availability from local nurseries to optimize number of plants per facility.

Second, from this list, determine if any literature on root characteristics exists for each species. Keep in mind that several factors can alter root characteristics even within the same landscape (Gregory 2006). If literature does exist, compare root characteristics and depths with those found here to have a relationship with infiltration (Table 9). Also, determine if plant species have similar seasonal growth found in this work (Tables 2, 3, 5, 6 , and 7). I recommend selecting wetland plant species that show a large increase in root biomass in spring/early summer, as results here and elsewhere (Selbig and Balster 2009) show this has a relationship with infiltration. Similarly, I recommend selecting wetland plant species that show a large change in in shrinking and swelling of root characteristics.

Third, the following installation procedures are recommended: do not install small size plants as the time for plants to penetrate within the subsoil will be greatly increased, install plants close together (e.g. 1-2 ft on center) to maximize root density, water plants regularly during the first 2-3 dry periods/years, and install plants right after the period of greatest plant stress, such as early fall for plants known to experience moderate water stress during dry periods.

Finally, long-term environmental factors should be considered. Plants will require several years to develop root growth. Environmental conditions will change in many areas over time and thus alter the stressors on vegetation (USDA 2016). For example, 
large/mature trees are often desired to maximize transpiration in the summer, cooling the surrounding environment, and reducing runoff (Scharenbroch et al. 2016). However, larger trees may reduce the soil moisture within SBFs, and longer, hotter, dryer summers are occurring more frequently (Mote and Salathe Jr. 2010). These conditions can result in greater SBF vegetation die off (Denis O'Brien personal communication).

\section{Effect of Larger-root Versus Smaller-root Vegetation on Time to Infiltrate a Large Storm}

Approximately 18 hours less time is required to infiltrate a $2.9 \mathrm{~cm}$ storm for five Juncus (12.2 hr) compared to five Carex (30 hr) SBFs, using data from this work and several assumptions. Over a $30 \mathrm{hr}$ period from May $18-19^{\text {th }}$ approximately $2.9 \mathrm{~cm}$ of precipitation fell (Fig. 34). Average infiltration rate during this time was $6.0 \mathrm{~cm} / \mathrm{hr}$ for five Juncus SBFs and $2.4 \mathrm{~cm} / \mathrm{hr}$ for five Carex SBFs (Fig. 34). The total catchment area was $449 \mathrm{~m}^{2}$ for Juncus and $502 \mathrm{~m}^{2}$ for Carex SBFs (Appendix B). The total stormwater inflow into the SBFs was $13.1 \mathrm{~m}^{3}$ for Juncus and $14.7 \mathrm{~m}^{3}$ for Carex. SBF area for both Juncus and Carex totaled approximately $81 \mathrm{~m}^{2}$ for each group of five SBFs. To simplify

the following was assumed: no overflow out of SBFs, ponding depth always greater than zero for all SBFs until storm completely infiltrated (no ponding), steady infiltration rate within all SBFs, and runoff coefficient of $90 \%$. After all of the $2.9 \mathrm{~cm}$ storm is infiltrated into the Juncus SBFs, $7.0 \mathrm{~m}^{3}$ still remains in the Carex SBFs (above the topsoil surface) to infiltrate. This scaled-up, simplified calculation of several SBFs demonstrates the performance increase larger-root plants can provide. 


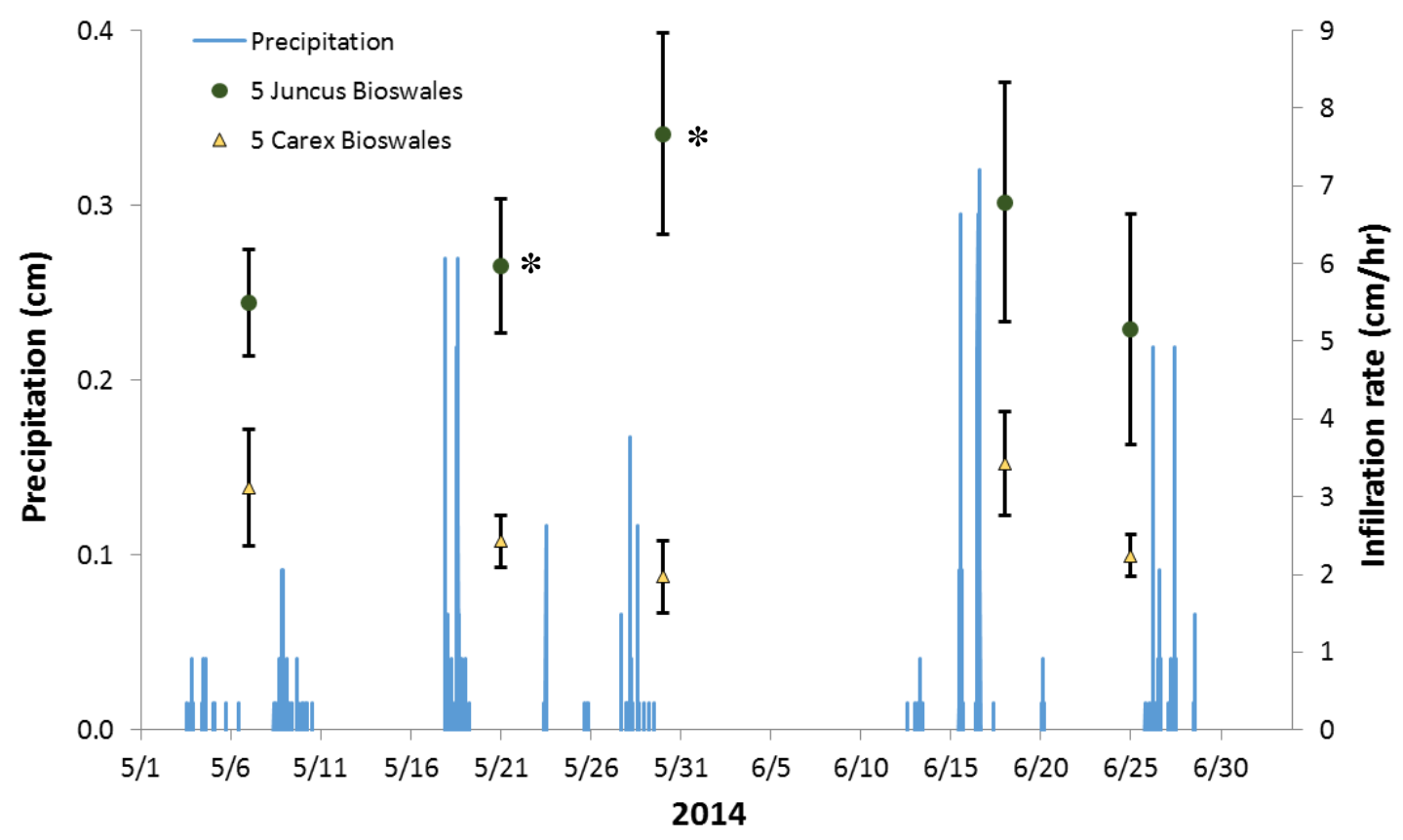

Figure 34: M-J 2014 precipitation every 5 minutes (bars) and average weekly infiltration rates for five Juncus (circles) and five Carex (triangles) bioswales with standard error of weekly infiltration rates (error bars). *Significantly greater infiltration rate within Juncus compared to Carex bioswales.

\section{SBFs With and Without Vegetation}

This work adds to the growing number of studies showing how the presence of vegetation increases stormwater bioretention facility (SBF) performance (Breen et al. 2004, Le Coustumer et al. 2012, Greene 2008, Bartens et al. 2008 and 2009, Hatt et al. 2009, Selbig and Balster. 2009, Read et al. 2008 and 2010, MacDonagh 2011 and 2015, 
Scharenbroch et al. 2016). These studies primarily include how SBF vegetation can increase hydraulic conductivity, infiltration, and pollutant capture. However, some studies show vegetation not enhancing SBF performance. Spromberg et al. (2016) found no difference in the ability of SBF soil with and without vegetation to lower adult Coho mortality when stormwater was filtered through SBF soil and exposed to the adult Coho.

The growing number of studies documenting how vegetation increases SBF performance supports the belief that the performance benefit from plants outweighs the associated costs of plant installation and maintenance. Generally, SBF construction cost per area is similar over clay subsoil and lower over sandy loam subsoil compared to other stormwater control measures (SCM), such as sand filters and stormwater wetlands (Wossink and Hunt 2004). Typically plants represent a small percent of the construction costs (personal communication Tim Kurtz, 2016). SBF maintenance cost per catchment area treated is generally lower than most other SCMs, and the capture of most pollutants is similar to other SCMs (Wossink and Hunt 2004). However, the associated maintenance cost of vegetation (i.e. dead plant removal) is likely the largest component to SBF maintenance (Wossink and Hunt 2003 and 2004). Future research should determine the portion of the maintenance cost attributed to vegetation and monetize the contribution plants provide to the performance of SBFs (Foster et al. 2011). 


\section{Summary}

The primary focus of this work was to determine if any evidence exists of rootenhanced infiltration within SBFs and whether a plant assemblage with greater root biomass shows greater infiltration compared to plant assemblage with lower root biomass. The increase in flooding and water quality degradation in urban areas has led to the widespread use of SBFs, including in the study location, Portland, OR. The two primary functions of SBFs, lowering peak flow and retaining pollutants (Hunt et al. 2012), are both improved with increased infiltration within the SBF. Demonstration of root-enhanced infiltration in many settings suggested this process may be taking place in fully functioning SBFs. The widespread use of vegetation in the numerous SBFs within SE Portland enabled the comparison of similar SBFs for root-enhanced infiltration.

Chapter 2: This first study demonstrated root characteristics at different depths had a positive relationship with infiltration, primarily in the late spring. The scope of this work included SBFs within SE Portland with a large range in SBF root biomass. Many variables within and surrounding the tested SBFs were held as constant as possible to discern presence and strength of the relationship between root characteristics and infiltration rate. While most root characteristics showed large growth in the subsoil during late spring, the positive relationships found between root characteristics and infiltration rate were within the topsoil, subsoil, and in the full 1-m profile. In addition, an increase in three root characteristics and an increase in infiltration rate were shown. These results also show how specific root characteristics may increase infiltration at different depths. 
Chapter 3: This second study demonstrated how SBFs planted with larger-root biomass vegetation can result in greater infiltration rates compared to SBFs planted with smaller-root biomass vegetation. Factors known to affect root growth and infiltration were held as constant as possible among the smaller and larger root SBFs. The larger-root vegetation showed more root characteristic relationships with infiltration rate than the smaller-root vegetation. Although, the smaller-root vegetation did show a relationship between RSAD and infiltration rate within the $1 \mathrm{~m}$ profile. Even though the majority of the root characteristics were smaller for this smaller-root vegetation, RSAD was within a similar range as the larger-root vegetation and did provide root-enhanced infiltration.

Plant Roots Increase SBF Infiltration: This work clearly demonstrated that plant roots increase SBF infiltration in late spring. Two of the root characteristics shown to have a strong relationship with infiltration rate have also been shown to have a strong relationship with hydraulic conductivity (RMD, Bartens et al. 2008) and infiltration rate (RMD, Lange et al. 2009, RSAD, Zhou and Shangguan 2007). Also, many environmental characteristics known to greatly effect infiltration showed no relationship. These included soil bulk density (Massman and Butchart 2001), precipitation event size (Nassif and Wilson 1975), and SBF sizing (Standers et al. 2010, Hunt et al. 2012). The only characteristic controlled for that showed a slight relationship with infiltration rate was soil percent fines (silt and clay, Saxton and Rawls 2006).

Management Implications: Several areas of vegetation management in SBFs were discussed. For determining root-enhanced infiltration I recommended the following: exercise safety, consider many facility site characteristics, review facility specifications, 
and compare root characteristics to values found in this and other work. When considering plant species to increase infiltration rate, I recommended the following: compile a list of available plants, refer to literature on root characteristics, install plants to maximize root biomass, and continue to discuss plant species selection. Using data from this work and several assumptions, I calculated approximately 18 hours less time is required to infiltrate a $2.9 \mathrm{~cm}$ storm for five Juncus (12.2 hr) compared to five Carex (30 hr) SBFs. Finally, the growing number of studies, including those described in this dissertation, showing how vegetation increases SBF performance supports the management strategy that the performance benefit from plants in bioswales strongly outweighs the associated costs of plant installation and maintenance. 


\section{References}

Archer, N. A. L., Quinton, J. N., and T. M. Hess. 2002. Below-ground relationships of soil texture, roots and hydraulic conductivity in two-phase mosaic vegetation in South-east Spain. Journal of Arid Environments 52:535-553.

Atwell, B. J. 1990. The effect of soil compaction on wheat during early tillering. I Growth, development and root structure. New Phytologist. 115:29-35.

Bagarello, V., Iovino M., and J. Lai. 2016. Testing steady-state analysis of single-ring and square pressure infiltrometer data. Geoderma 261:101-109.

Barnes, K. B., Morgan, J. M. III, and M. C. Roberge. 2002. Impervious surfaces and the quality of natural and built environments. Department of Geography and Environmental Planning, Towson University, Baltimore, Maryland.

Bartens, J., Day, S. D., Harris, J. R., Dove, J. E., and T. M. Wynn. 2008. Can urban tree roots improve infiltration through compacted subsoils for storm water treatment? J. Environ. Qual. 37:2048-2057.

Bartens, J., Day, S. D., Harris, J. R., Wynn, T. M., and J. E. Dove. 2009. Transpiration and root development of urban trees in structural soil stormwater reservoirs. Environmental Management. 44:646-657.

Bell, D. L. and Sultan, S. E. 1999. Dynamic phenotypic plasticity of root growth in Polygonum: a comparative study. Am. J. Bo. 86:807-819.

Bernard, J. M. 1974. Seasonal changes in standing crop and primary production in a sedge wetland and an adjacent dry old-field in central Minnesota. Ecology $55: 350-359$

BES, 2014. When it goes to the ground. City of Portland Bureau of Environmental Service (BES) Stormwater Solutions Handbook. (Accessed May 2016)

Bharati, L., Lee, K. H., Isenhart, T. M. and R. C. Schultz. 2002. Soil-water infiltration under crops, pasture, and established riparian buffer in Midwestern USA. Agroforestry Systems, 56:249-257.

Black, K. E., Harbron, C. G., Franklin, M., Atkinson, D., and J. E. Hooker. 1998. Differences in root longevity of some tree species. Tree Physiology, 18:259-264.

Bohren, K., Hart, T. D., Stevens, H., and T. Kurts. 2012. Topsoil and subsoil characteristics within in bioswales in Portland, Oregon. City of Portland Bureau of Environmental Services. 
Bowen, H. D., 1981. Alleviating mechanical impedance. In: Modifying the root environment to reduce crop stress. G.E Arkin and H.M. Taylor (Editors), ASAE, Michigan, pp. 21- 53.

Bratieres, K., Fletcher, T. D., Deletic, A., and Y. Zinger. 2008. Nutrient and sediment removal by stormwater biofilters: A large-scale design optimization study. Water Research, 42:3930-3940.

Breen, P., L. Denman, P. May, and S. Leinster. 2004. Street trees as stormwater treatment measures. In: WSUD 2004: Cities as catchments. International Conference on Water Sensitive Urban Design, Proceedings of. Engineers Australia, Barton, Australia. p. 701.

Brown, R. A., and W. F. Hunt. 2010. Impacts of construction activity on bioretention performance. Hydrologic Engineering, Vol. 15, No. 6:386-394.

Burton, G. A. J., and Pitt, R. E. 2002. Stormwater effects handbook: a toolbox for watershed managers, scientists, and engineers. 1 edition, CRC Press, USA.

Carrier, W. D. 2003. Goodbye, Hazen; Hello, Kozeny-Carman. J. Geotech. Geoenviron. Eng., 129(11):1054-1056.

Chaiwanon, J., and Z. Wang. 2015. Spatiotemporal Brassinosteroid signaling and antagonism with Auxin pattern stem cell dynamics in Arabidopsis roots. Current Biology 25:1031-1042.

Clapp, R. B. and G. M. Hornberger. 1978. Empirical equations for some soil hydraulic properties. Water Resources Research, 14: 601-604.

Clark, L. J., Whalley, W. R., and P. B. Barraclough. 2003. How do roots penetrate strong soil? Plant and Soil, 255:93-104.

Coffman, L., Green, R., Clar, M., and S. Bitter. 1994. Development of bioretention practices for stormwater management. In Current practices in modelling the management of stormwater impacts, By William James.

Comas, L. H. and D. M. Eissenstat. 2009. Patterns in root trait variation among 25 coexisting North American forest species. New Phytology, 1-14.

Daddow, R. L., and G. E. Warrington. 1983. Growth-limiting soil bulk densities as influenced by soil texture. WSDG REPORT WSDG-TN-00005, Watershed Systems Development Group, USDA Forest Service, Fort Collins, Colorado. 
Davis, A. P., Hunt et al., W. F., Traver, R. G., and M. Clar. 2009. Bioretention technology: Overview of current practice and future needs. J. Environ. Eng. 135:109-117.

Day, S.D., J. R. Seiler, and N. Persaud. 2000. A comparison of root growth dynamics of silver maple and flowering dogwood in compacted soil at differing soil water contents. Tree Physiol., 20:257-263.

De la Cruz, A., and C. T. Hackney. 1977. Energy value, elemental composition, and productivity of belowground biomass of a Juncus tidal marsh. Ecology 58:651170.

De Sherbiniin, A., A. Rahman, A. Barbieri, J. C. Fotso, and Y. Zhu (Eds.). 2009. Urban population-environment dynamics in the developing world: Case studies and lessons learned. Paris: Committee for International Cooperation in National Research in Demography (CICRED).

Denman, L., P. May, and P. Breen. 2006. An investigation of the potential to use street trees and their root zone soils to remove nitrogen from urban stormwater. Aust. J. Water Resour. 10:303-311.

Devitt, D. A., and S. D. Smith. 2002. Root channel macropores enhance downward movement of water in a Mojave Desert ecosystem. Journal of Arid Environments, 50: 99-108.

Dingman, S. L. 2014. Physical Hydrology. Waveland Pr Inc; $3^{\text {rd }}$ ed., 643 pages.

Disparte, A. A., 1987. Effect of root mass density on infiltration among four Mediterranean dryland forages and two irrigated forage legumes. M.S. Thesis, Univ. of California, Riverside, CA. Q180A494 DH5

Eissenstat, D. M., and R. D. Yanai. 1997. The ecology of root lifespan. Adv. Ecol. Res. $27: 1-62$

Eissenstat, D. M., Wells, C. E., Yanai, R. D., and J. L. Whitbeck. 2000. Building roots in a changing environment: implications for root longevity. New Phytol., 147:33-42.

Emerson, C. H., and R. G. Traver. 2008. Multiyear and seasonal variation of infiltration from storm-water best management practices. Journal of Irrigation and Drainage Engineering, Vol. 134, No. 5.

EPA (Environmental Protection Agency), 1999. Storm water technology fact sheet bioretention. office of water Washington, D.C. EPA 832-F-99-012, September 1999. 
EPA, 2007. Reducing stormwater costs through Low Impact Development (LID) strategies and practices. EPA 841-F-07-006. Nonpoint source control branch (4503T), 1200 Pennsylvania Ave., NW, Washington, DC 20460. https://www.h-gac.com/community/low-impactdevelopment/documents/Reducing-Stormwater-Costs-through-LID.pdf, (Accessed May 2016)

EPA, 2009. Green streets: A conceptual guide to effective green street design solutions. EPA-833-F-09-002, Environmental Protection Agency, Washington, DC. August 2009, www.epa.gov/greeninfrastructure, (Accessed May 2016)

EPA, 2012. National Pollutant Discharge Elimination System (NPDES). Bioretention (Rain gardens). Environmental Protection Agency Washington, DC. http://cfpub.epa.gov/npdes/stormwater/menuofbmps/index.cfm?action=factsheet $\underline{\text { results } \& \text { view }=\text { specific \&bmp }=72 \& \text { minmeasure }=5}$, (Accessed May 2016)

EPA, 2016a. Estimating monetized benefits of groundwater recharge from stormwater retention practices. Environmental Protection Agency, Washington, DC. https://www.epa.gov/green-infrastructure/estimating-monetized-benefitsgroundwater-recharge-stormwater-retention, (Accessed September 2016)

EPA, 2016b. National Pollutant Discharge Elimination System (NPDES). Stormwater discharges from municipal sources, Phase I and II MS4 permits. Environmental Protection Agency, Washington, DC. https://www.epa.gov/npdes/stormwaterdischarges-municipal-sources\#overview, (Accessed May 2016)

Fairfax Co., 2007. Recommended plant list for bioretention facilities, Fairfax County Public Works and Environmental Services, Virginia.

Fischer, C., Roscher, C., Jensen, B., Eisenhauer, N., Baade, J., Attinger, S., Scheu, S., Weisser, W. W., Schumacher, J., and A. Hildebrandt. 2014. How Do Earthworms, Soil Texture and Plant Composition Affect Infiltration along an Experimental Plant Diversity Gradient in Grassland? PLOS, June Vol. 9, Issue 6.

Fitter, A. H., Graves, J. D., Self, G. K., Brown, T. K., Bogie, D. S., and K. Taylor. 1998. Root production, turnover and respiration under two grassland types along an altitudinal gradient: Influence of temperature and solar radiation. Oecologia, 114:20-30.

Foster, J., Lowe, A., and S. Winkelman. 2011. The value of green infrastructure for urban climate adaptation. The Center for Clean Air Policy. www.ccap.org 
Garmestani, A., Clements, J., Pratt, J., and L. Hair. 2012. The economics of green infrastructure and low-impact development practices. In: Economic Incentives for Stormwater Control. CRC Press. 245 pgs.

Ghestem, M., Sidle, R. C., and A. Stokes. 2011. The influence of plant root systems on subsurface flow: Implications for slope stability. BioScience, Vol. 61, No. 11.

Gill, R. A. and R. B. Jackson. 2000. Global patterns of root turnover for terrestrial ecosystems. New Phytologist, Vol. 147, No. 1, Special Issue: Root dynamics and global change: An ecosystem perspective (July, 2000), pp. 13-31.

Gotelli, N. J. and A. M. Ellison. 2004. A primer of ecological statistics. Sinauer Associates, Inc. Publishers, Sunderland, MA.

Greene, A. 2008. Impacts of biota on bioretention cell function during the establishment in the Midwest. Master thesis, Kansas State University, Manhattan, Kansas.

Gregory, P. 2006. Plant roots: Growth, activity and interactions with soils. Blackwell Publishing. Oxford, U.K.

Gomes, A. R. S., and T. T. Kozlowski. 1980. Growth responses and adaptations of Fraxinus pennsylvanica seedlings to flooding. Plant Physiol., 66:267-271.

Hamilton, G. W., and D. V. Waddington. 1999. Infiltration rates on residential lawns in central Pennsylvania. Journal of Soil and Water Conservation. 54.3: p564.

Hatt, B. E., T. D. Fletcher and A. Deletic. 2009. Hydrologic and pollutant removal performance of biofiltration systems at the field scale. Journal of Hydrology, 365(3-4):310-321.

Hawes, M. C., Gunawardena, U., Miyasaka, S., Zhao, X., 2000. The role of root border cells in plant defense. Trends Plant Sci. 5:128-133.

Hemminga, M., A., Huiskes, A. H. L., Steegstra, M., and J. van Soelen. 1996. Assessment of carbon allocation and biomass production in a natural stand of the salt marsh plant Spartina anglica using ${ }^{13} \mathrm{C}$. Marine Ecological Progress Series, Vol. 130:169-178.

Hill, B. H. 1987. Typha productivity in a Texas pond: Implications for energy and nutrient dynamics in freshwater wetlands. Aquatic Botany, 27:385-394.

Hillel, D. 1998. Environmental soil physics. $1^{\text {st }}$ Edition, Academic Press, San Diego. 
Hillel, D. 2007. Soil in the Environment: Crucible of Terrestrial Life. Academic Press; $1^{\text {st }}$ edition.

Hodge, A. 2006. Plastic plants and patchy soils. J. of Experimental Botany, Vol. 57, No. 2:401-411.

Hodge, A., Berta, G., Doussan, C., Merchan, F., and M. Crespi. 2009. Plant root growth, architecture and function. Plant Soil, 321:153-187.

Homer, C., Dewitz, J., Yang, L., Jin, S., Danielson, P., Xian, G., Coulston, J., Herold, N., Wickham, J., and K. Megown. 2015. Completion of the 2011 national land cover database for the conterminous United States-representing a decade of land cover change information. USGS, Photogrammetric engineering and remote sensing.

Hose, E. Clarkson, D. T., Steudle, E., Schreiber, L. and Hartung, W. 2001. The exodermis: a variable apoplastic barrier. Journal of Experimental Botany, 52:2245-2264.

Houle, J. J., Roseen, R. M., D. Ballestero, T. P., Puls, T. A., and J. Sherrard Jr. 2013. Comparison of maintenance cost, labor demands, and system performance for LID and conventional stormwater management. J. Environ. Eng., 139:932-938.

Huck, M. G., Klepper, B., and H. M. Taylor. 1970. Diurnal variations in root diameter. Plant Physiol., 45:529-530.

Hunt, W. F., Davis, A. P., and R. G. Traver. 2012. Meeting hydrologic and water quality goals through targeted bioretention design. J. Environ. Eng., 138:698-707.

Jarvis, N. J. 2007. A review of non-equilibrium water flow and solute transport in soil macropores: principles, controlling factors and consequences for water quality. European Journal of Soil Science, June, 58:523-546.

Joo, J., Lee, J., Kim, J. H., Jun, H., and D. Jo. 2014. Inter-event time definition setting procedure for Urban. Water. 6:45-58.

Kalra, Y. P., and D. G. Maynard. 1994. Methods manual for forest soil and plant analysis. Forestry Canada. Ministry of Supply and Services Canada. Micromedia Ltd. Hull, Quebec.

Keeley, J. E. 1979. Population differentiation along a flood frequency gradient physiological adaptations to flooding in Nyssa sylvatica. Ecological Monographs, 49: 89-108. 
Kirkegaard, J. A., So, H. B., and R.J. Troedson. 1992. The effect of soil strength on the growth of Pigeon pea radicles and seedlings. Plant Soil, 140:65-74.

Kloss, C., Calarusse. C., and N. Stoner. 2006. Rooftops to rivers: Green strategies for controlling stormwater and combined sewer overflows. Natural Resources Defense Council. https://www.nrdc.org/sites/default/files/rooftopstoriversII.pdf (Accessed May 2016)

Kokko, E. G., Volkmar, K. M., Gowen B. E., and T. Entz. 1993. Determination of total root surface area in soil core samples by image analysis. Soil \& Tillage Research, 26:33-43.

Lado, M., Paz, A., and M. Ben-Hur. 2004. Organic matter and aggregate size interactions in infiltration, seal formation, and soil loss. Soil Sci. Soc. Am. J. 68:935-942.

Lange, B., Luescher, P., and P. F. Germann. 2009. Significance of tree roots for preferential infiltration in stagnic soils. Hydrol. Earth Syst. Sci., 13:1809-1821.

Lai, J., and L. Ren. 2007. Assessing the size dependency of measured hydraulic conductivity using double-ring infiltrometers and numerical simulation. Soil Physics, Volume 71: Number 6.

Le Coustumer, S., Fletcher, T. D., Deletic, A., Barraud, S., and P. Poelsma. 2012. The influence of design parameters on clogging of stormwater biofilters: A large-scale column study. Water Research, 46:6743-6752.

Lesikar, B. J. 2001. Sealing ponds and lakes with bentonite. Texas A\&M University, Department of Agriculture and Engineering. http://oaktrust.library.tamu.edu/handle/1969.1/87264 (Accessed May 2016)

Leverett, B., and D. Bertolette. 2015. Measuring guidelines handbook. American Forest. http://www.americanforests.org/wp-content/uploads/2014/12/AF-TreeMeasuring-Guidelines_LR.pdf (Accessed May 2016)

Lewellyn, C., Lyons, C. E., Traver, R. G., F., and B. M. Wadzuk. 2016. Evaluation of seasonal and large storm runoff volume capture of an infiltration green infrastructure system. J. Hydrol. Eng., 21(1):04015047.

Li, P., Li, Z., and K. Lu. 2004. Effect of vegetation types on soil infiltration under simulated rainfall. 13th International Soil Conservation Organization Conference - Brisbane, July 2004 Conserving Soil and Water for Society: Sharing Solutions. 
Lichvar, R.W., D.L. Banks, W.N. Kirchner, and N.C. Melvin. 2016. The national wetland plant list: 2016 wetland ratings. Phytoneuron 2016-30: 1-17. Published 28 April 2016. ISSN $2153733 X$

Lindsey, P., and N. Bassuk. 1991. Specifying soil volumes to meet the water needs of mature urban street trees and trees in containers. Journal of Arboriculture, Vol. $17: 6$.

Livesley, S. J., Stacey, C. L., Gregory, P. J., and R. J. Buresh. 1999. Sieve size effects on root length and biomass measurements of maize (Zeamays) and Grevillea robusta. Plant and Soil 207:183-193.

Lyford, F. P., and H. K. Qashu. 1969. Infiltrations as affected by desert vegetation. Water Resources Research. 5:1373-1376.

Lynch, J. 1995. Root architecture and plant productivity. Plant Physiol., 109:7-13.

MacDonagh, P. 2011. The urban forest is broken: How we can enhance 1,000,000 tree initiatives to meet stormwater goals. In low impact development technology design methods and case studies, American Society of Civil Engineers, Reston, Virginia.

MacDonagh, P. 2015. The state of the science using urban trees for stormwater management. In $12^{\text {th }}$ Annual Water Conservation Showcase, San Francisco, CA.

Martens, D. A. 2002. Relationship between plant phenolic acids released during soil mineralization and aggregate stabilization. Soil Sci. Soc. Am. J., 66:1857-1867.

Massman, J. W., and C. D. Butchart. 2001. Infiltration characteristics, performance, and design of stormwater facilities. Interim Report. Research Project Agreement No. T1803, Task 12, Department of Civil and Environmental Engineering, University of Washington.

Materechera, S. A., Dexter, A. R., and A. M. Alston. 1991. Penetration of very strong soils by seedling roots of different plant species. Plant and Soil. Vol 135, Issue $1: 31-41$.

Mitchel, A. R., Ellsworth, T. R., and B. D. Meek. 1995. Effect of root systems on preferential flow in swelling soil. Commun. Soil Sci. Plant Anal., 26(15\&16), 2655-2666.

Meek, B. D., Rechel, E. R., Carter, L. M., DeTar, W. R., and A. L. Urie. 1992. Infiltration rate of a sandy loam soil: Effects of traffic, tillage, and plant roots. Soil Sci. Soc. Am. J., 56:908-913. 
Merkel, W. H., Moody, H. F., and Q. D. Quan. 2016. Design rainfall distribution based on NOAA atlas 14 rainfall depths and durations. United States Department of Agriculture, Natural Resources Conservation Service.

Meuleman, A. F. M., Beekman, J. P. and J. T. A. Verhoeven. 2002. Nutrient retention and nutrient-use efficiency in Phragmites australis stands after wastewater application. Wetlands, Vol. 22, No. 4:712-721.

Montagnoli, A., Di Iorio, A. Terzaghi, M., Trupiano, D., Scippa, G. S., and Chiatante D. 2014. Influence of soil temperature and water content on fine-root seasonal growth of European beech natural forest in Southern Alps, Italy. Eur. J. Forest Res., 133:957-968.

Moore, T. L. 2011. Assessment of ecosystem service provision by stormwater control measures. Ph.D. dissertation. North Carolina State University, Raleigh, North Carolina.

Mote, P. W., and E. P. Salathé Jr. 2010. Future climate in the Pacific Northwest. Climatic Change 102:29-50.

Nassif, S. H., and E. M. Wilson. 1975. The influence of slope and rain intensity on runoff and infiltration. Hydrological Sciences Bulletin, 20:539-553.

Nowak, D. J., and E. J. Greenfield. 2012. Tree and impervious cover change in U.S. cities. Urban Forestry \& Urban Greening. 11:21-30.

NRCS, 2012. Soil infiltration: Soil quality kit- guides for educators. United State Department of Agriculture, Natural Resource Conservation Service. Published May, 2012.

Odong, J.. 2013. Evaluation of empirical formulae for determination of hydraulic conductivity based on grain-size analysis. International Journal of Agr. \& Env., 18 .

Olney, E., Stevens, H., and T. Kurts. 2010. A pilot study investigating root structure in green street bioswales in Portland, Oregon. City of Portland Bureau of Environmental Services. Sustainable Stormwater Division.

Olson, N. C., Gulliver, J. S., Nieber, J. L., and M. Kayhanian. 2013. Remediation to improve infiltration into compact soils. Journal of Environmental Management, 117:85-95. 
ORDEQ, 2016. Permit evaluation report and fact sheet for National Pollution Discharge Elimination System Permit phase II Municipal Separate Storm Sewer System (MS4) stormwater discharges. Oregon Department of Environmental Quality, Portland, OR 97204.

Ostonen, I. Püttsepp, Ü., Biel, C., Alberton, O., Bakker, M. R., Lõhmus, K., Majdi, H., Metcalfe, D., Olsthoorn, A. F.M., Pronk, A., Vanguelova, E., Weih M., and I. Brunner. 2007. Specific root length as an indicator of environmental Change. Plant Biosystems, Vol. 141, No. 3:426-442.

Packham, J. R., Harding, D. J., and G. M. Hilton. 1992. In Functional Ecology of Woodlands and Forests. Spring publishing, New York, NY.

Peng, X., and R. Horn, 2013. Identifying six types of soil shrinkage curves from a large set of experimental data. Soil Sci. Soc. Am. J., 77:372-381.

Pitt, R., Chen, S., and S. Clark. 2002. Compacted urban soils effects on infiltration and bioretention stormwater control designs. Presented at the 9th International Conference on Urban Drainage. IAHR, IWA, EWRI, and ASCE. Portland, Oregon, September 8-13, 2002.

Pitt, R., Chen, S., Clark, S. E., Swenson, J., and C. K. Ong. 2008. Compaction's impacts on urban storm-water infiltration. J. Irrig. Drain Eng. 134:652-658.

Place, G. T. 2006. Effects of high bulk density soil layers on root distribution, resource acquisition and root morphology of soybean (Glycine max), Sicklepod (Senna obtusifolia) and palmer amaranth (Amaranthus palmeri). Thesis, North Carolina State University, Raleigh, NC.

Pregitzer, K. S., King, J. S., Burton. A. J., and S. E. Brown. 2000. Responses of tree fine roots to temperature. New Phytol., 147:105-115.

Rasse, D. P., Smucker, A. J. M., \& Santos, D. 2000. Alfalfa root and shoot mulching effects on soil hydraulic properties and aggregation. Soil Science Society of America Journal, 64, 2:725-731.

Read, J., Fletcher, T. D., Wevill, T., and A. Deletic. 2010. Plant traits that enhance pollutant removal from stormwater in biofiltration systems. International Journal of Phytoremediation, 12:34-53.

Read, J., Wevill, T., Fletcher, T. D., and A. Deletic. 2008. Variation among plant species in pollutant removal from stormwater in biofiltration systems. Water Research, 42:893-902. 
Reubens, B., J. Poesen, F. d. Danjon, G. Geudens, and B. Muys. 2007. The role of fine and coarse roots in shallow slope stability and soil erosion control with a focus on root system architecture: a review. Trees, 21:385-402.

Rodgers, H. L., Day, F. P., and R. B. Atkinson. 2003. Fine root dynamics in two Atlantic White-Cedar wetland with contrasting hydroperiods. WETLANDS, Vol. 23, No. 4, pp. 941-949.

Roy-Poirier, A., Champagne, P., and Y. Filion. 2010. Review of bioretention system research and design: past, present, and future. Journal of Environmental Engineering, Vol. 136, No. 9:878-889.

Saxton, K. E., W. J. Rawls. 2006. Soil water characteristic estimates by texture and organic matter for hydrologic solutions. Soil Sci. Soc. Am. J., 70:1569-1578

Scharenbroch, B. C., Morgenroth, J., and B. Maule. 2016. Tree species suitability to bioswales and impact on the urban water budget. Journal of Environmental Quality, 45: 1: 199-206.

Scheyer, J. M., and K. W. Hipple. 2005. Urban soil primer. United States Department of Agriculture, Natural Resources Conservation Service, National Soil Survey Center, Lincoln, Nebraska (http://soils.usda.gov/use).

Schueler, T., 1994. The importance of imperviousness. Watershed Protection Techniques, 1(3):100-111.

Selbig, W. R. and N. Balster. 2009. Evaluation of turf-grass and prairie-vegetated precipitation gardens in a clay and sand soil, Madison, Wisconsin, Water Years 2004-08. U.S. Geological Survey. Scientific Investigations Report 2010-5077. http://pubs.usgs.gov/sir/2010/5077/pdf/sir20105077.pdf (Accessed May 2016)

Smit, A. L. 2000. Root methods. A handbook. Springer-Verlag. Berlin Heidelberg.

Smith, C. S., Michael, S. A., and T. D. Gustafson. 1988. The importance of belowground mineral element stores in Cattails (Typha latifolia). Aquatic Botany, 30:343-352.

Snyder, D.T., 2008. Estimated depth to ground water and configuration of the water table in the Portland, Oregon area: U.S. Geological Survey Scientific Investigations Report 2008-5059, 40 p. http://pubs.usgs.gov/sir/2008/5059/ (Accessed May 2016) 
Spromberg, J. A., Baldwin, D. H., Damm, S. E., McIntyre, J. K., Huff, M., Sloan, C. A., Anulacion, B. F., Davis, J. W., and N. L. Scholz. 2016. Coho salmon spawner mortality in western US urban watersheds: bioinfiltration prevents lethal storm water impacts. Journal of Applied Ecology. 53: 398-407.

Stander, E. K., Borst, M., O'Connor, T. P., and A. A. Rowe. 2010. The effects of precipitation garden size on hydrologic performance. Proceedings of the World Environmental and Water Resources Congress 2010, Providence, Rhode Island, USA, 16-20 May, 2010.

Stevens, H. 2013. City of Portland Bureau of Environmental Services. Personal communication.

SWMM 2014. City of Portland Bureau of Environmental Service Stormwater Management Manual (SWMM). https://www.portlandoregon.gov/bes/64040 (Accessed May 2016)

Thompson, S. E., Harman, C. J., Heine, P., and G. G. Katul. 2010. Vegetation-infiltration relationships across climatic and soil type gradients. Geophysical Research. Vol. 115:1-12.

Triplett, G. B., D. M. Van Doren, and B. L. Schmidt. 1968. Effect of corn (Zea mays L.) stover mulch on no-tillage corn yield and water infiltration. Agron. J. 60:236-239.

Tufekcioglu, A., Raich, J. W., Isenhart, T. M., and R. C. Schultz. 1999. Fine root dynamics, coarse root biomass, root distribution, and soil respiration in a multispecies riparian buffer in Central Iowa, USA. Agroforestry Systems, 44:163-174.

UNC, 2013. Utility notification center. http://www.callbeforeyoudig.org (Accessed May 2016)

USDA, 2016. Predicting the unpredictable: Potential climate change impacts on vegetation in the Pacific Northwest. U.S. Department of Agriculture Pacific Northwest Research Station. Issue 184, April, 2016.

USGS, 2015. HYDRA City of Portland HYDRA rainfall network. http://or.water.usgs.gov/precip/precipitationgage_info/clickmap.html (Accessed May 2016)

Valiela, I., Teal, J. M., and N. Y. Persson. 1976. Production and dynamics of experimentally enriched salt marsh vegetation: Belowground biomass. Limnology and Oceanography, 245, Vol. 21(2). 
Van Der Valk, A. G., and C. B. Davis. 1978. The role of seed banks in the vegetation dynamics of prairie glacial marshes. Ecology, 59:2, pp. 322-335.

Visser, E.J. W., Bogemann, G. M., Van De Steeg, H. M., Pierik, R., and C. W. P. M. Blom. 2000. Flooding tolerance of Carex species in relation to field distribution and aerenchyma formation. New Phytologist, 148:93-103.

Visser, E. J. W. and G. M. Bögemann. 2006. Aerenchyma formation in the wetland plant Juncus effusus is independent of ethylene. New Phytologist, 171:305-314.

Vukovic, M., and A. Soro, 1992. Determination of hydraulic conductivity of porous media from grain-size composition. Water Resources Publications, Littleton, Colorado.

WADOE, 2016. Low Impact Development resources. Municipal Stormwater, Washington State Department of Ecology, http://www.ecy.wa.gov/programs/wq/stormwater/municipal/LID/Resources.html (Accessed Sept 2016)

Wetzel, R. G., and M. J. Howe. 1999. High production in an herbaceous perennial plant achieved by continuous growth and synchronized population dynamics. Aquatic Botany 64:111-129.

Withington, J. M., Reich, P. B., Oleksyn, J., and D. M. Eissenstat. 2006. Comparison of structure and life span in roots and leaves among temperate trees. Ecol. Monogr. 76:381-397.

Wossink, A., and B. Hunt. 2003. The economics of structural stormwater BMPs in North Carolina, WRRI Research Report Number 344. Also available at http://www.agecon.ncsu.edu/faculty/wossink/outreach.html.

Wossink, A., and B. Hunt. 2004. The evaluation of cost and benefits of structural stormwater best management practices in North Carolina, Published by North Carolina Cooperative Extension Service,

Yeakley, J. A., Mass-Hebner, K. G., and R. M. Hughes. 2014. Wild salmonids in the urbanizing pacific northwest. Springer, New York. 271 pages.

Yeakley, J. A., and S. Dunham. 2014. Watershed and landscape scale actions for mitigating impacts on urban salmonids. In: J. A. Yeakley, K. G. Mass-Hebner, R. M. Hughes (eds.) Wild salmonids in the urbanizing Pacific Northwest. Springer, New York, pp 227-241. 
Zedler, J. 2007. Biomass allocation of 40 wetland plants and predictions of functioning in stormwater management research facilities. Botany 670 Class. 2007. Biomass allocation of 40 wetland plants and predictions of functioning in stormwater management research facilities. University of Wisconsin-Madison. http://www.botany.wisc.edu/zedler/images/Leaflet_15_jan_17.pdf (Accessed May 2016)

Zhou, Z. C., and Z. P. Shangguan. 2007. The effects of Ryegrass roots and shoots on loess erosion under simulated rainfall. Catena 70:350-355.

Zhou, Z. C., and Z. P. Shangguan. 2008. Effects of ryegrass soil runoff and sediment control. Catena pedosphere. 18(1):131-136. 


\section{Appendices}

Appendix A: Criteria for selection of 10 Juncus stormwater bioretention facilities. These include installation, vegetation, root, soil, and other environmental characteristic categories. For each category averages, ranges, and associated citations are included.

\begin{tabular}{|c|c|c|c|c|}
\hline Category & Criteria & Average & Range & Citation \\
\hline \multirow{6}{*}{$\begin{array}{l}\text { Facility } \\
\text { installation }\end{array}$} & $\begin{array}{l}\text { Facility size }<1 \text { standard deviation from mean } \\
\text { of inner SE Portland }\left(11-39 \mathrm{~m}^{2}, 31 \mathrm{~m}^{2}\right)\end{array}$ & $18.9 \mathrm{~m}^{2}$ & $12.4-26 \mathrm{~m}^{2}$ & Hart 2012 Unpublished data \\
\hline & Sizing: $6.5 \%$ Target, $2-15 \%$ Range & $6.6 \%$ & $4.4-10.3 \%$ & SWMM 2014, Stevens 2013 \\
\hline & Bioswale, curb extension facility design & $\checkmark$ & & BES 2014 \\
\hline & No bottom liner (infiltrate to subsoil) & $\checkmark$ & & SWMM 2014 \\
\hline & No utility line within or under facilities & $\checkmark$ & & UNC 2013 \\
\hline & $\begin{array}{l}\text { No large buildings within } 6 \mathrm{~m} \text { in SE, SW, and } \\
\text { South direction from SBF }\end{array}$ & $12.1 \mathrm{~m}$ & $6.1-21.3 \mathrm{~m}$ & \\
\hline \multirow[t]{4}{*}{ Vegetation } & Similar number plant species & 4.1 & 3-5 plant species & \\
\hline & Similar tree species & $\checkmark$ & $\begin{array}{l}\text { Black Tupelo (Nyssa sylvatica), Leprechaun } \\
\text { Ash (Fraxinus pennsylvanica), Imperial } \\
\text { Honeylocust (Gleditsia triacanthos), Canada } \\
\text { Red Chokecherry (Prunus virginiana), } \\
\text { Buckthorn (Rhamnus purshiana), } \\
\text { Jacquemontii Birch (Betula jacquemontii) }\end{array}$ & \\
\hline & Similar understory species & $\checkmark$ & $\begin{array}{l}\text { Blue-Grey Rush (Juncus patens), Dwarf } \\
\text { Heavenly Bamboo (Nandina domestica), } \\
\text { Kelsey Dogwood (Cornus sericea), Soft Rush } \\
\text { (Juncus effusus), Creeping Oregon Grape } \\
\text { (Mahonia repens), Gold flame Spiraea } \\
\text { (Spiraea bumalda), Magic Carpet Spiraea } \\
\text { (Spiraea japonica), Orange Sedge (Carex } \\
\text { testacea), Gold Fountains Sedge (Carex } \\
\text { dolichostachya) }\end{array}$ & \\
\hline & $\begin{array}{l}\% \text { cover J. patens }<3 \text { standard deviations of } \\
\text { mean in inner SE Portland facilities }(0-62 \%, 16 \%\end{array}$ & $50 \%$ & $37-60 \%$ & Hart 2012 Unpublished data \\
\hline Roots & $\begin{array}{l}\text { Large range in root mass density and overlap } \\
\text { with similar studies }\end{array}$ & $0.7 \mathrm{~kg} / \mathrm{m}^{3}$ & $0.4-1.1 \mathrm{~kg} / \mathrm{m}^{3}$ & Bartens et al. 2009, Gregory 2006 \\
\hline \multirow[t]{3}{*}{ Topsoil } & $\begin{array}{l}\text { Bulk density }<3 \text { standard deviations of mean in } \\
\text { inner SE Portland range found in Portland } \\
\text { facilities }\left(0.7-1.5 \mathrm{~g} / \mathrm{cm}^{3}\right) \text { and below values } \\
\text { shown to inhibit root growth }\left(1.80 \mathrm{~g} / \mathrm{cm}^{3} \text { fine }\right.\end{array}$ & 1.2 & $1.1-1.5 \mathrm{~g} / \mathrm{cm}^{3}$ (Fine sandy loam) & $\begin{array}{l}\text { Bowen 1981, Hart } \\
2012 \text { Unpublished data }\end{array}$ \\
\hline & $\%$ clay $11-20 \%$ as found in inner SE Portland & $14 \%$ & $12-18 \%$ & $\begin{array}{l}\text { Kalra and Maynard 2001, Hart } 2012 \\
\text { Unpublished data }\end{array}$ \\
\hline & $\begin{array}{l}\% \text { fines }<3 \text { standard deviations of mean } \% \text { fines } \\
\text { found in inner SE Portland }(0-85 \%, 34 \% \text { avg })\end{array}$ & $38 \%$ & $35-49 \%$ & $\begin{array}{l}\text { Kalra and Maynard 2001, Hart } 2012 \\
\text { Unpublished data }\end{array}$ \\
\hline \multirow[t]{3}{*}{ Subsoil } & $\begin{array}{l}\text { Bulk density }<3 \text { standard deviations of mean in } \\
\text { inner SE Portland facilities }\left(0.9-1.6 \mathrm{~g} / \mathrm{cm}^{3}\right) \text { and } \\
\text { below values shown to inhibit root growth }(1.55 \\
\mathrm{g} / \mathrm{cm}^{3} \text { clay loam) }\end{array}$ & 1.4 & $1.1-1.55 \mathrm{~g} / \mathrm{cm}^{3}$ (Clay loam) & $\begin{array}{l}\text { Bowen 1981, } \\
2012 \text { Unpublished data }\end{array}$ \\
\hline & $\%$ clay $10-44 \%$ as found in inner SE Portland & $26 \%$ & $11-34 \%$ & $\begin{array}{l}\text { Kalra and Maynard 2001, Hart } 2012 \\
\text { Unpublished data }\end{array}$ \\
\hline & $\begin{array}{l}\% \text { fines }<3 \text { standard deviations found in inner } \\
\text { SE Portland facilities (27-100\%, 68\% avg) }\end{array}$ & $75 \%$ & $50-89 \%$ & $\begin{array}{l}\text { Kalra and Maynard 2001, Hart } 2012 \\
\text { Unpublished data }\end{array}$ \\
\hline \multirow[t]{3}{*}{ Other } & $<48 \mathrm{hrs}$ Ponding & $11.5 \mathrm{Hrs}$ & $3.7-20.2 \mathrm{Hrs}$ & Bartens et al. 2009, Gregory 2006 \\
\hline & Minimum inter-event time (MIET) & $15.0 \mathrm{~min}$ & $6.8-28.3 \mathrm{~min}$ & Joo 2014 \\
\hline & $>15 \mathrm{~m}$ Groundwater depth & $40.5 \mathrm{~m}$ & $17.7-45.7 \mathrm{~m}$ & Snyder 2008 \\
\hline
\end{tabular}


Appendix B: Criteria for selection of five Juncus and five Carex stormwater bioretention facilities. These include installation, vegetation, root, soil, and other environmental characteristic categories. For each category averages, ranges, and associated citations are included.

\begin{tabular}{|c|c|c|c|c|c|}
\hline Category & Criteria & $\begin{array}{c}\text { Juncus + Tree } \\
\text { Range and Average }\end{array}$ & $\begin{array}{c}\text { Carex } \\
\text { Range and Average }\end{array}$ & Notes & Citation \\
\hline \multirow{9}{*}{$\begin{array}{l}\text { Facility } \\
\text { installation }\end{array}$} & Facility size $<1$ standard deviation from mean of inner SE & & & & \\
\hline & Portland $\left(11-39 \mathrm{~m}^{2}, 31 \mathrm{~m}^{2}\right)$ & $13.7-18.9,16.2 \mathrm{~m}^{2}$ & $7.4-29.6,16.2 \mathrm{~m}^{2}$ & & Hart 2012 Unpublished data \\
\hline & Sizing: 2-15\% Range, $6.5 \%$ Target & $4.4-9.8,5.8 \%$ & $4.1-6.3,5.1 \%$ & & SWMM 2014, Stevens 2013 \\
\hline & (Sizing = Facility area $\%$ of catchment area) & & & & \\
\hline & Bioswale, curb extension facility design & $\checkmark$ & $\checkmark$ & & BES 2014 \\
\hline & No bottom liner (infiltrate to subsoil) & $\checkmark$ & $\checkmark$ & & SWMM 2014 \\
\hline & No utility line within or under facilities & $\checkmark$ & $\checkmark$ & & UNC 2013 \\
\hline & Facility average age $>3$ years & 3.4-3.6, 3.5 years & 3.0-3.8, 3.3 years & & Selbig and Balster 2009 \\
\hline & $0-6 \%$ Slope (\% rise/run) & $0.1-1.6,0.9 \%$ & $1.0-2.8,1.7 \%$ & & SWMM 2014 \\
\hline \multirow[t]{23}{*}{ Vegetation } & Similar number plant species & $3-5,4.4$ & $3-5,3.8$ & & \\
\hline & \multirow{8}{*}{ Tree species } & Black Tupelo & \multirow{8}{*}{ none } & & \\
\hline & & (Nyssa sylvatica) & & & \\
\hline & & Leprechaun Ash & & & \\
\hline & & (Fraxinus pennsylvanica) & & & \\
\hline & & Imperial Honeylocust & & & \\
\hline & & (Gleditsia triacanthos) & & & \\
\hline & & Canada Red Chokecherry & & & \\
\hline & & (Prunus virginiana) & & & \\
\hline & \multirow{12}{*}{ Understory species } & Blue-Grey Rush & Tufted Hair Grass & & \\
\hline & & (Juncus patens) & (Deschampsia cespitosa) & & \\
\hline & & Kelsey Dogwood & Kelsey Dogwood & & \\
\hline & & (Cornus sericea) & (Cornus sericea) & & \\
\hline & & Soft Rush & Soft Rush & & \\
\hline & & (Juncus effusus) & (Juncus effusus) & & \\
\hline & & Dwarf Heavenly Bamboo & Dwarf Heavenly Bamboo & & \\
\hline & & (Nandina domestica) & (Nandina domestica) & & \\
\hline & & Orange Sedge & Orange Sedge & & \\
\hline & & (Carex testacea) & (Carex testacea) & & \\
\hline & & Gold Fountains Sedge & Gold Fountains Sedge & & \\
\hline & & (Carex dollchostachya) & (Carex dollchostachya) & & \\
\hline & $\begin{array}{l}\% \text { cover of understory plants }<3 \text { standard deviations of } \\
\text { mean in inner SE Portland facilities ( } 0-84 \%, 31 \% \text { avg) }\end{array}$ & $50-62,60 \%$ & $25-80,56 \%$ & & Hart 2012 Unpublished data \\
\hline & Similar plant density (\# plants/facility area) & 2.1-3.1, 2.8 plants $/ \mathrm{m}^{2}$ & 2.0-6.1, 4.3 plants $/ \mathrm{m}^{2}$ & & \\
\hline Roots & $\begin{array}{l}\text { Large range in root mass density and overlap with similar } \\
\text { studies }\end{array}$ & $0.4-1.1,0.6 \mathrm{~kg} / \mathrm{m}^{3}$ & $0.2-0.6,0.4 \mathrm{~kg} / \mathrm{m}^{3}$ & & Bartens et al. 2009, Gregory 2007 \\
\hline \multirow[t]{2}{*}{ Topsoil } & $\begin{array}{l}\text { Similar bulk density and }<3 \text { standard deviations of mean in } \\
\text { inner SE Portland range found in Portland facilities ( } 0.7- \\
1.5 \mathrm{~g} / \mathrm{cm}^{3} \text { ) and below values shown to inhibit root growth } \\
\left(1.80 \mathrm{~g} / \mathrm{cm}^{3} \text { fine sandy loams) }\right.\end{array}$ & $1.1-1.5,1.3 \mathrm{~g} / \mathrm{cm}^{3}$ & $1.0-1.3,1.1 \mathrm{~g} / \mathrm{cm}^{3}$ & Fine sandy loam & $\begin{array}{l}\text { Bowen 1981, } \\
\text { Hart } 2012 \text { Unpublished data }\end{array}$ \\
\hline & $\begin{array}{l}\text { Similar } \% \text { fines and }<3 \text { standard deviations of mean } \% \\
\text { fines found in inner SE Portland (0-85\%, 34\% avg) }\end{array}$ & $35-49,39 \%$ & $35-49,41 \%$ & & $\begin{array}{l}\text { Kalra and Maynard 2001, Hart } \\
2012 \text { Unpublished data }\end{array}$ \\
\hline \multirow[t]{2}{*}{ Subsoil } & $\begin{array}{l}\text { Similar bulk density and }<3 \text { standard deviations of mean in } \\
\text { inner SE Portland facilities }\left(0.9-1.6 \mathrm{~g} / \mathrm{cm}^{3}\right) \text { and below } \\
\text { values shown to inhibit root growth }\left(1.55 \mathrm{~g} / \mathrm{cm}^{3} \text { clay loam }\right)\end{array}$ & $1.3-1.6,1.4 \mathrm{~g} / \mathrm{cm}^{3}$ & $1.3-1.5,1.4 \mathrm{~g} / \mathrm{cm}^{3}$ & Clay loam & $\begin{array}{l}\text { Bowen 1981, } \\
\text { Hart } 2012 \text { Unpublished data }\end{array}$ \\
\hline & $\begin{array}{l}\text { Similar \% fines and }<3 \text { standard deviations found in inner } \\
\text { SE Portland facilities }(27-100 \%, 68 \% \text { avg) }\end{array}$ & $35-49,39 \%$ & $35-49,41 \%$ & & $\begin{array}{l}\text { Kalra and Maynard 2001, Hart } \\
2012 \text { Unpublished data }\end{array}$ \\
\hline \multirow[t]{3}{*}{ Other } & $<48 \mathrm{hrs}$ Ponding & $4-34,16 \mathrm{Hrs}$ & $4-47,21 \mathrm{Hrs}$ & & Bartens 2009, Gregory 2006 \\
\hline & Minimum inter-event time (MIET) & $9.3-16.9,14.2 \mathrm{~min}$ & $5.7-30.3,14.0 \mathrm{~min}$ & & Joo et al. 2014 \\
\hline & $>7 \mathrm{~m}$ Groundwater depth & $43-46,41 \mathrm{~m}$ & $8-43,28 \mathrm{~m}$ & & Snyder 2008 \\
\hline
\end{tabular}


Appendix C: Root mass density (RMD) depth distribution. *Significant difference in RMD between Juncus (top) and Carex (bottom) SBFs for J-F(left) and M-J (right). JSignificant difference in RMD between J-F and M-J within Juncus SBFs.
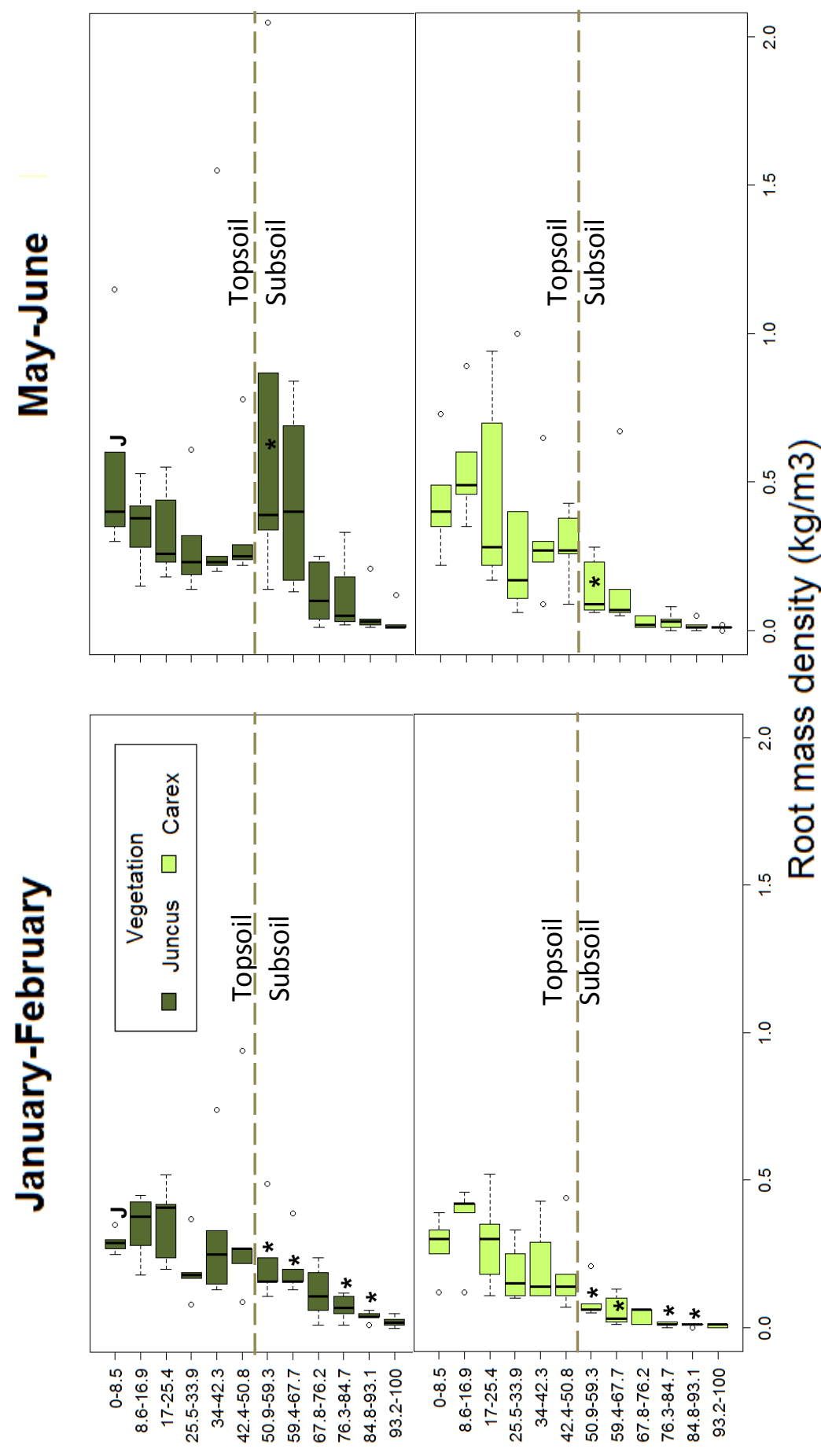

(mo) प7də0 
Appendix D: Stormwater bioretention facility characteristics. "na" indicates not applicable.

\begin{tabular}{|c|c|c|c|c|c|c|c|c|c|}
\hline $\begin{array}{l}\text { Dominant } \\
\text { vegetation }\end{array}$ & Closest intersection & $\begin{array}{l}\text { Age } \\
\text { (yrs) }\end{array}$ & $\begin{array}{l}\text { Slope } \\
\text { (rise/run) }\end{array}$ & $\begin{array}{l}\text { Facility } \\
\text { area } \\
\left(\mathrm{m}^{2}\right)\end{array}$ & $\begin{array}{l}\text { Catchment } \\
\text { area }\left(\mathrm{m}^{2}\right)\end{array}$ & Sizing & $\begin{array}{l}\text { Depth to } \\
\text { groundwater } \\
\text { (m) }\end{array}$ & $\begin{array}{l}\text { Distance to } \\
\text { closest } \\
\text { building (m) }\end{array}$ & $\begin{array}{l}\text { Bldg } \\
\text { direction }\end{array}$ \\
\hline \multirow{12}{*}{ 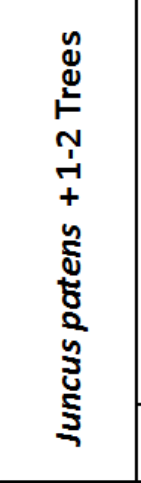 } & SE 45th \& Clay (SW) & 3.5 & $0.8 \%$ & 23.9 & 362.9 & $6.6 \%$ & 42.7 & 6.4 & w \\
\hline & SE 45th \& Clay (NE) & 3.5 & $1.8 \%$ & 22.1 & 213.9 & $10.3 \%$ & 42.7 & 6.7 & $\mathrm{E}$ \\
\hline & SE 46th \& Clay (SW) & 3.5 & $1.8 \%$ & 23.3 & 338.5 & $6.9 \%$ & 42.7 & 6.1 & w \\
\hline & SE 26th \& Grant (NE) & 3.1 & $2.2 \%$ & 26.0 & 585.3 & $4.4 \%$ & 17.7 & 21.3 & $\mathrm{~N}$ \\
\hline & SE 46th \& Clay (2nd Fac South) & 3.5 & $0.1 \%$ & 12.4 & 140.5 & $8.8 \%$ & 42.7 & 7.0 & $\mathrm{E}$ \\
\hline & SE 45th \& Harrison (2nd Fac North) & 3.5 & $0.2 \%$ & 18.9 & 349.2 & $5.4 \%$ & 42.7 & 18.3 & w \\
\hline & SE 46th \& Clay (NE) & 3.5 & $1.6 \%$ & 18.9 & 193.2 & $9.8 \%$ & 42.7 & 15.2 & $E$ \\
\hline & SE 51st \& Salmon (NW) & 3.5 & $0.2 \%$ & 14.7 & 297.3 & $4.9 \%$ & 45.7 & 6.1 & w \\
\hline & SE 45th \& Harrison (1st Fac North) & 3.5 & $0.1 \%$ & 14.7 & 333.9 & $4.4 \%$ & 42.7 & 15.2 & $\mathrm{E}$ \\
\hline & SE 45th \& Clay (SE) & 3.5 & $0.2 \%$ & 13.7 & 299.6 & $4.6 \%$ & 42.7 & 18.3 & $\mathrm{E}$ \\
\hline & Average: & 3.5 & $0.9 \%$ & 18.9 & 311.4 & $6.6 \%$ & 40.5 & 12.1 & $E$ \\
\hline & Standard Deviation: & 0.1 & $0.9 \%$ & 5 & 122 & $0.3 \%$ & 8.1 & 6.2 & na \\
\hline \multirow{7}{*}{$\begin{array}{l}\text { i̊ } \\
\text { đ } \\
\text { ல் }\end{array}$} & SE 27th and Market (NW) & 3.0 & $2.8 \%$ & 9.7 & 234.1 & $4.1 \%$ & 25.9 & 15.2 & w \\
\hline & SE 44th \& Clay (NW) & 3.5 & $1.6 \%$ & 7.4 & 118.9 & $6.3 \%$ & 39.6 & 4.6 & w \\
\hline & SE 18th \& Clinton (South) & 3.0 & $1.6 \%$ & 20.1 & 317.7 & $6.3 \%$ & 8.0 & 6.1 & $\mathrm{~s}$ \\
\hline & SE 55th \& Ankeny ( North) & 3.8 & $1.0 \%$ & 14.2 & 349.3 & $4.1 \%$ & 42.7 & 4.9 & $\mathrm{~N}$ \\
\hline & SE 52nd \& Madison (North) & 3.0 & $1.6 \%$ & 8.0 & 169.0 & $4.7 \%$ & 42.7 & 21.3 & $\mathrm{E}$ \\
\hline & Average: & 3.3 & $1.7 \%$ & 16.2 & 329.6 & $5.1 \%$ & 31.8 & 10.4 & $w$ \\
\hline & Standard Deviation: & 0.4 & $0.7 \%$ & 8.9 & 189.0 & $1.1 \%$ & 13.8 & 7.5 & na \\
\hline
\end{tabular}


Appendix E: Stormwater bioretention facility plant characteristics. "na" indicates not applicable.

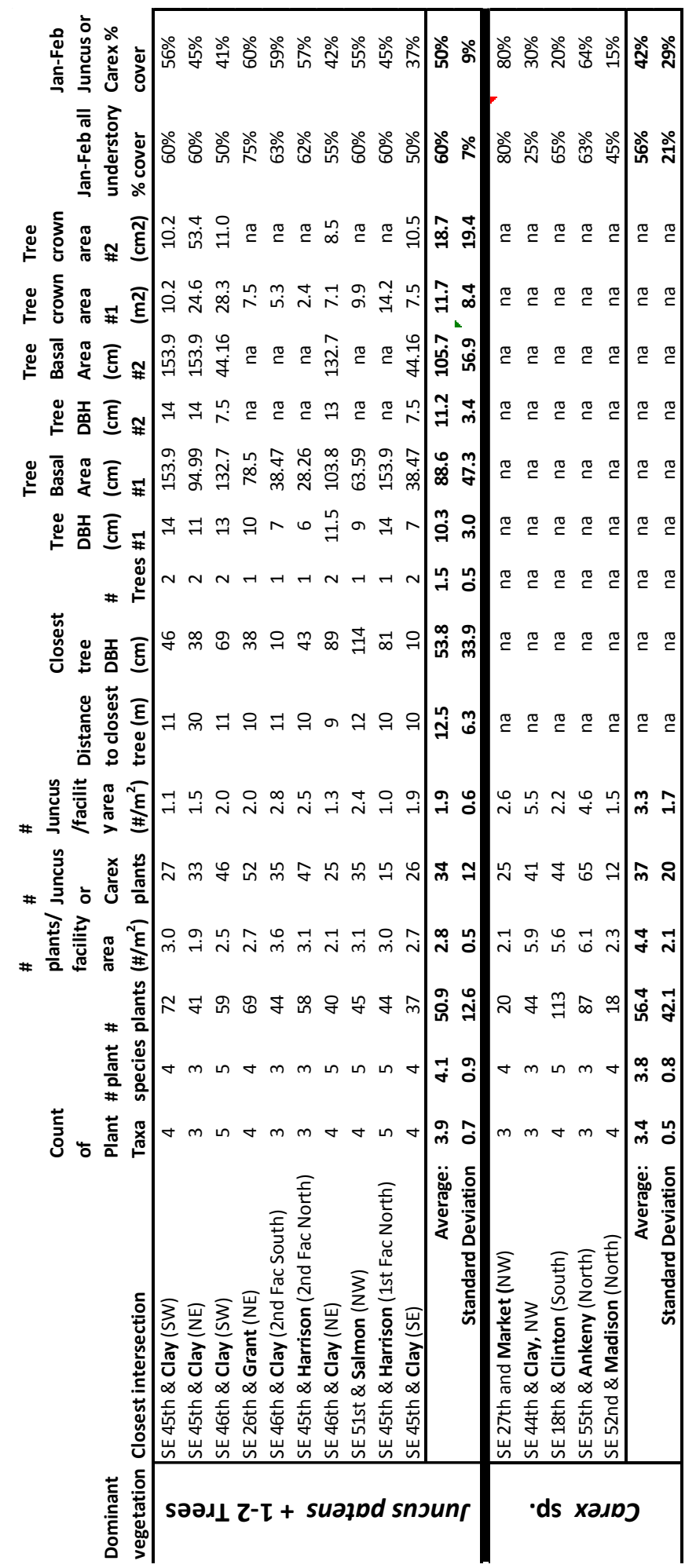


Appendix F: Stormwater bioretention facility soil characteristics.

\begin{tabular}{|c|c|c|c|c|c|c|}
\hline $\begin{array}{l}\text { Dominant } \\
\text { vegetation }\end{array}$ & Closest intersection & $\begin{array}{l}\text { Topsoil } \\
\text { bulk } \\
\text { density } \\
\text { (g/cc) }\end{array}$ & $\begin{array}{l}\text { Subsoil } \\
\text { bulk } \\
\text { density } \\
\text { (g/cc) }\end{array}$ & $\begin{array}{l}\text { Topsoil } \\
\% \text { fines }\end{array}$ & $\begin{array}{l}\text { Subsoil } \\
\% \text { fines } \\
\end{array}$ & $\begin{array}{l}\text { Topsoil } \\
\text { Depth } \\
\text { (cm) } \\
\end{array}$ \\
\hline \multirow{12}{*}{ 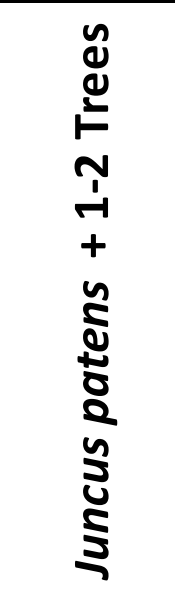 } & SE 45th \& Clay (SW) & 1.26 & 1.39 & 36 & 89 & 56 \\
\hline & SE 45th \& Clay (NE) & 1.07 & 1.16 & 35 & 75 & 52 \\
\hline & SE 46th \& Clay (SW) & 1.3 & 1.47 & 37 & 73 & 33 \\
\hline & SE 26th \& Grant (NE) & 1.36 & 1.58 & 35 & 85 & 38 \\
\hline & SE 46th \& Clay (2nd Fac South) & 1.28 & 1.46 & 41 & 79 & 30 \\
\hline & SE 45th \& Harrison (2nd Fac North) & 1.27 & 1.37 & 35 & 80 & 64 \\
\hline & SE 46th \& Clay (NE) & 1.22 & 1.34 & 35 & 87 & 51 \\
\hline & SE 51st \& Salmon (NW) & 1.13 & 1.55 & 45 & 89 & 43 \\
\hline & SE 45th \& Harrison (1st Fac North) & 1.46 & 1.27 & 49 & 79 & 51 \\
\hline & SE 45th \& Clay (SE) & 1.26 & 1.35 & 39 & 65 & 61 \\
\hline & Average: & 1.3 & 1.4 & 38.7 & 80.1 & 47.9 \\
\hline & Standard Deviation & 0.1 & 0.1 & 4.9 & 7.7 & 11.3 \\
\hline \multirow{7}{*}{$\begin{array}{l}\frac{0}{n} \\
\text { ப் } \\
\text { 巳 }\end{array}$} & SE 27th and Market (NW) & 1.3 & 1.54 & 35 & 80 & 56 \\
\hline & SE 44th \& Clay, NW & 1.17 & 1.27 & 35 & 87 & 43 \\
\hline & SE 18th \& Clinton (South) & 0.95 & 1.48 & 45 & 89 & 56 \\
\hline & SE 55th \& Ankeny (North) & 1.12 & 1.53 & 49 & 79 & 51 \\
\hline & SE 52nd \& Madison (North) & 1.18 & 1.36 & 39 & 46 & 41 \\
\hline & Average: & 1.1 & 1.4 & 40.6 & 76.2 & 49.3 \\
\hline & Standard Deviation & 0.1 & 0.1 & 6.2 & 17.4 & 7.1 \\
\hline
\end{tabular}


Appendix G: Infiltration rates (cm/hr) within stormwater bioretention facilities. "na" indicates when stormwater did not rise above surface of topsoil and thus no infiltration rates were measured.

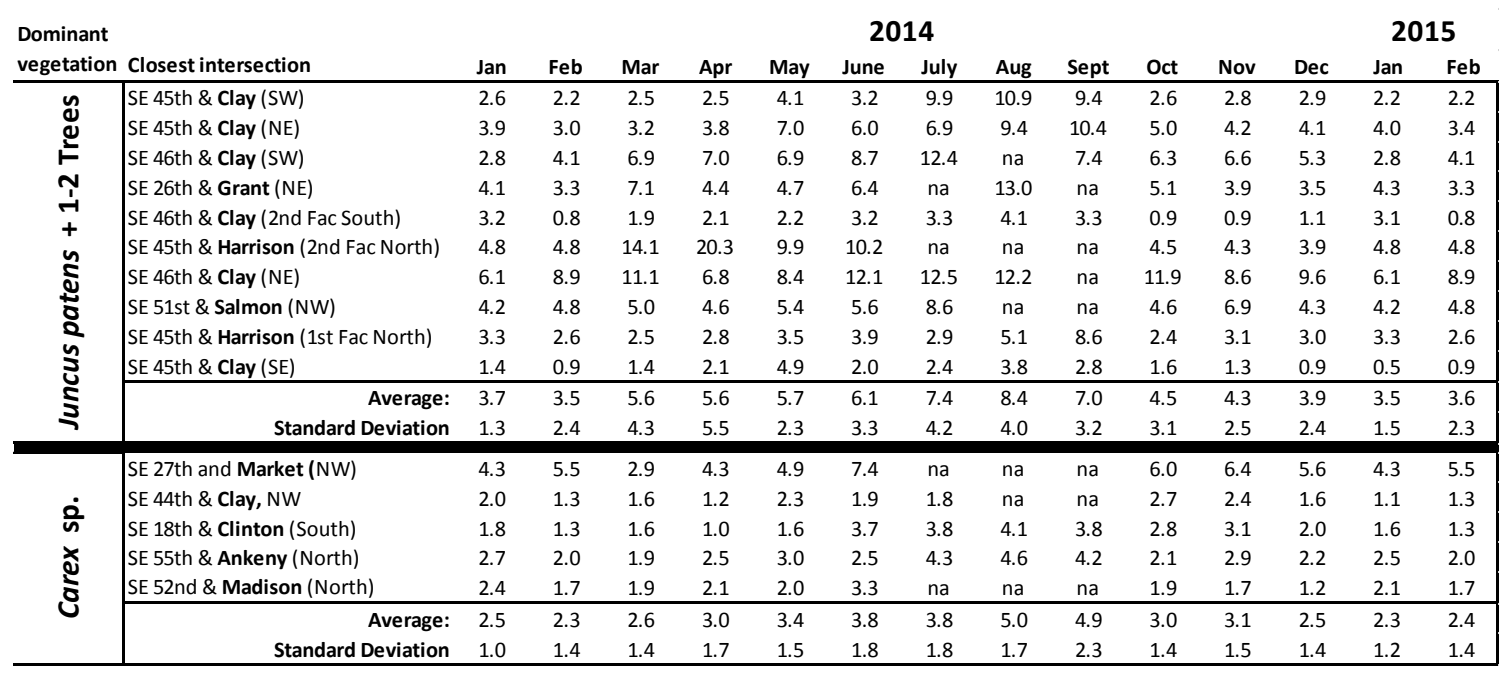

